\title{
قُسّ بن ساعدة الإيادي
}

Quss b. Sāंìda al-Iyādì

Quss b. Sā'ìda al-Iyādì

محمد سعيد

\section{(2) OpenEdition}

\section{Journals}

Édition électronique

URL : https://journals.openedition.org/beo/555

DOI : $10.4000 /$ beo.555

ISBN : 978-2-35159-335-6

ISSN : 2077-4079

\section{Éditeur}

Presses de l'Institut français du Proche-Orient

\section{Édition imprimée}

Date de publication : 1 mai 2012

Pagination : 67-112

ISBN : 978-2-35159-193-2

ISSN : 0253-1623

Référence électronique

" قُسّ بن ساعدة الإيادي "سعيدمحمد , Bulletin d'études orientales [En ligne], Tome LX | mai 2012, mis en ligne le 31 mai 2012, consulté le 21 septembre 2021. URL : http://journals.openedition.org/beo/555 ; DOl : https://doi.org/10.4000/beo.555 


\section{قُسّ بن ساعدة الإيادي}

محمد سعيد

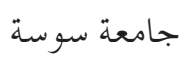

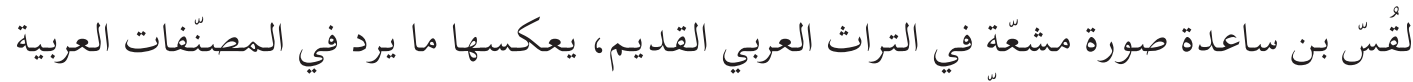

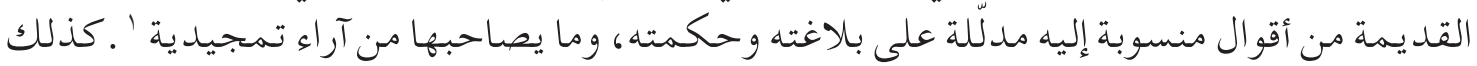

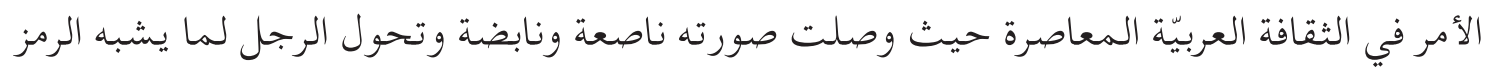

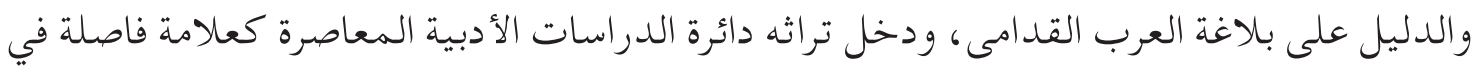
تاريخ اللغة العربية وآدابها.

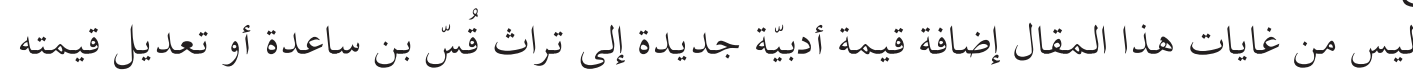

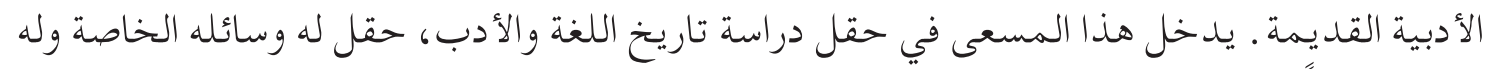

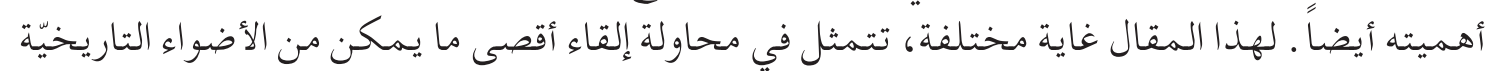

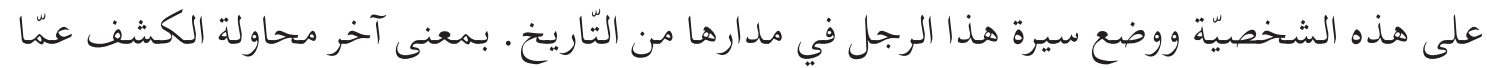

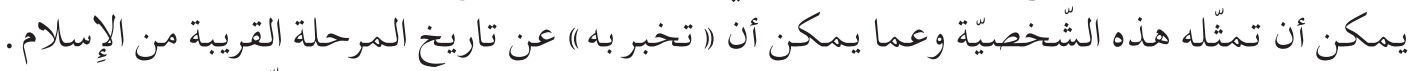

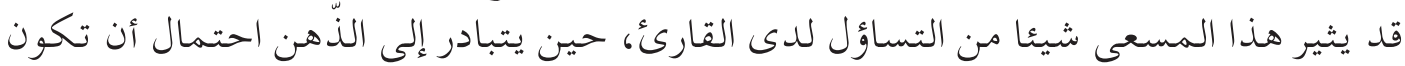

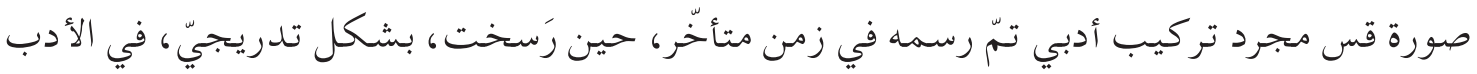

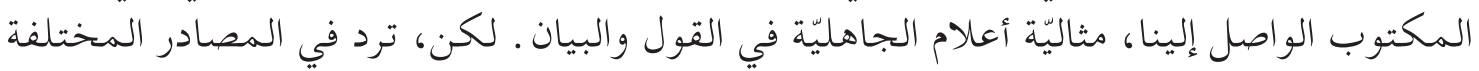

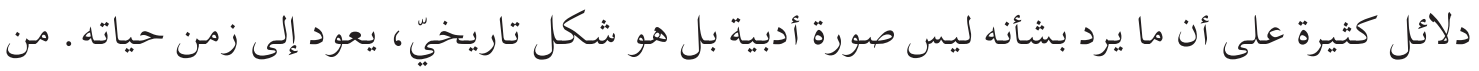

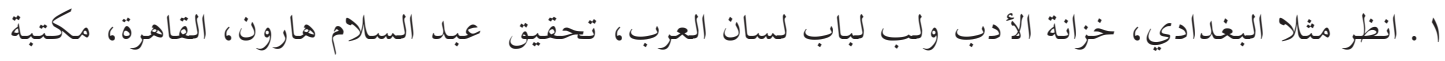

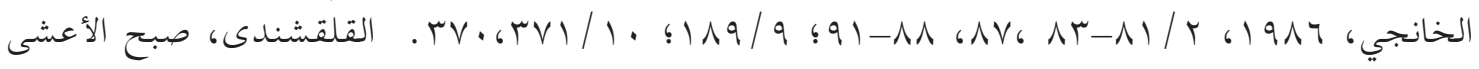

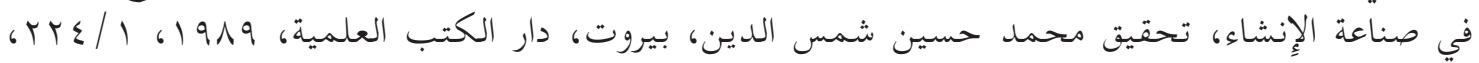

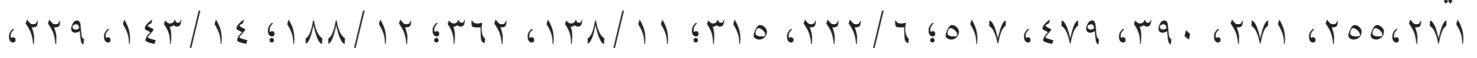

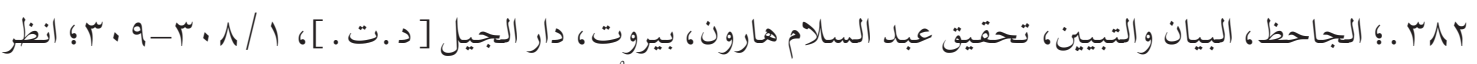

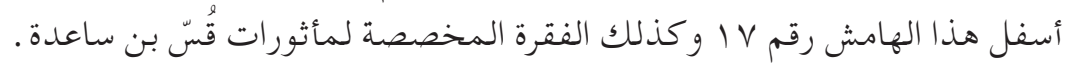


هذه الأدلة ما يأتينا من أفواه معاصريه . يقول الرسول محمّد إنه يعرفه، ورآه يخطب في عكاظ، راكبا

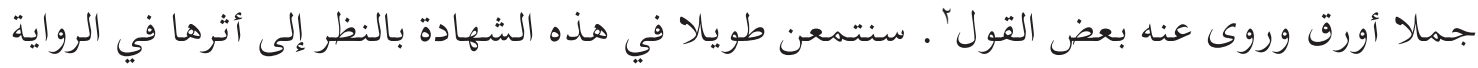

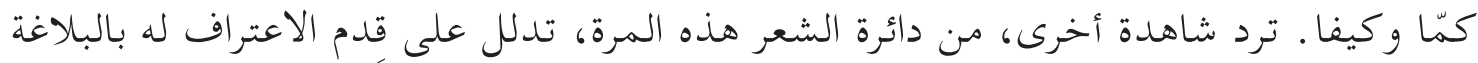

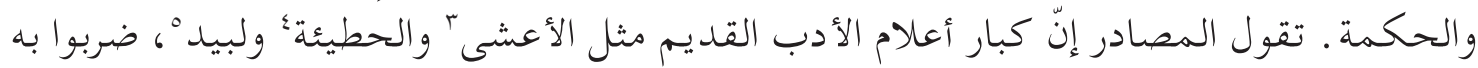

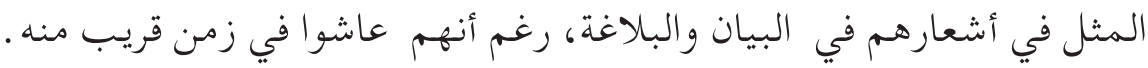

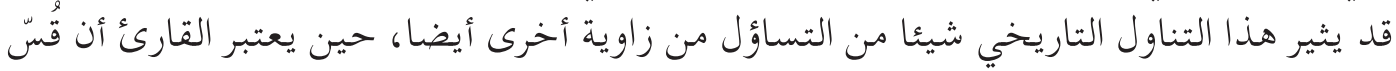

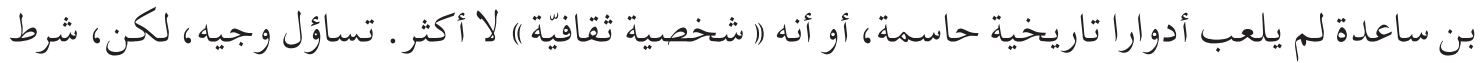

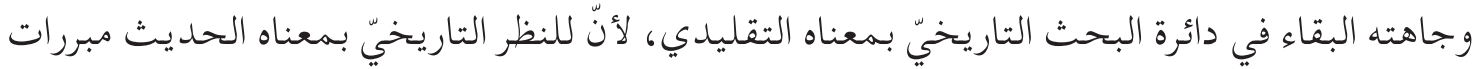

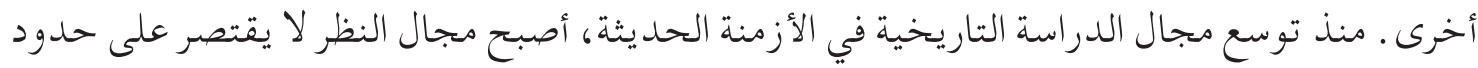

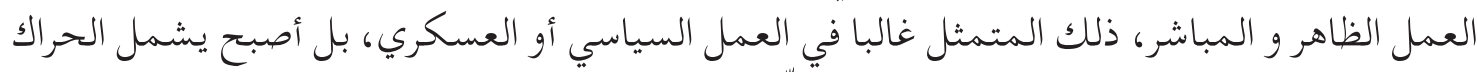

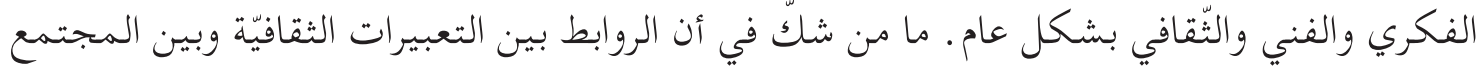

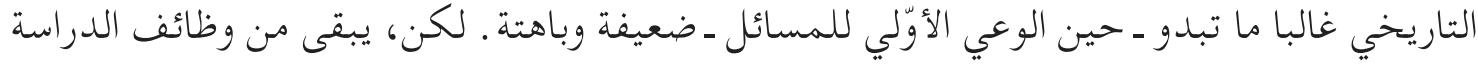

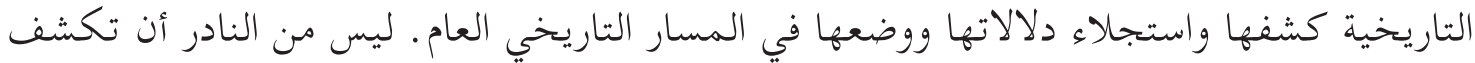

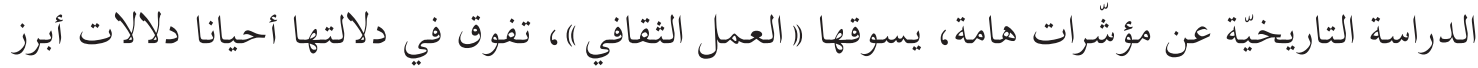

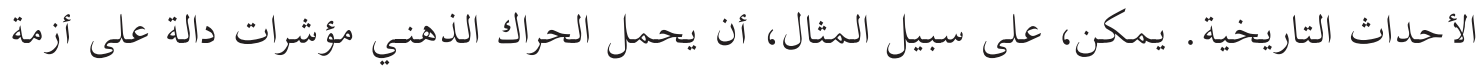

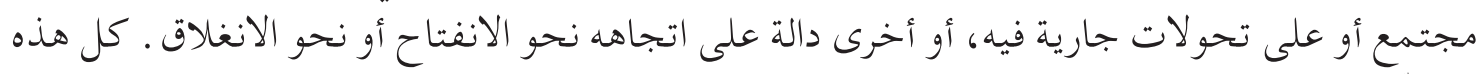

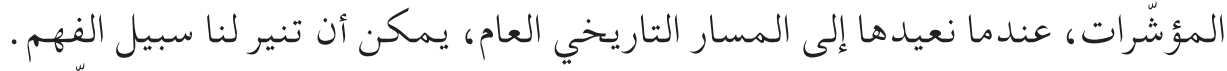

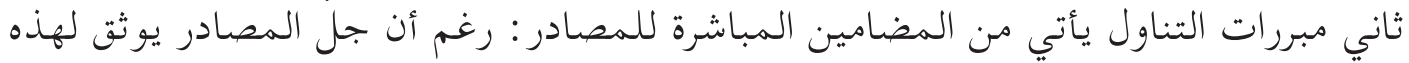

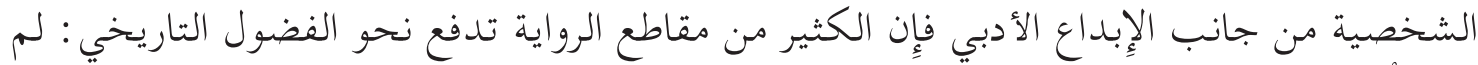

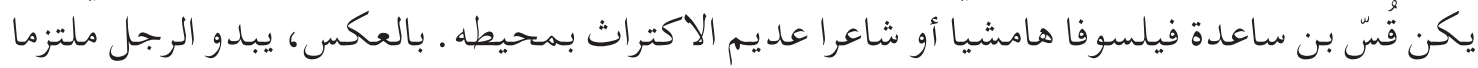

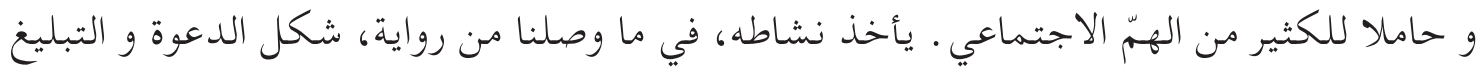

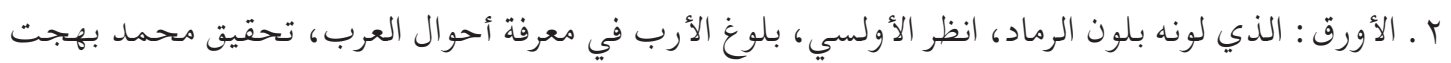

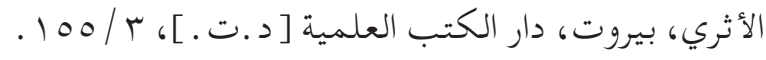

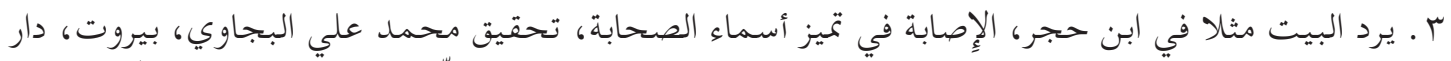

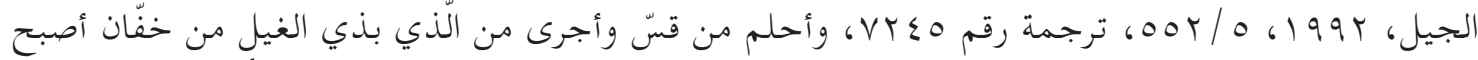

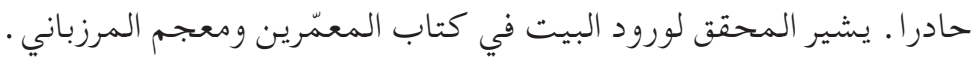

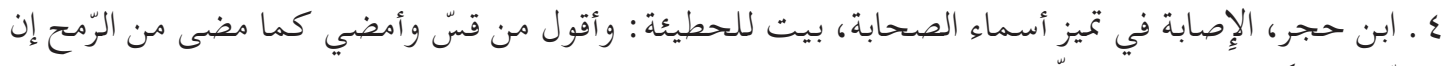

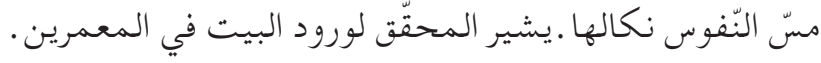

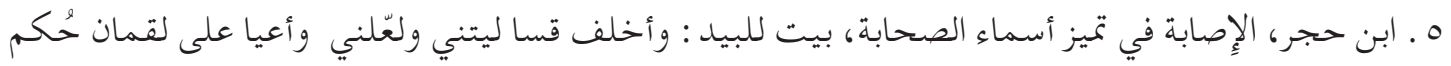

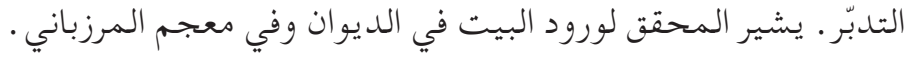




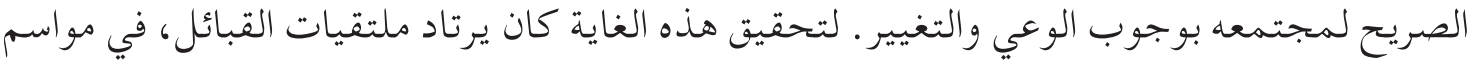

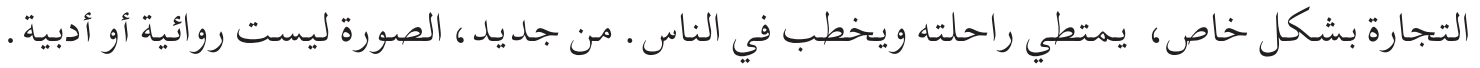

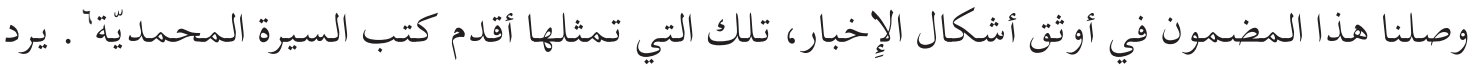

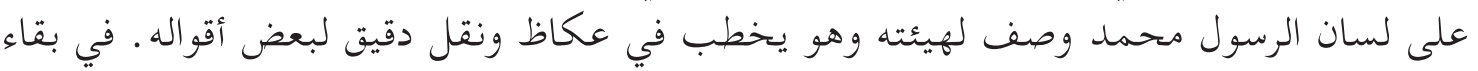

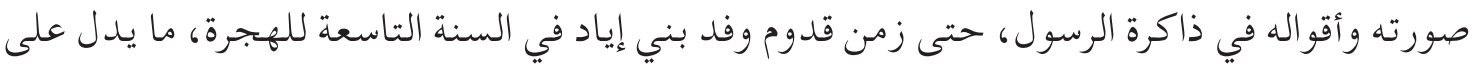

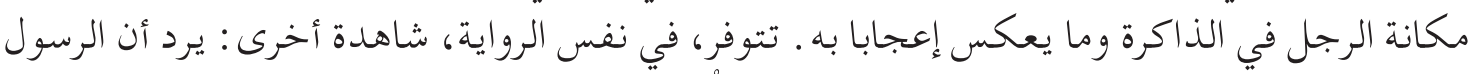

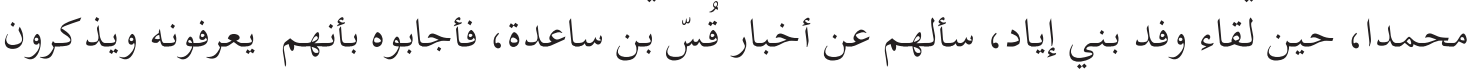

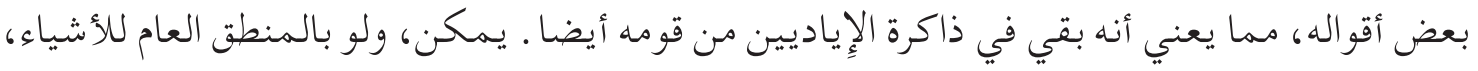

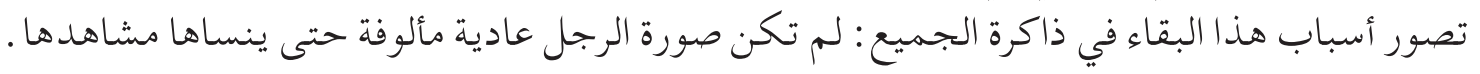

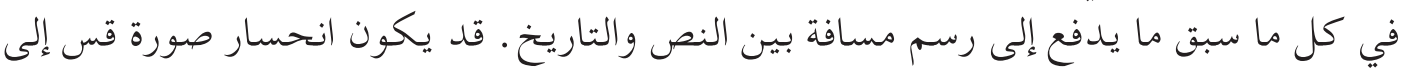

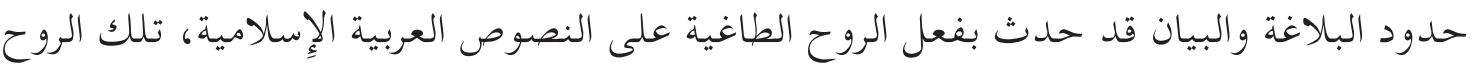

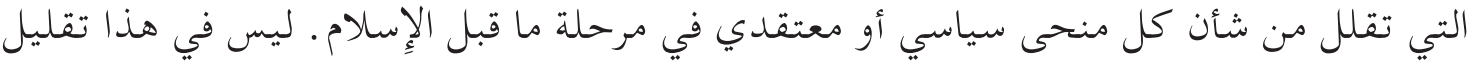

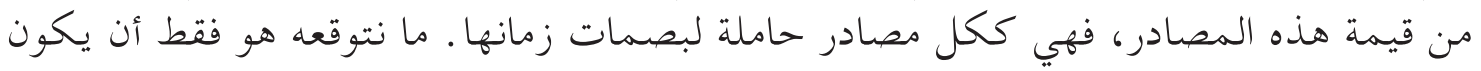

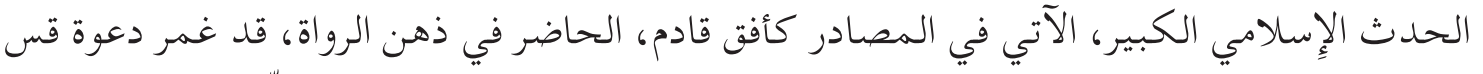

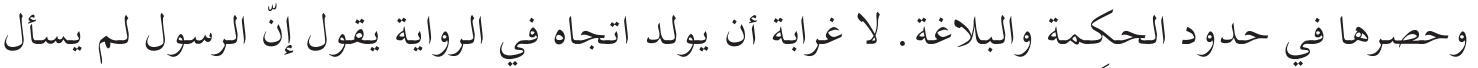

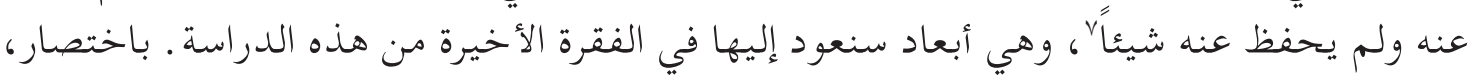

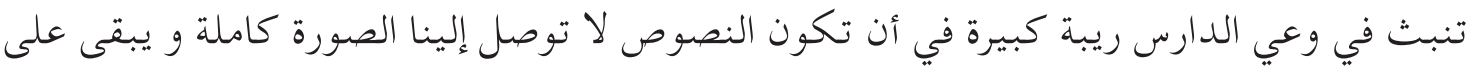

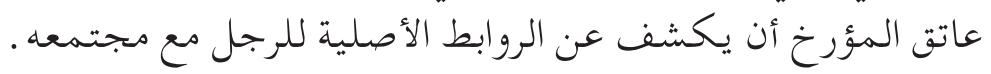

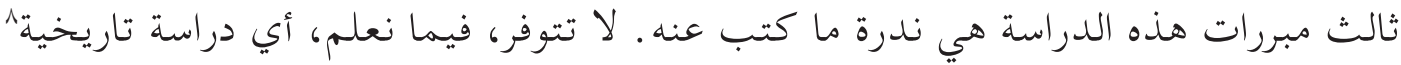

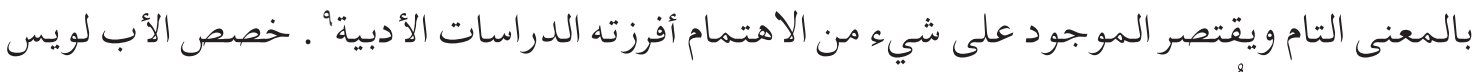

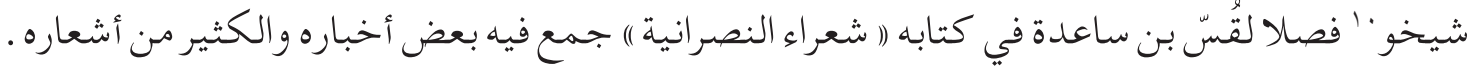

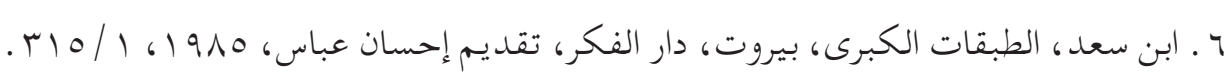
V . انظر أسفل هذا، الفقرة الأخيرة المتعلقة بمنطق الرواية.

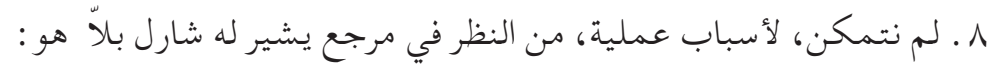

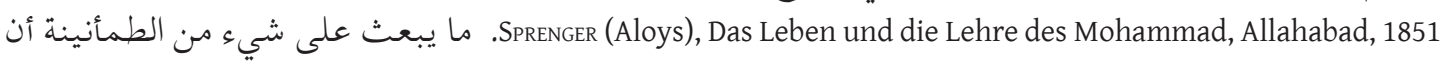
نتائج هذا البحث مضمّّنة فيما كتبه شارل بلا.

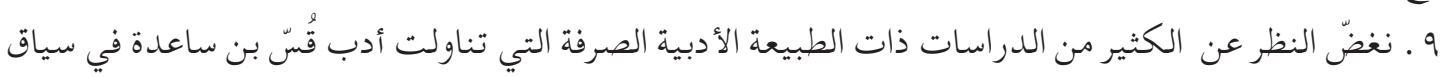

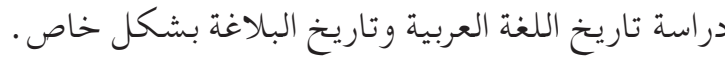

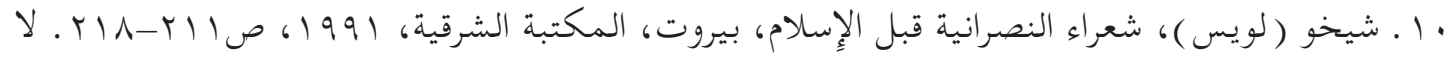

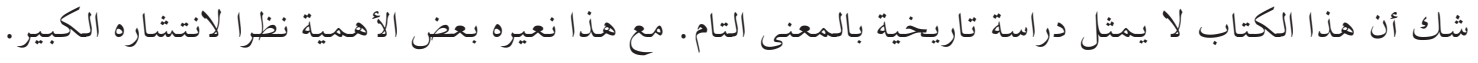


لكن، ليس لهذه الدراسة، القديمة زمنا، طبيعة تاريخية . ما كان يشغل لويس شيخو هو جمع آثار

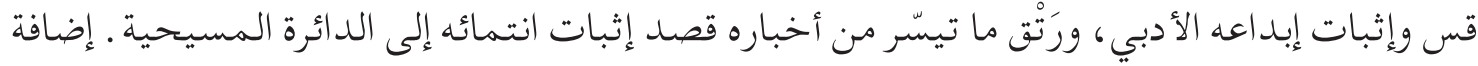

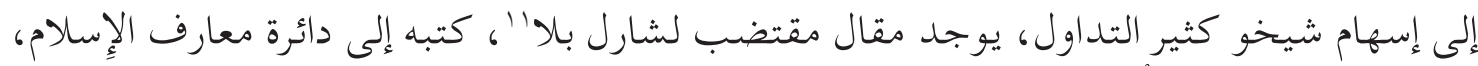

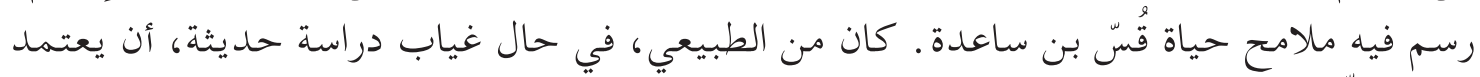

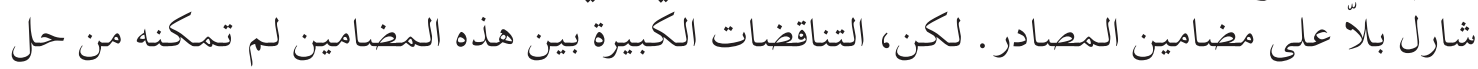

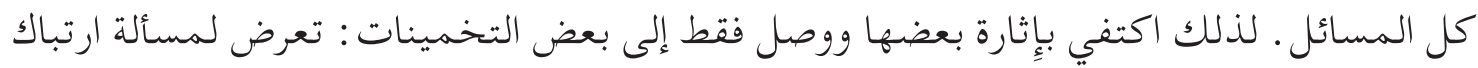
المصادر في شأن نسبته و خلص إلى ترجيح نسبة دون أخرى ـ أثار مسألة انتماء قس بـ إلى دائى دائرة التوحيد

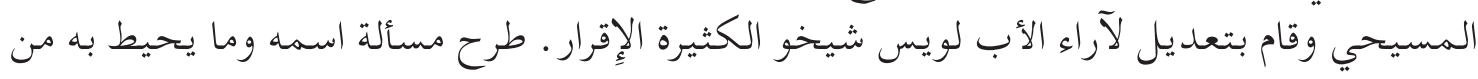

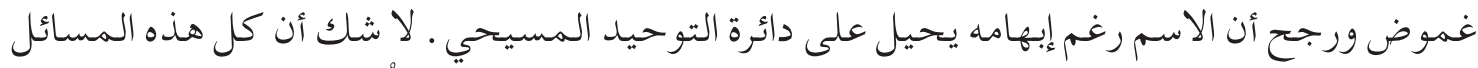

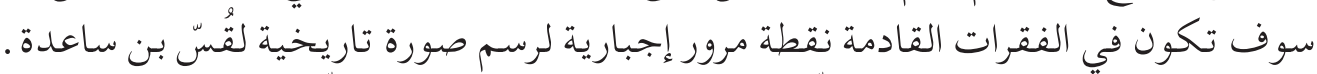

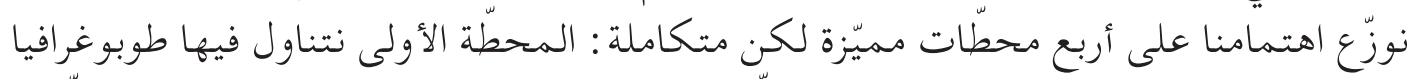

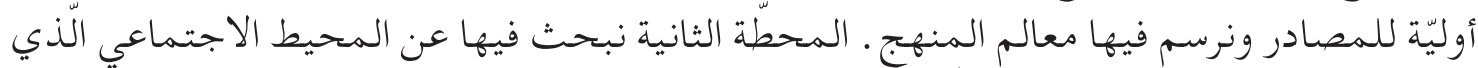

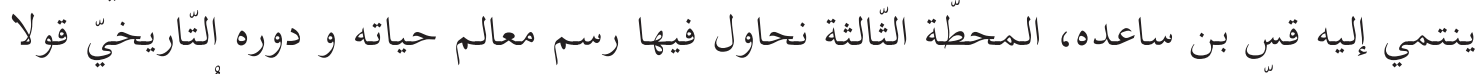

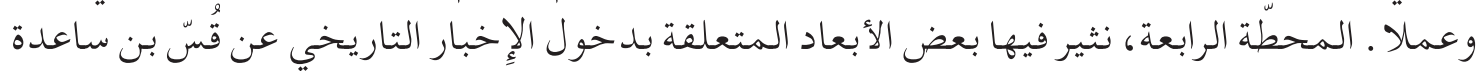

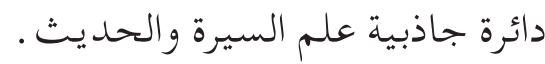

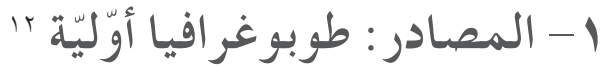

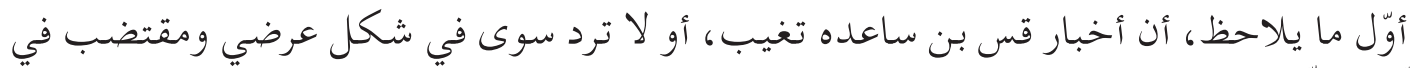

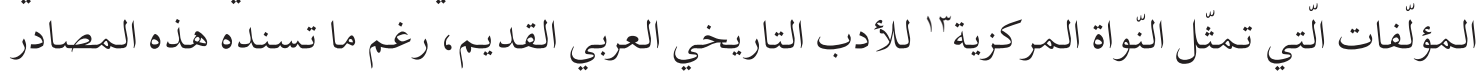

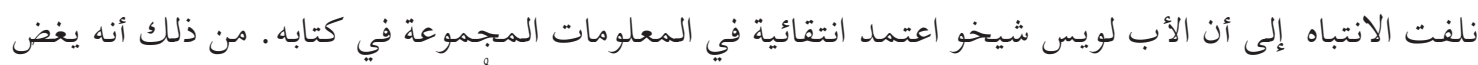

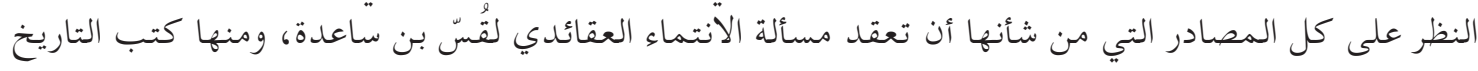

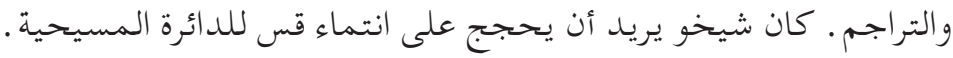

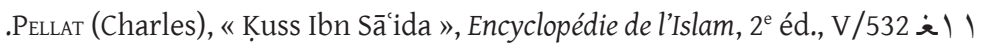

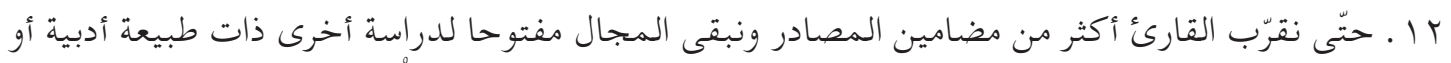

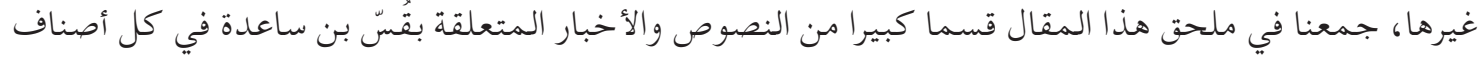

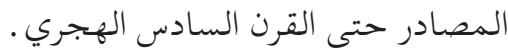

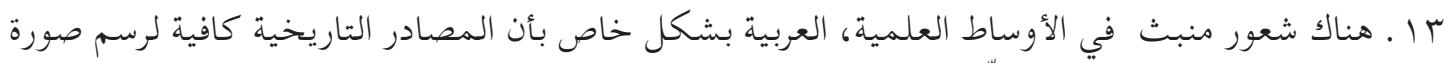

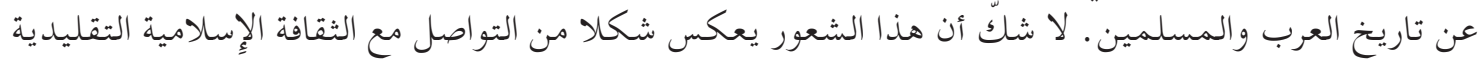

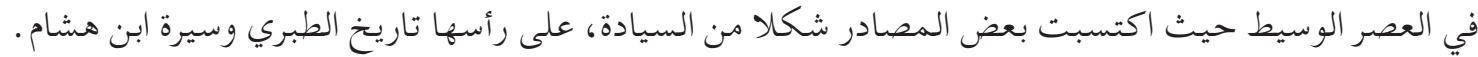

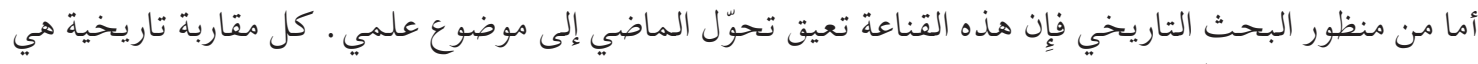

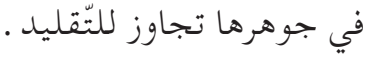




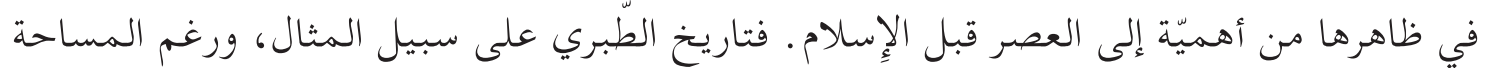

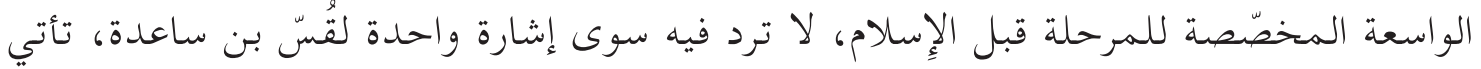

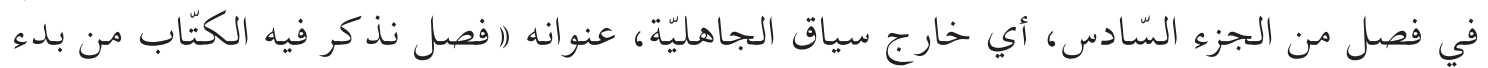

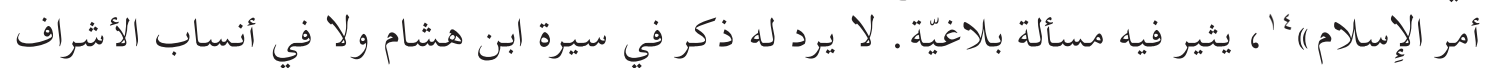

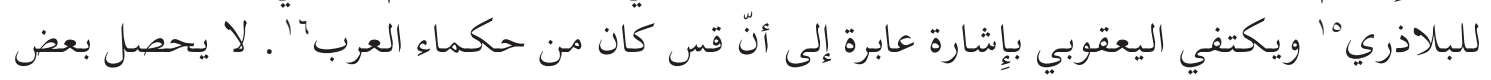

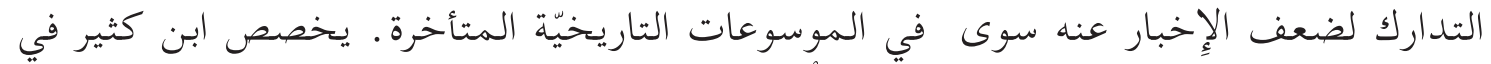

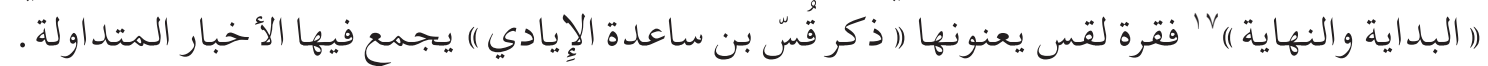

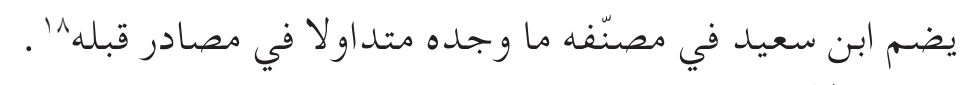

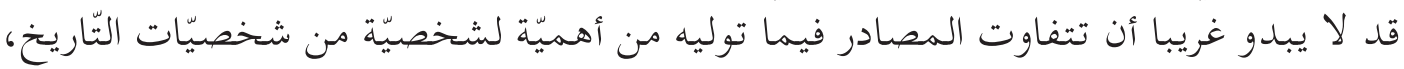

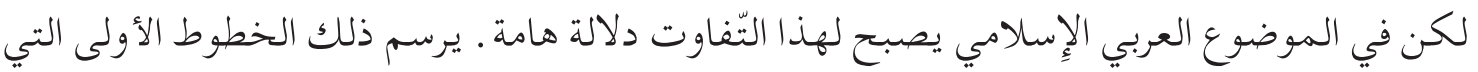

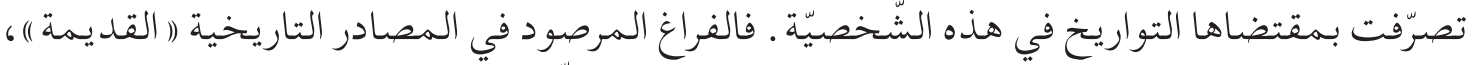

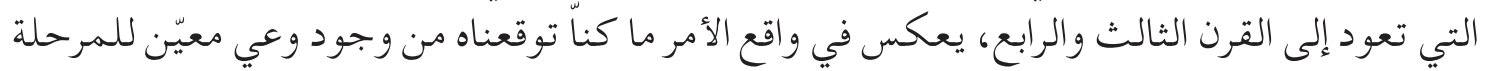

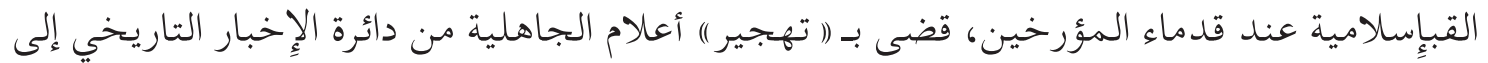

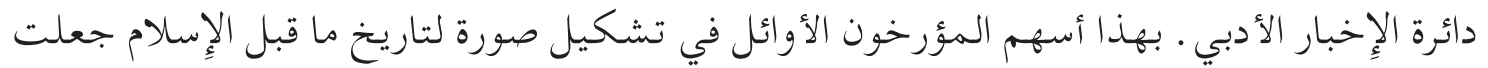

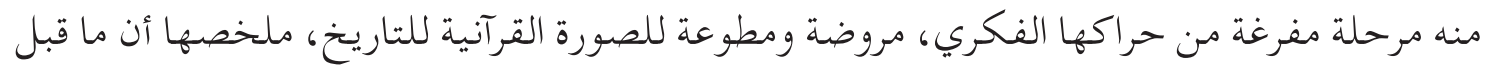

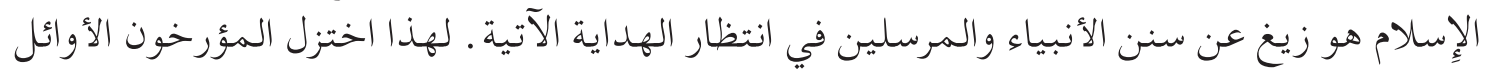

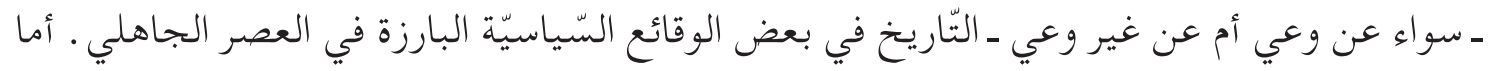

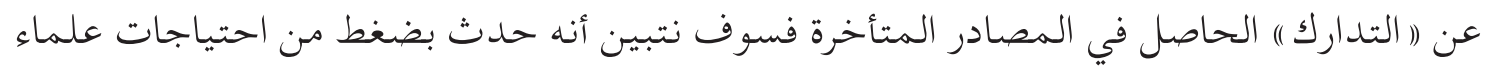

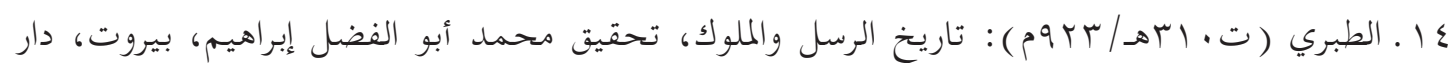

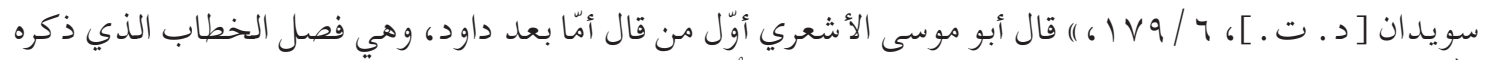

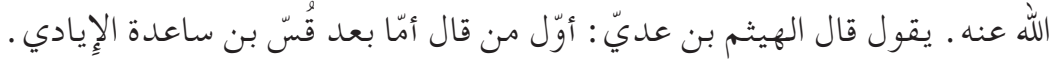

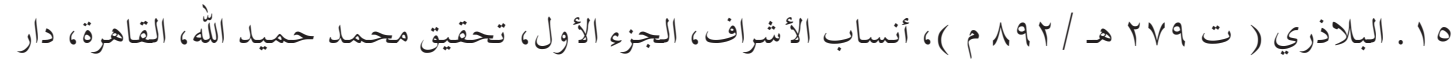

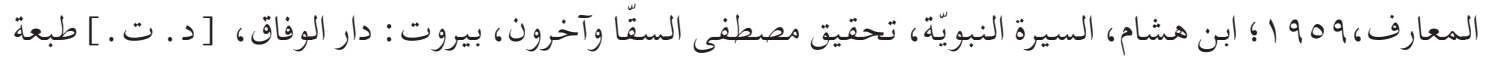

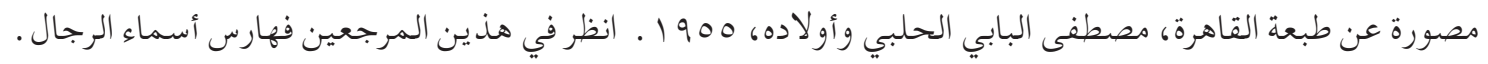

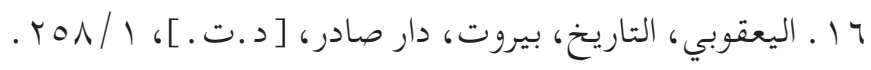

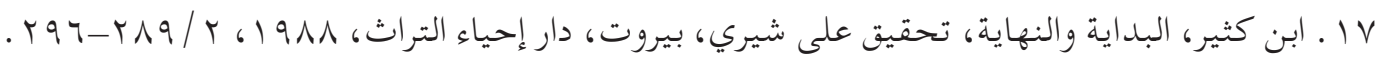

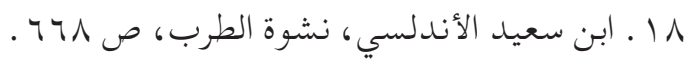


الحدديث . يببدو ابن كثيرو' في فقرته المخصصة لذ كر قس عديم الاكتراث بأخبار قس، كثير الاهتمام

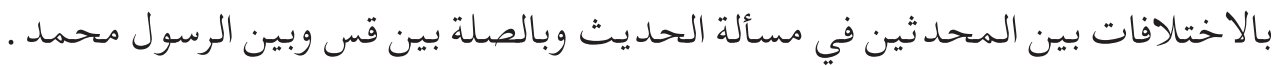

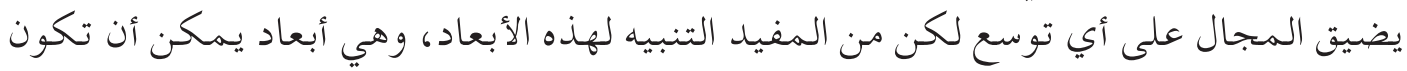

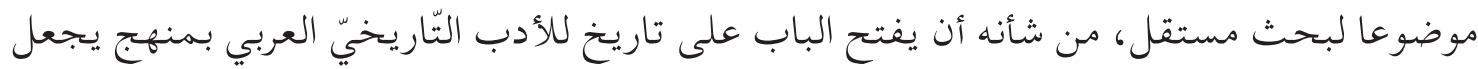

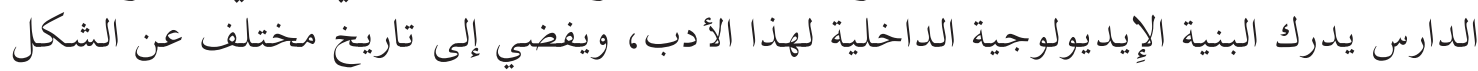
المدرسي المعهود . المرن.

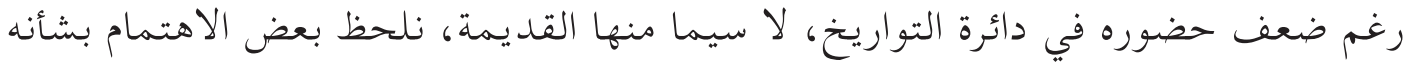

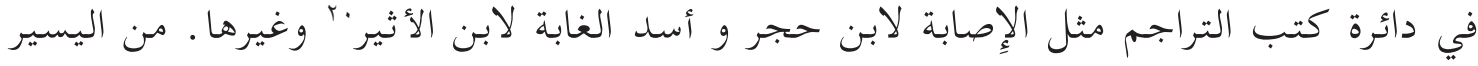

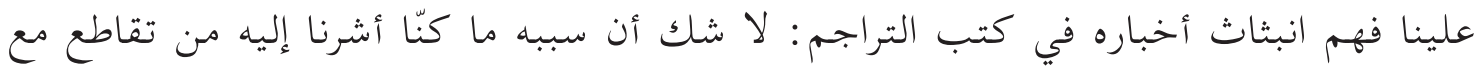

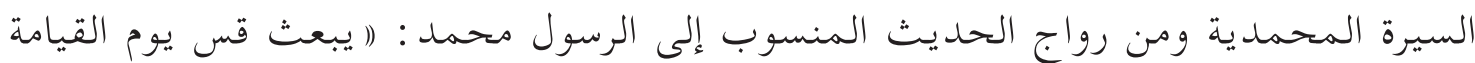

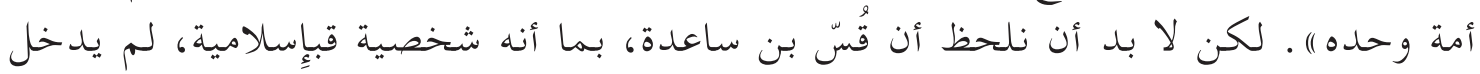

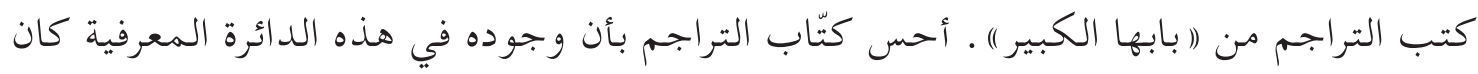

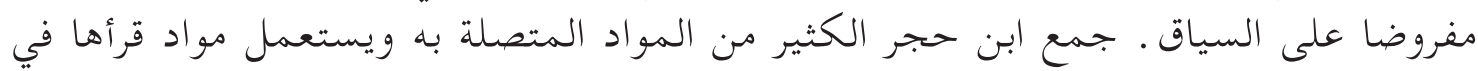

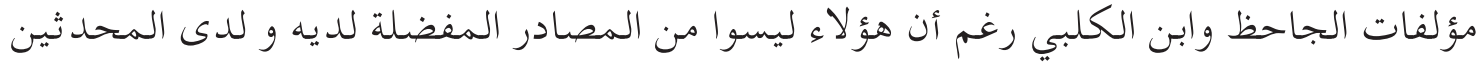

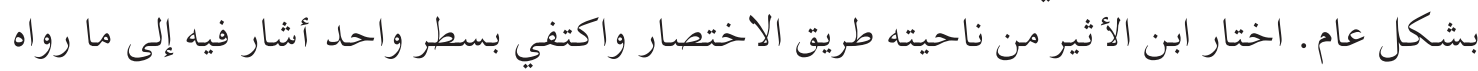

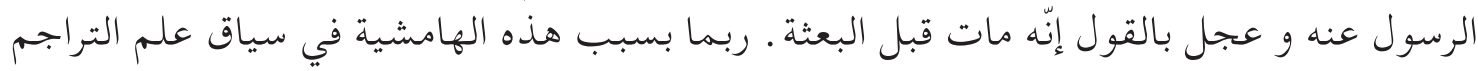

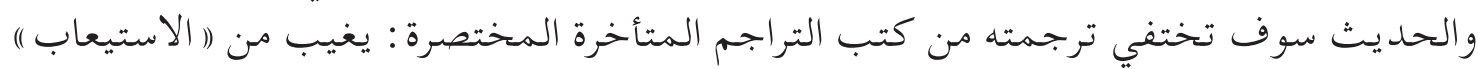

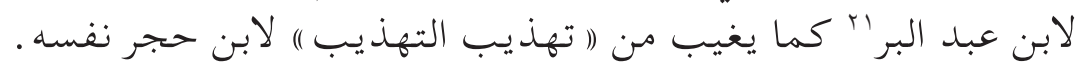

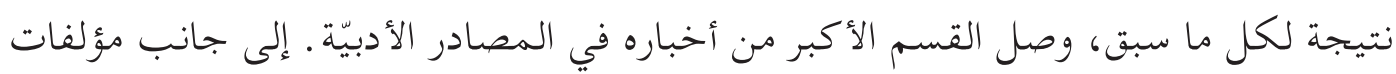

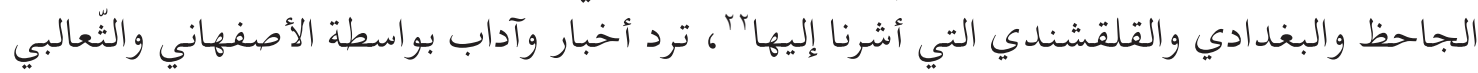

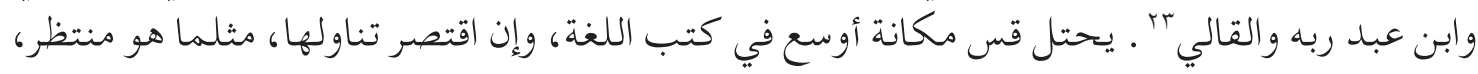

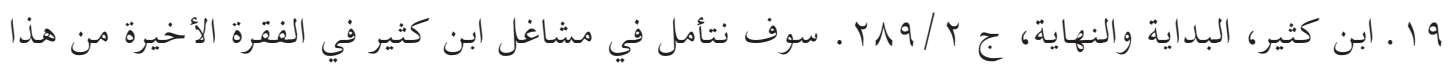
المقال.

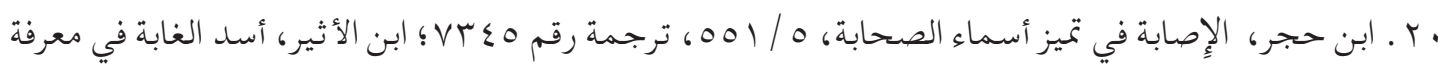

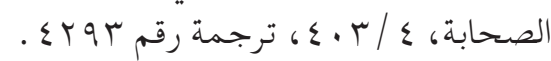

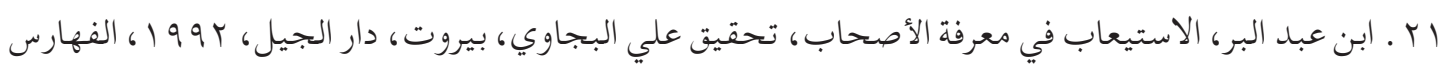

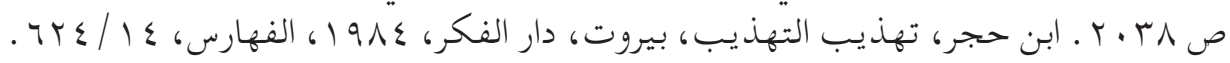

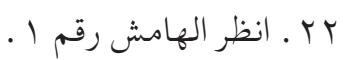

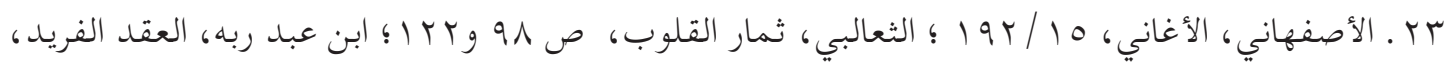

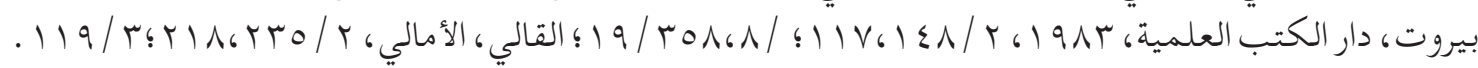


على أثره البلاغي واللّغويء . نلاحظ أيضا بعض الاهتمام بشأنه في المصادر ذات الطبيعة الإِخبارية

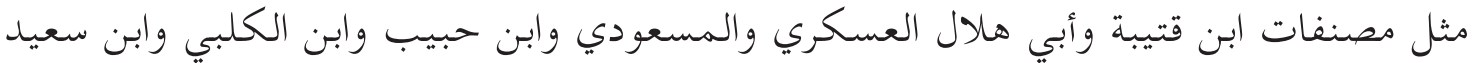

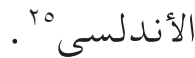

\section{بأي منهج}

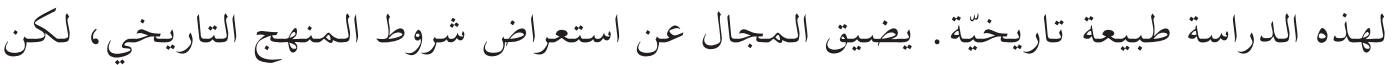

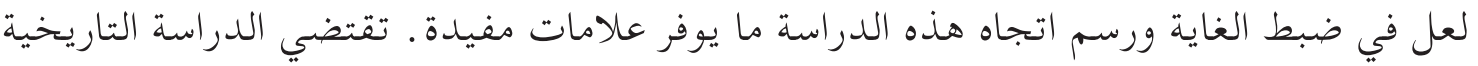

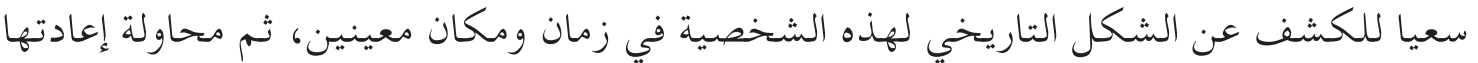

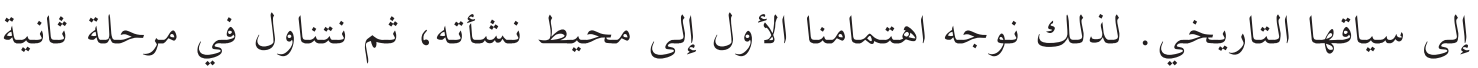

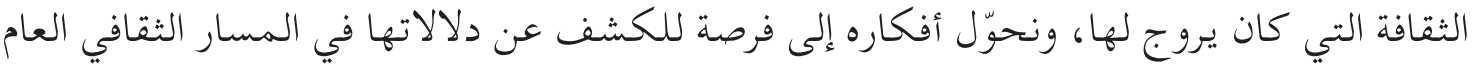

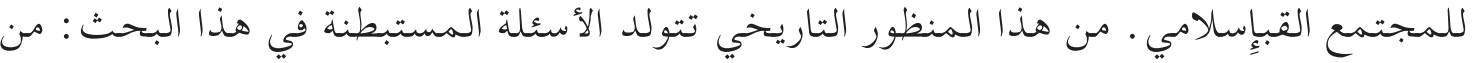

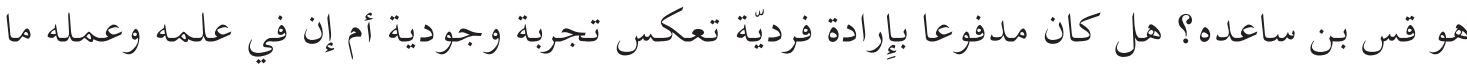

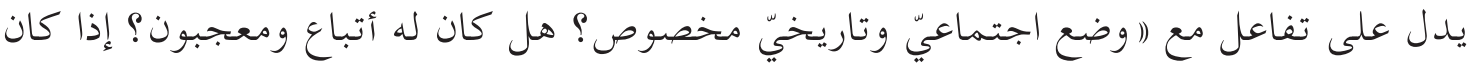

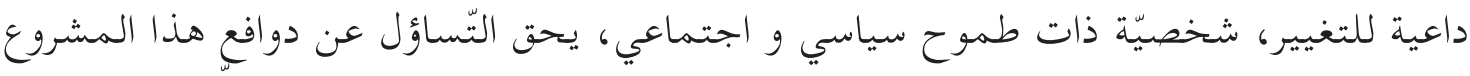

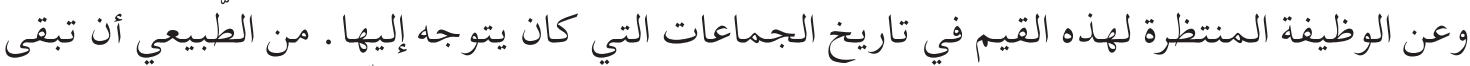

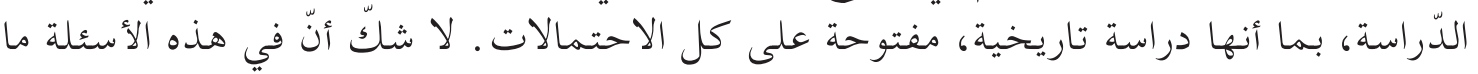

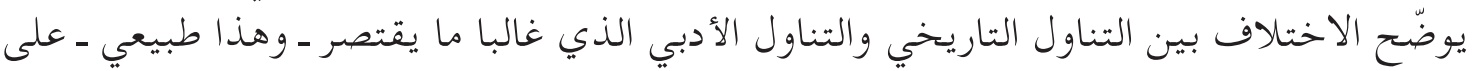

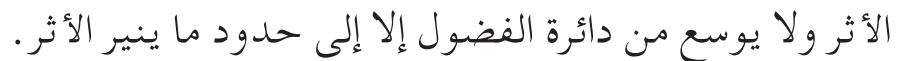

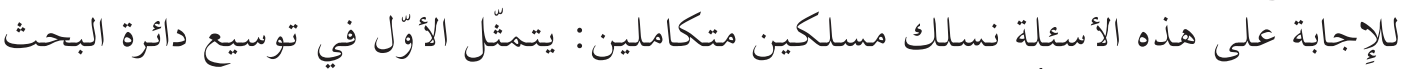

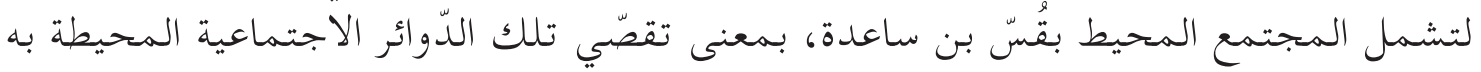

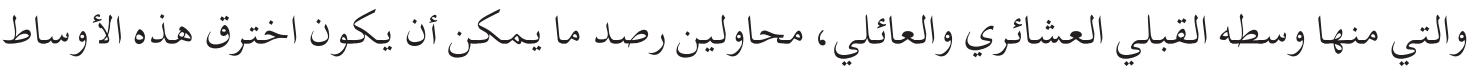

\& \&

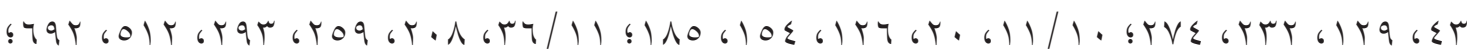

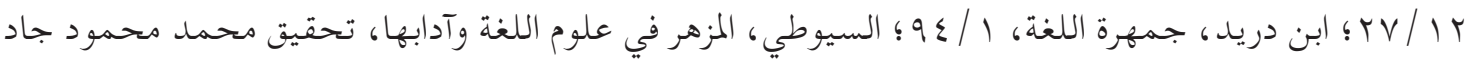

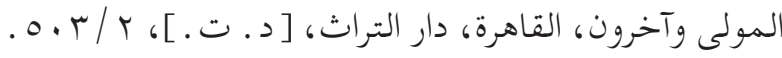

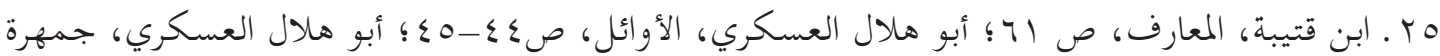

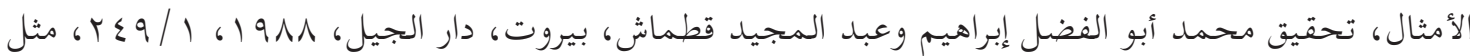

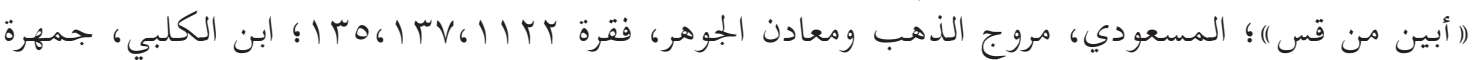

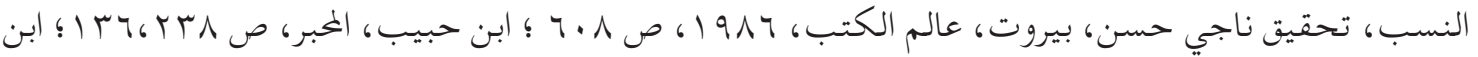

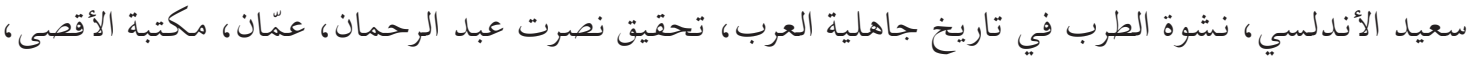
.TVY-TT1 ص (19人Y 


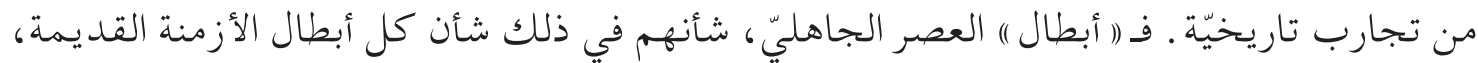

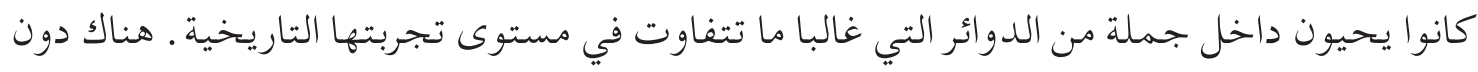

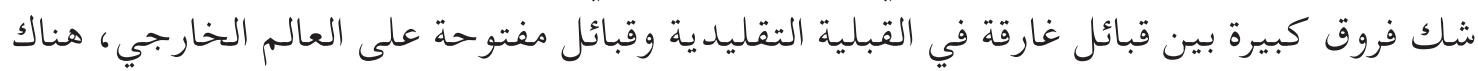

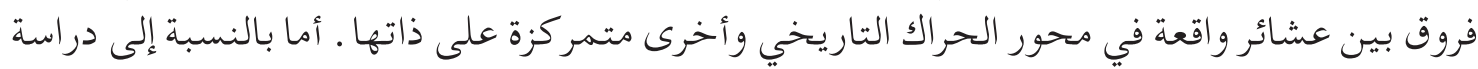

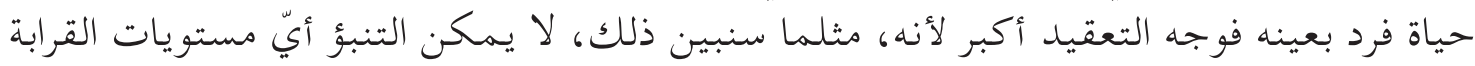

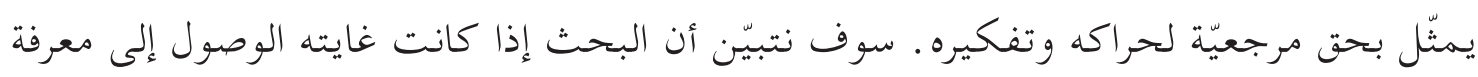

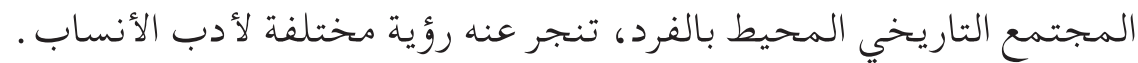

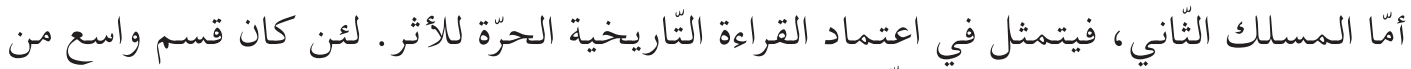

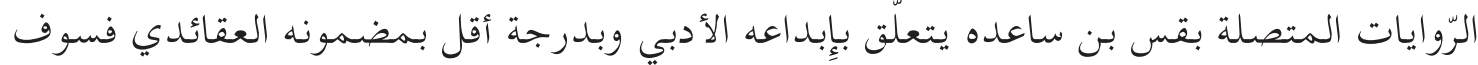

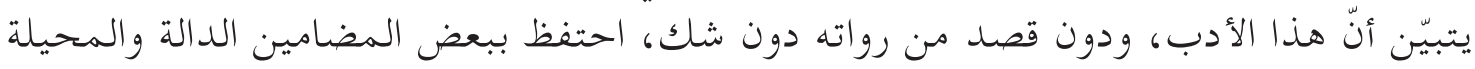

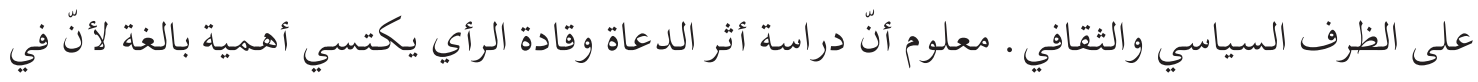

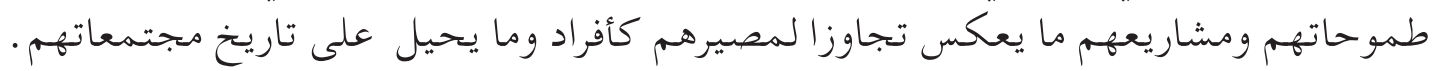

Y - التّحقيق بالنّسب : إلى أيّ وسط اجتماعي ينتمي قٌُّ ؟

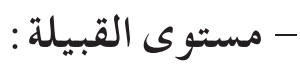

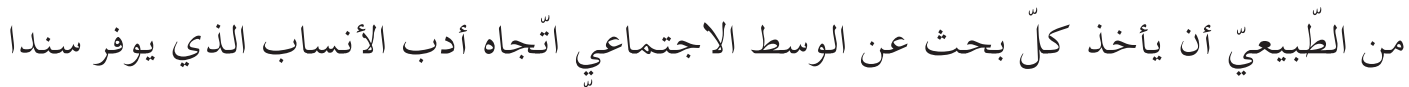

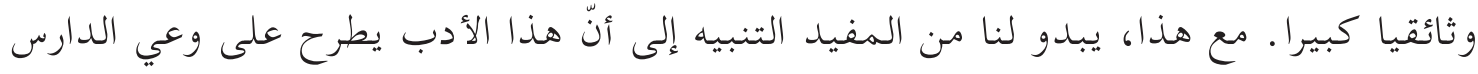

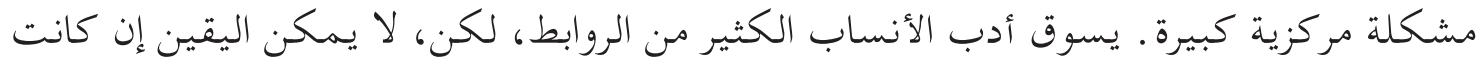

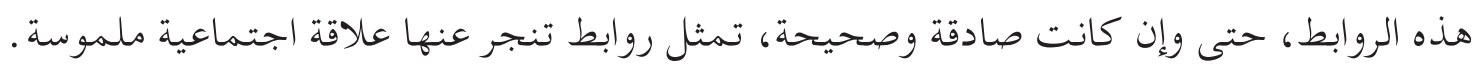

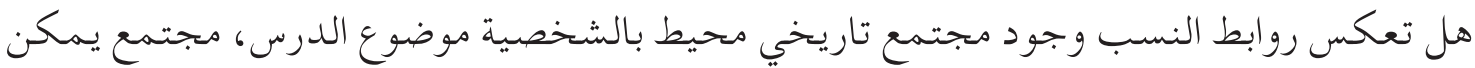

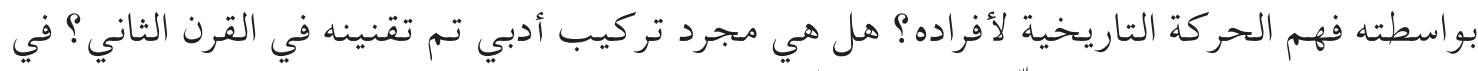

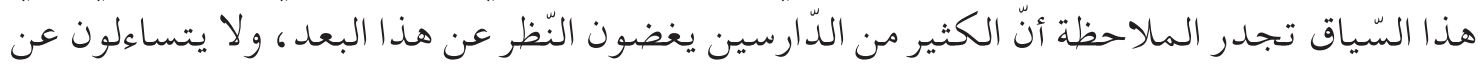

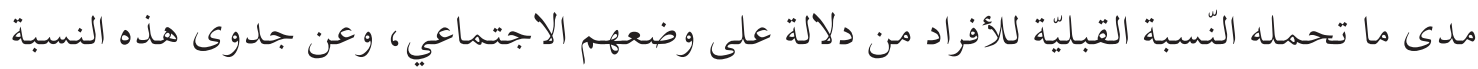

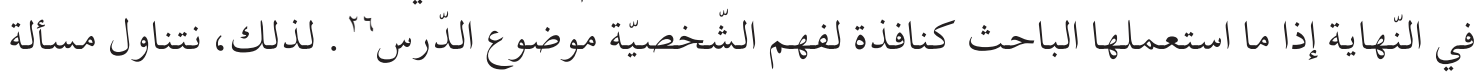

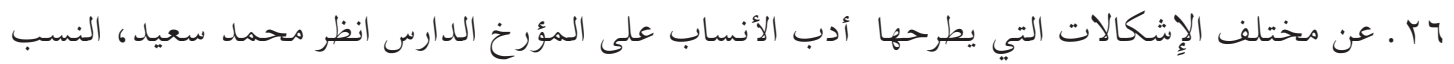

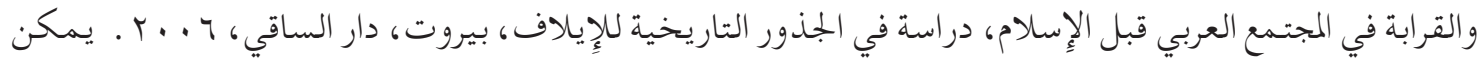

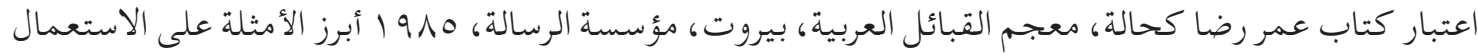

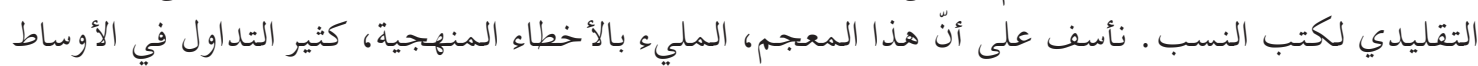

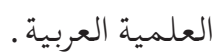




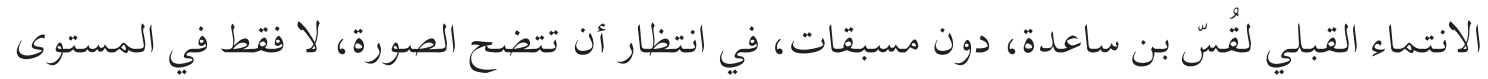

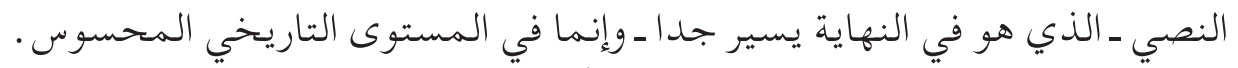

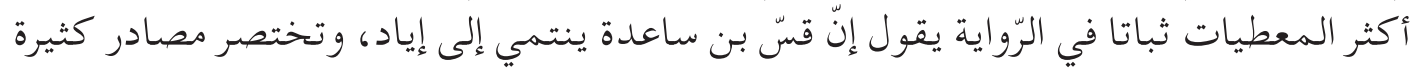

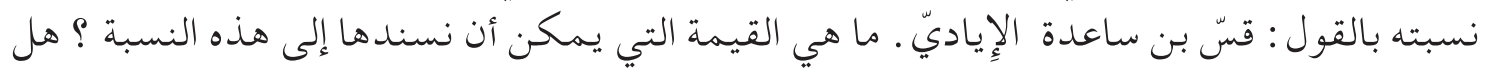

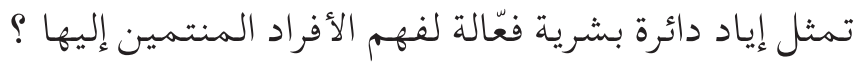

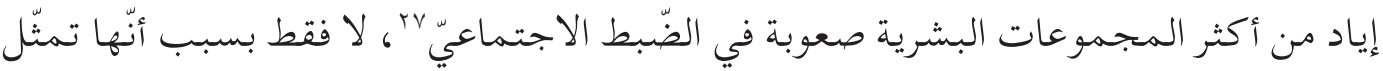

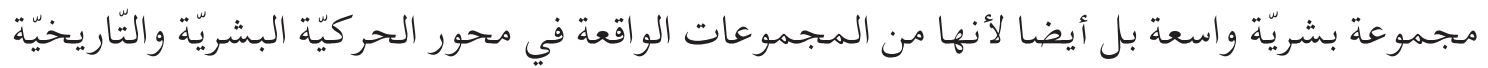

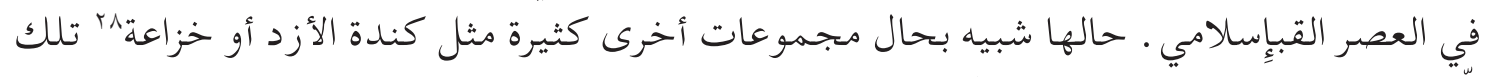

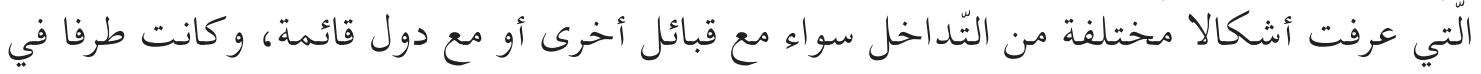

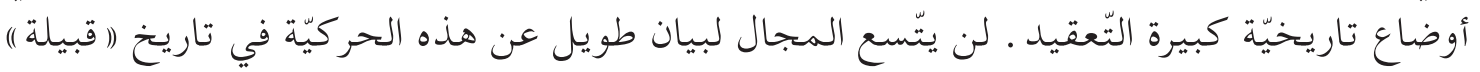

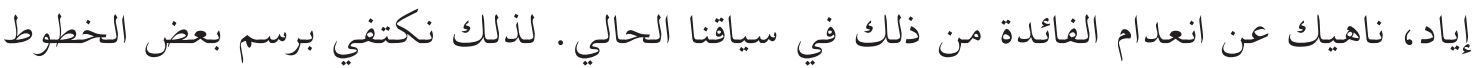

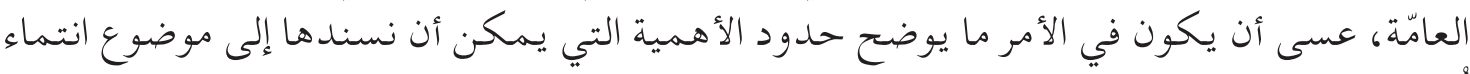
قُسّ إلى إياد.

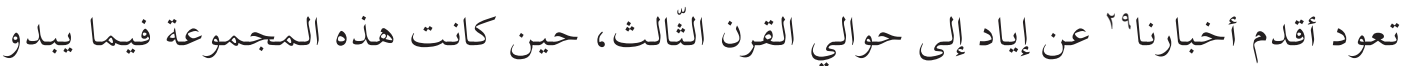

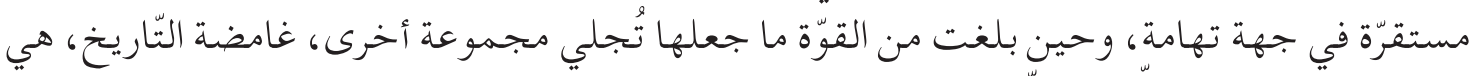

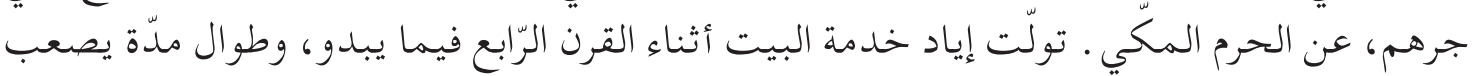

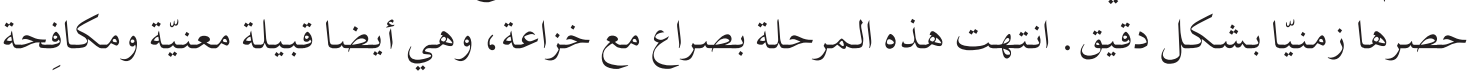

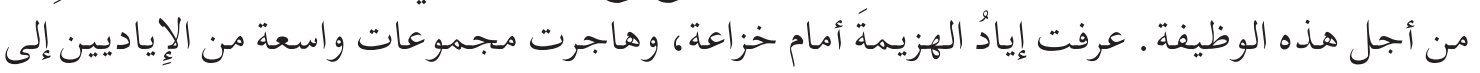

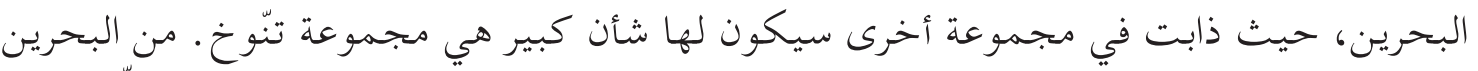

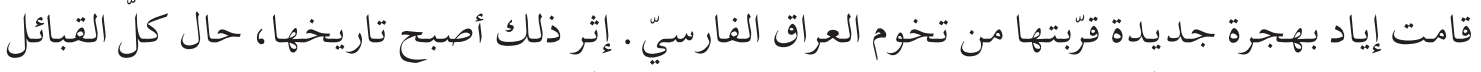

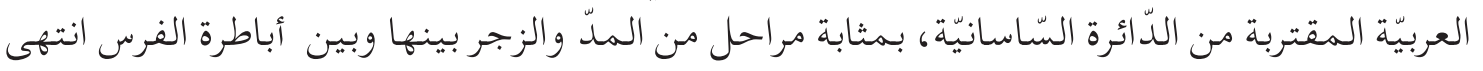

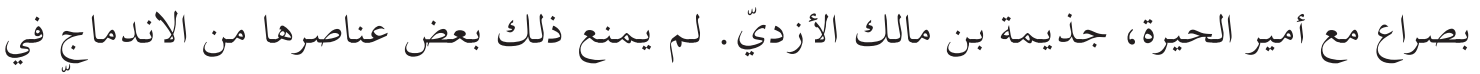

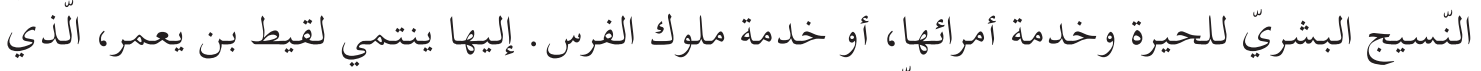

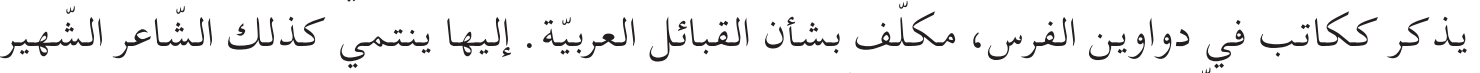

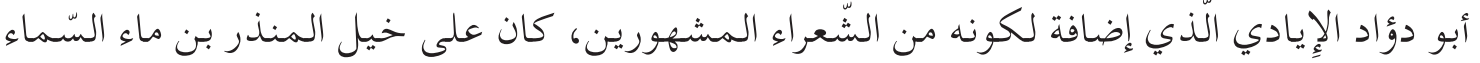

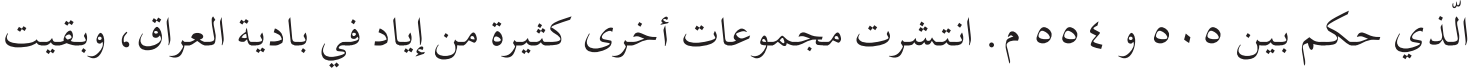




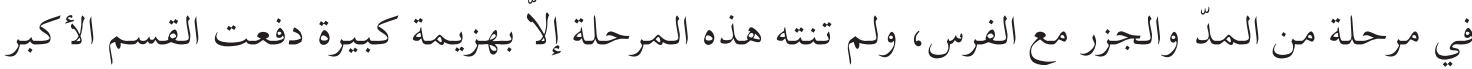

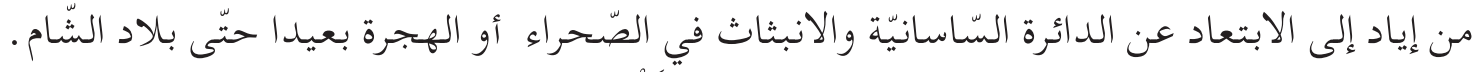

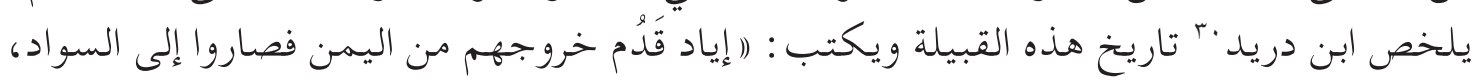

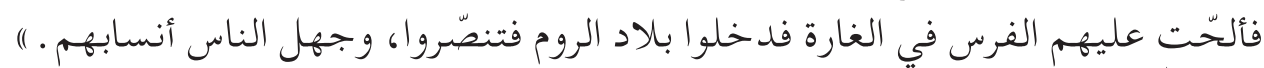

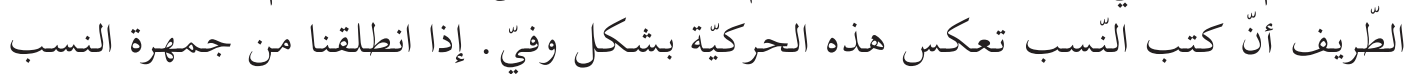

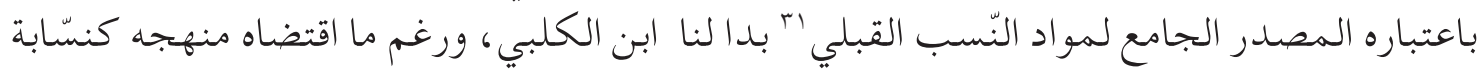

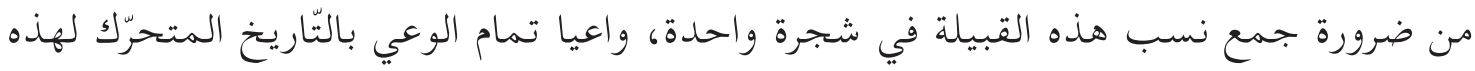

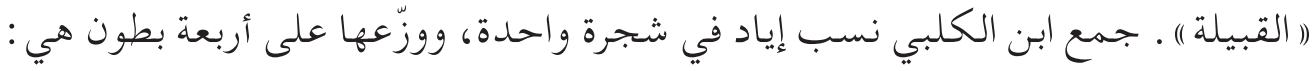

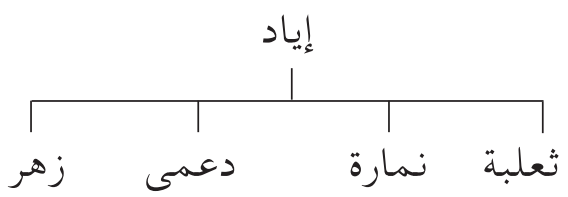

رغم هذا التّقنين أشار ابن الكالبي في طيّات نصّه، ولو بشكل مقتضبَ، إلى مختلف التّطورات

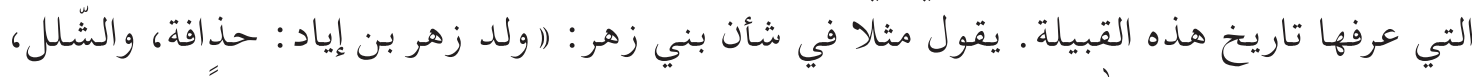

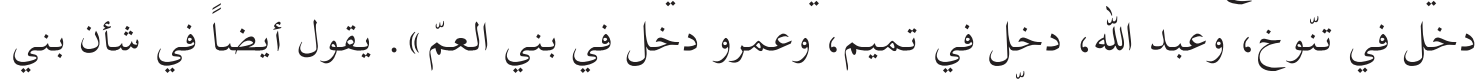

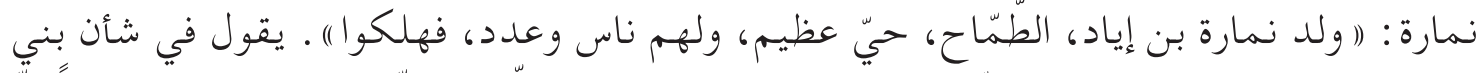

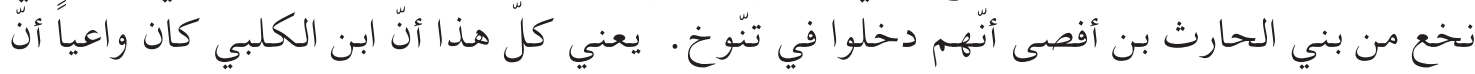

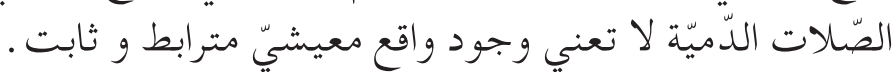

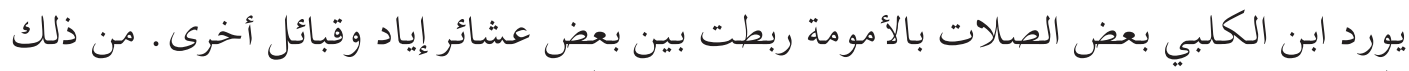

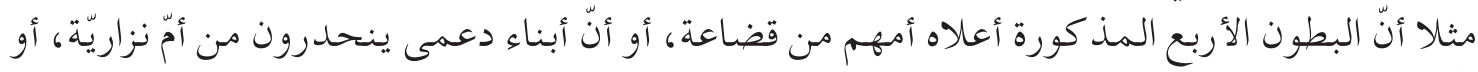

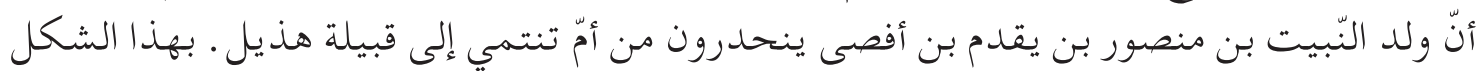

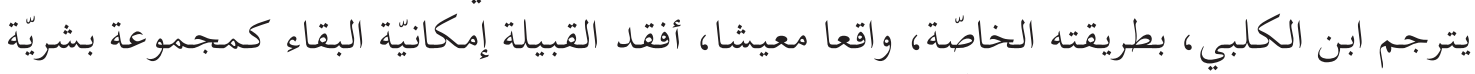

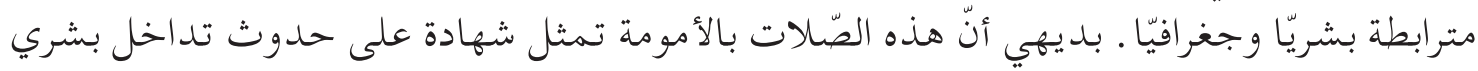

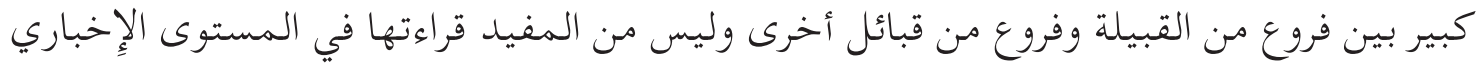
الأولي .

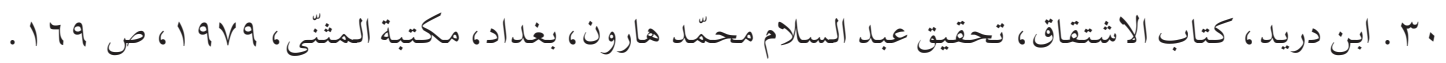

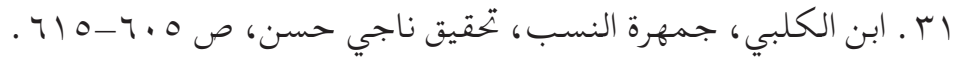




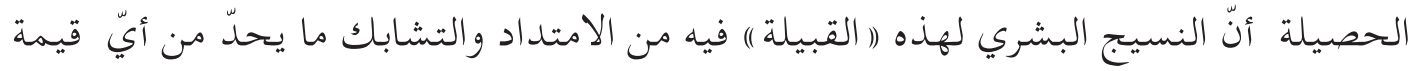

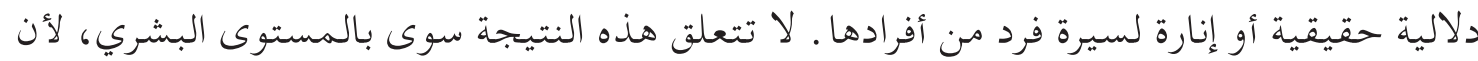

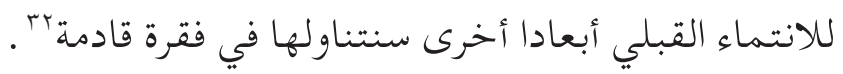

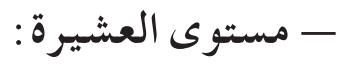

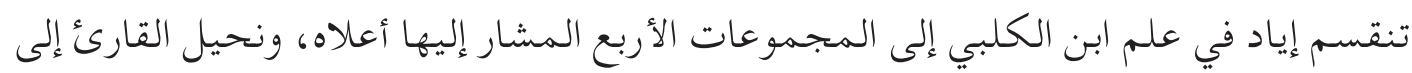

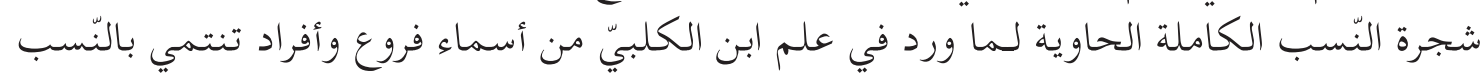

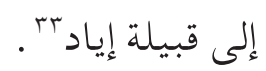

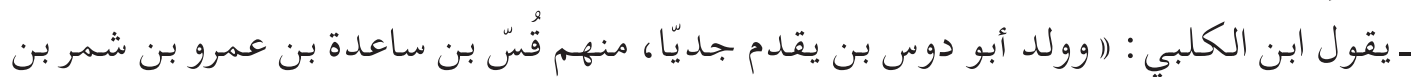

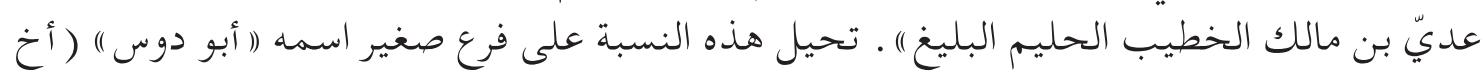
لعوذ مناة، يأتي في (ا الجيل ) الرّابع ) .

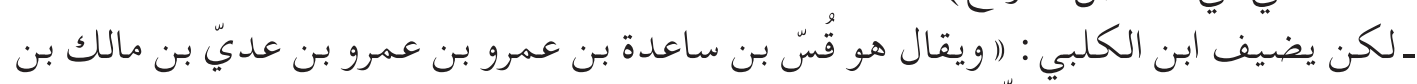

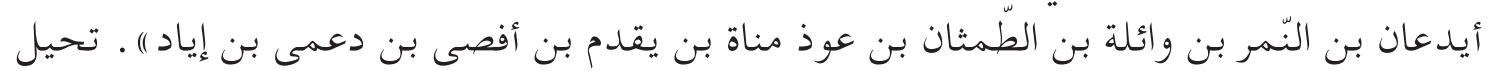

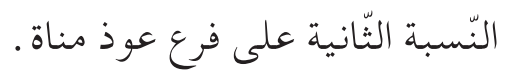
من الواضح أن ابن الكلبيّ أبقى على النّلى احتمالين : احتمال أنّ قس ينحدر من أبي دوس واحتمال

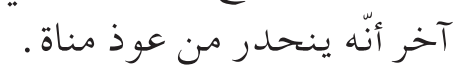

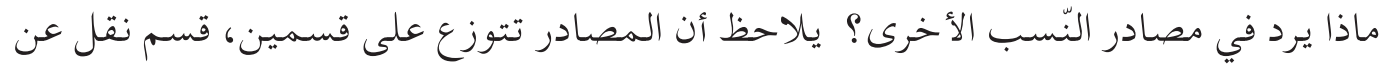

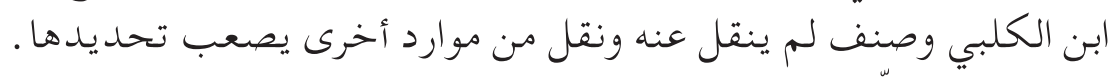

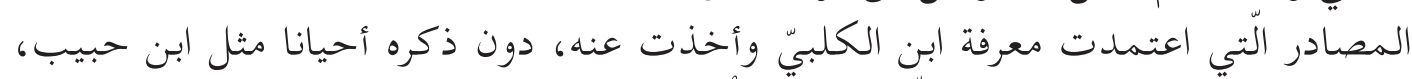

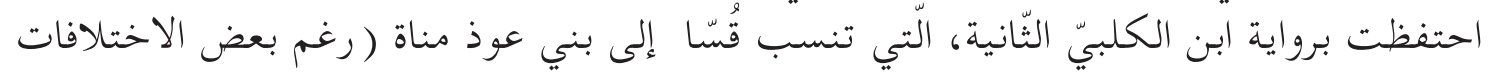

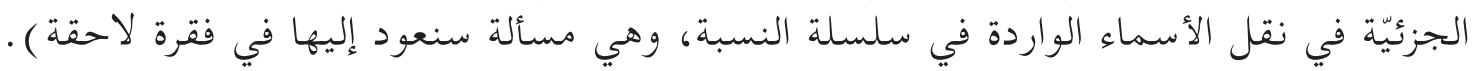

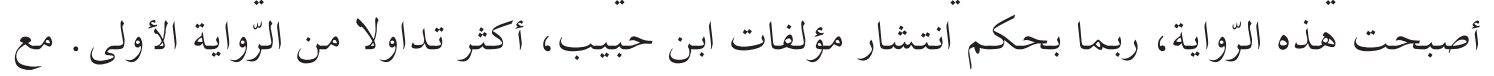

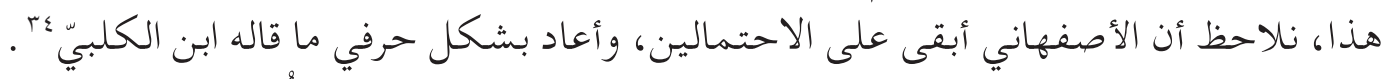

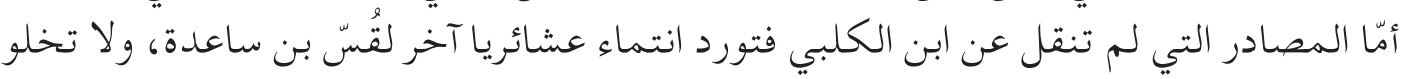

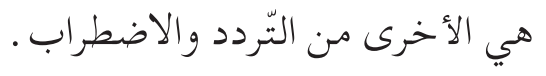

بr. انظر فقرة : (اعودة للوسط الإِيادي)".

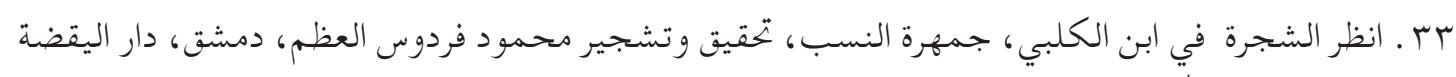

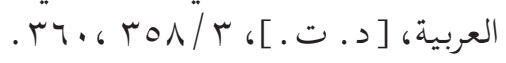

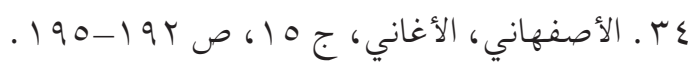


يرد في ترجمته في الإصابةهُ : قُّّ بن ساعدة بن حذافة بن زفر بن إياد بن نزار الإِيادي البليغ

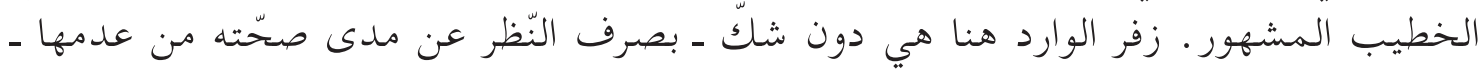

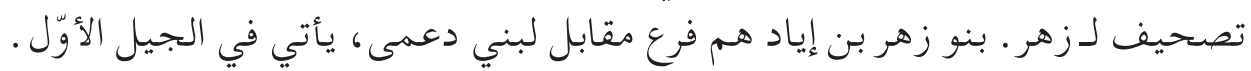

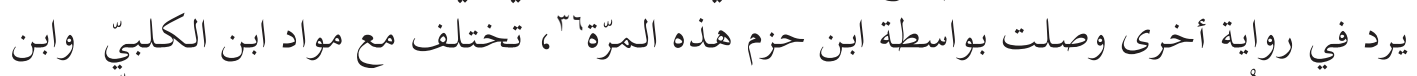

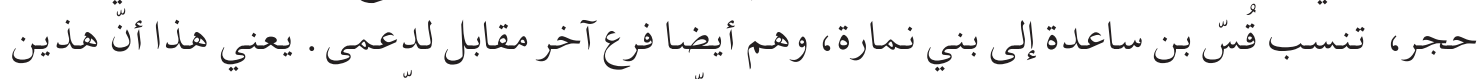

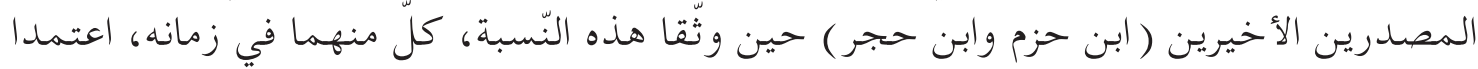

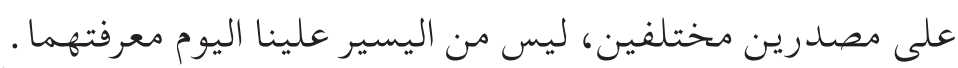

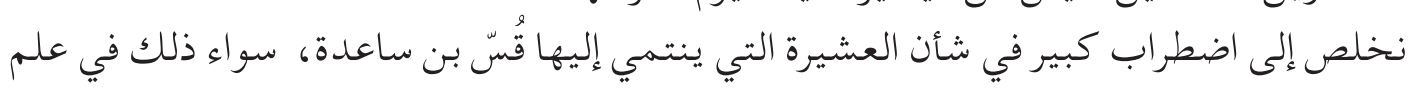

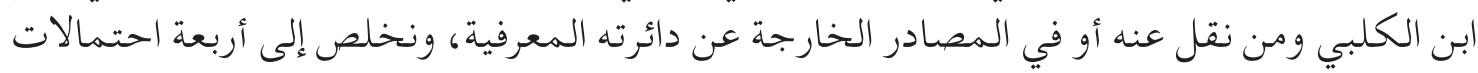

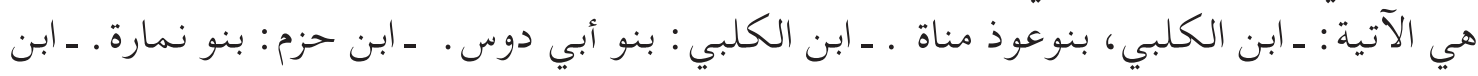

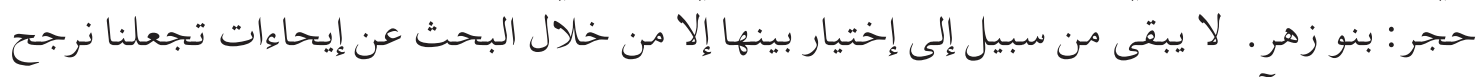
أحدها على الآخر.

$$
\text { - الاحتمال الأوّل : بنو عوذ مناة : - ل }
$$

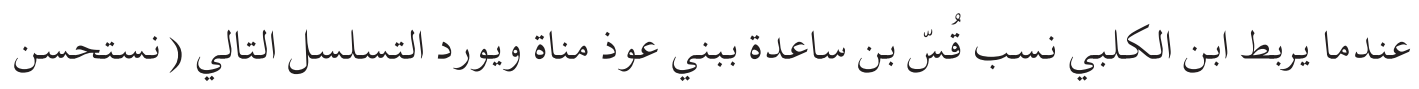

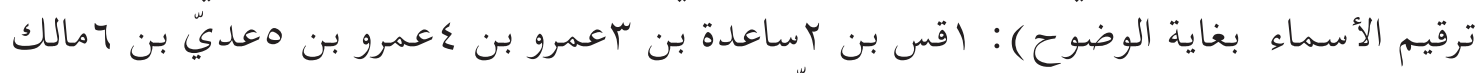

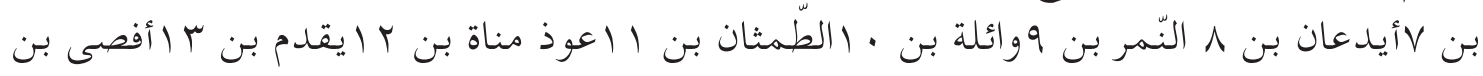
؛ إدعمى بن 0

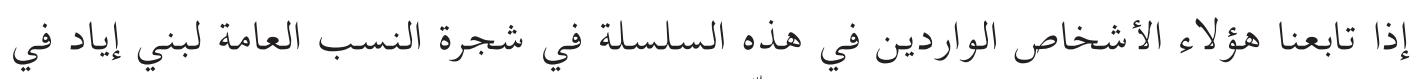

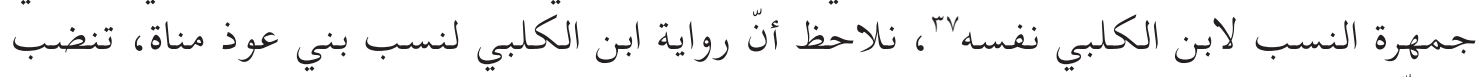

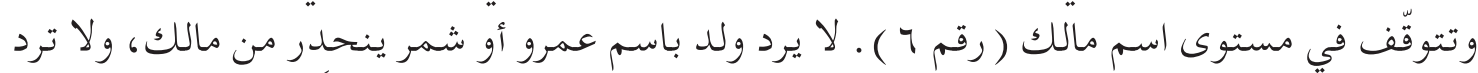

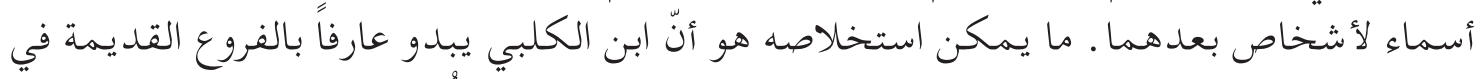

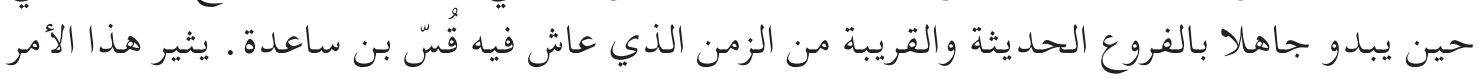

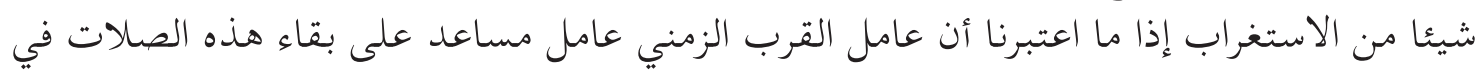

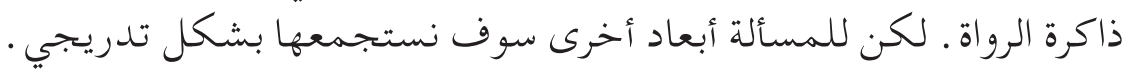

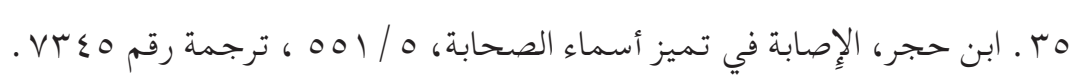

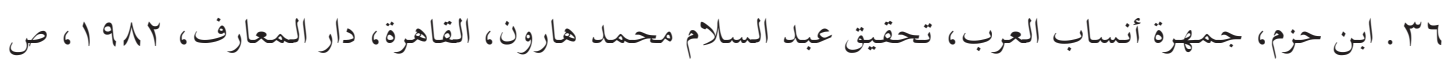
( )

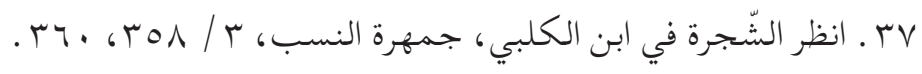


- الاحتمال الثّاني، بنو أبي دوس:

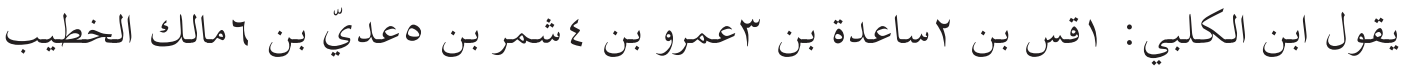

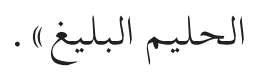

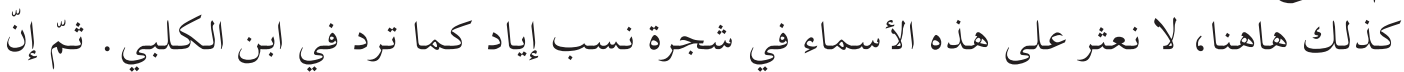

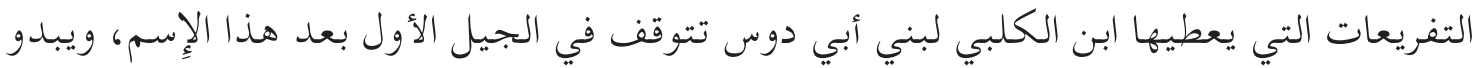

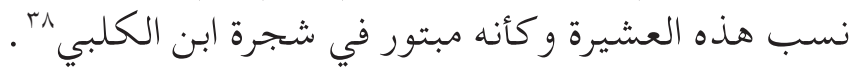

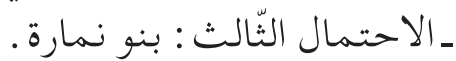

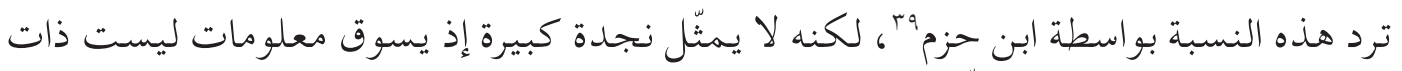

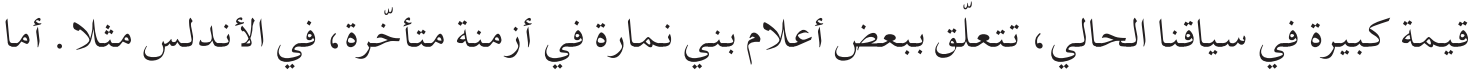

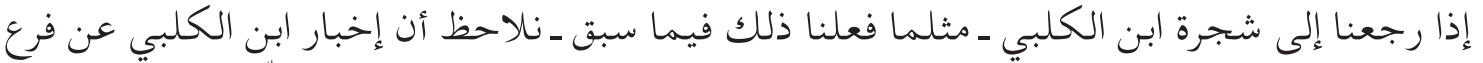

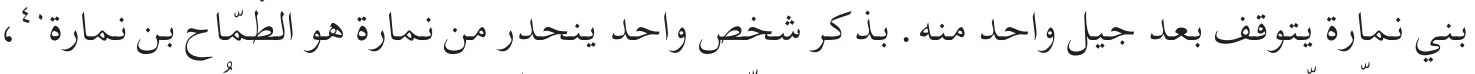

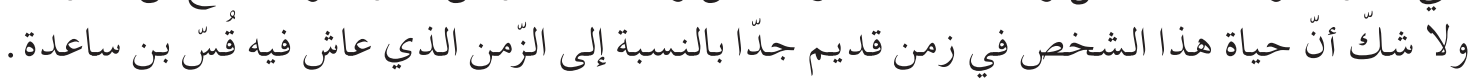

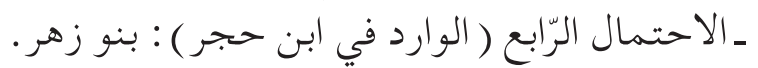

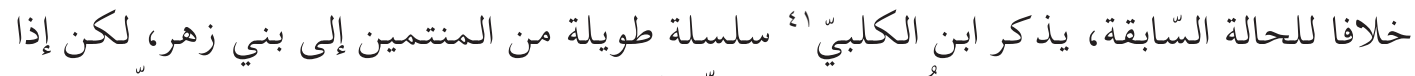

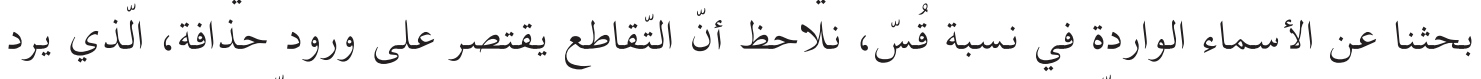

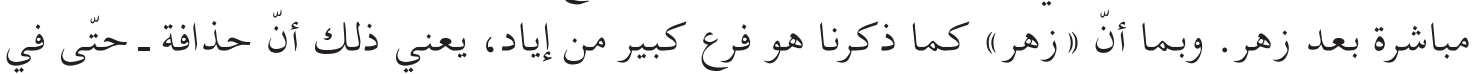

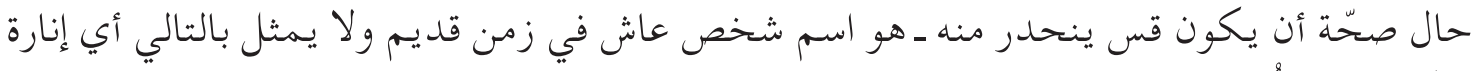

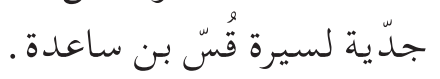

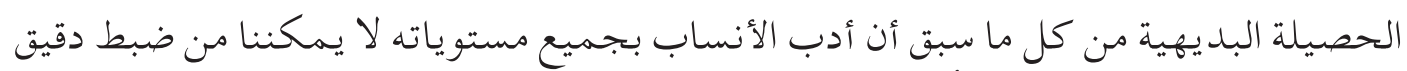

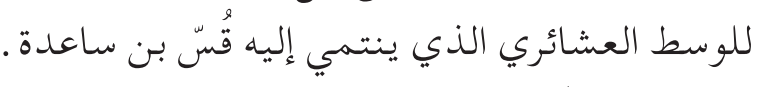

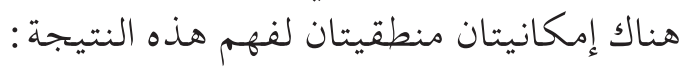

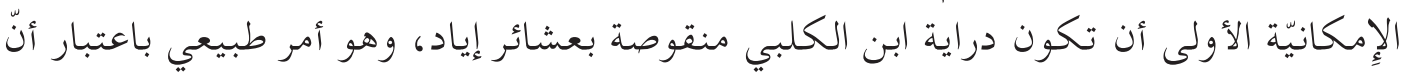

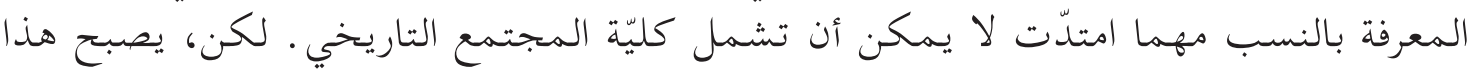

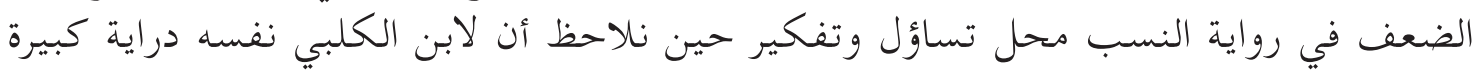

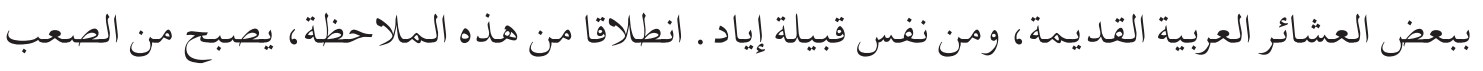

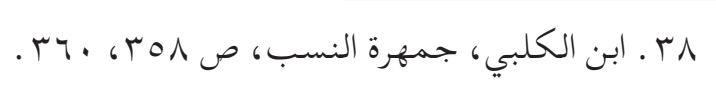

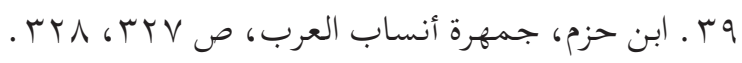

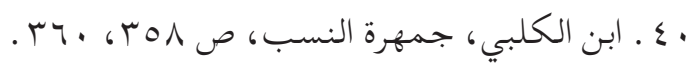

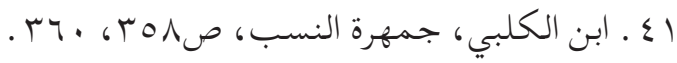




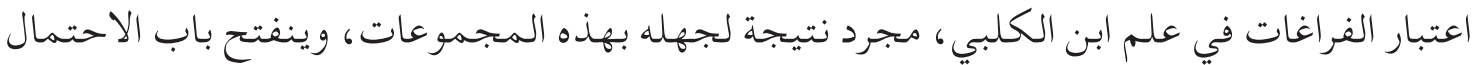

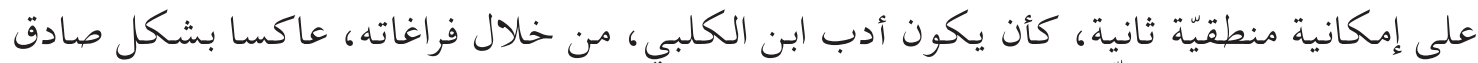

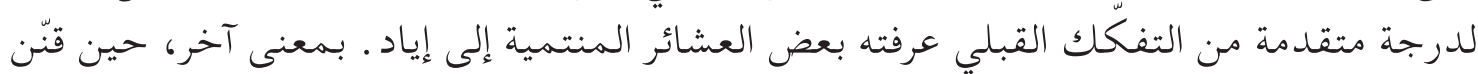

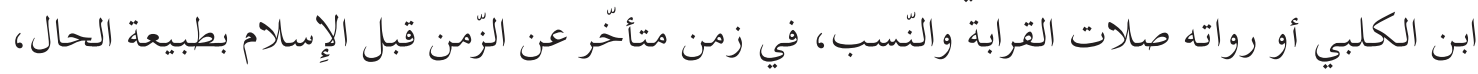

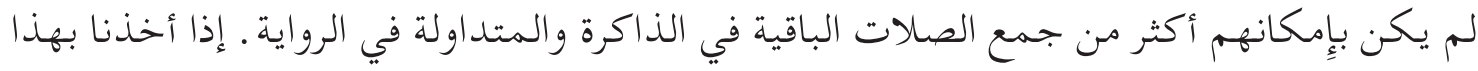

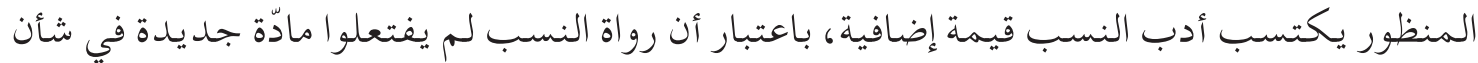

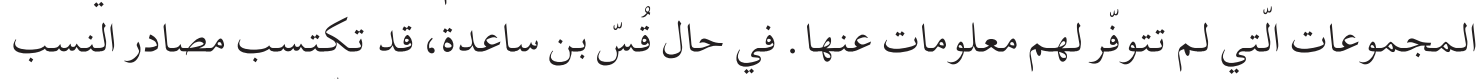

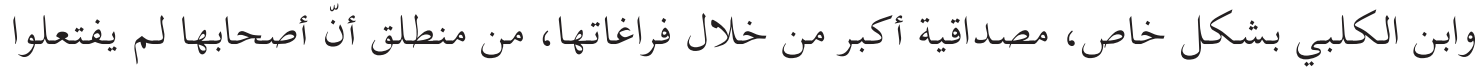

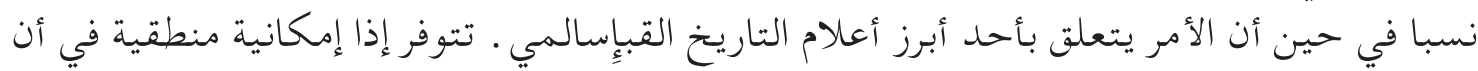

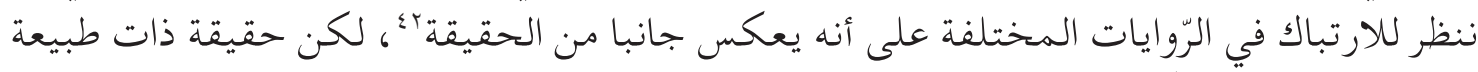

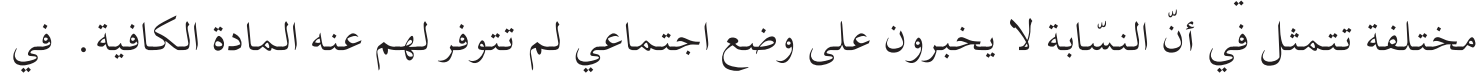

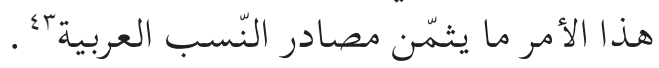

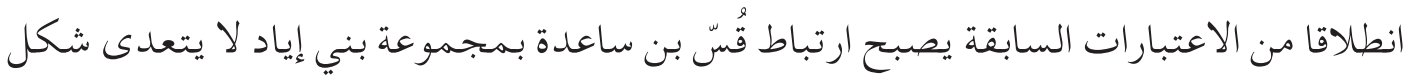

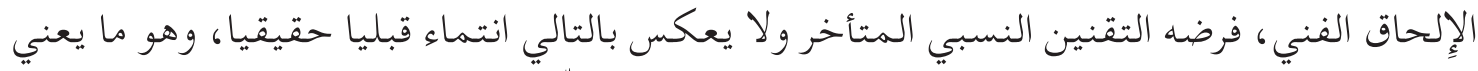

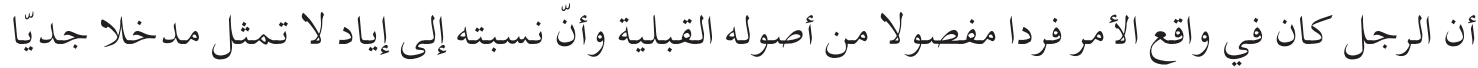

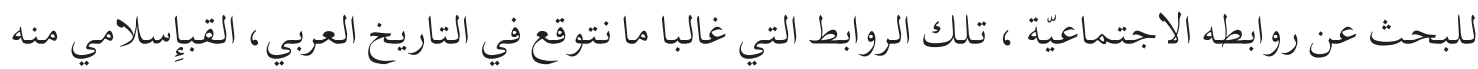

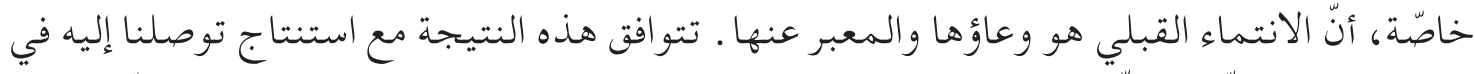

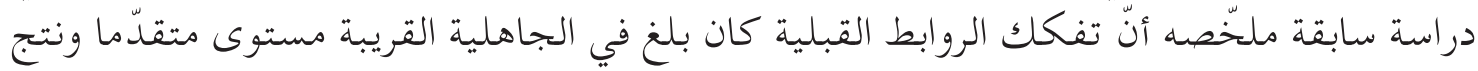

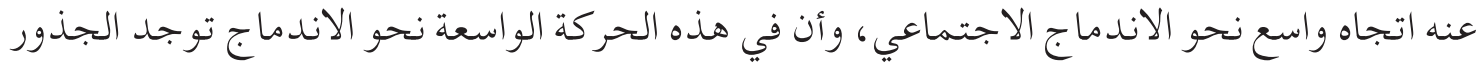

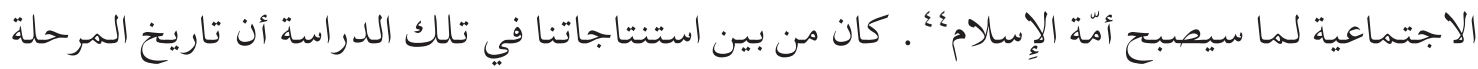

بـ ـ ـ نتيجة لذلك، فإِنّ المطلوب ليس فقط استثمار أدب النّسب وإنِّا أيضا قراءة الفراغات الّتي تصبح بدورها فراغات دالّة.

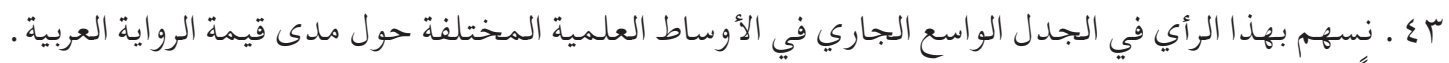

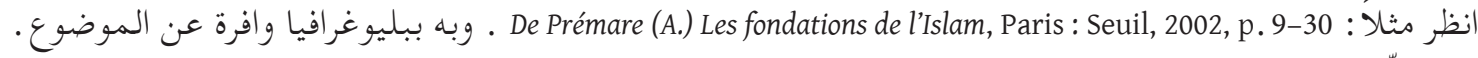

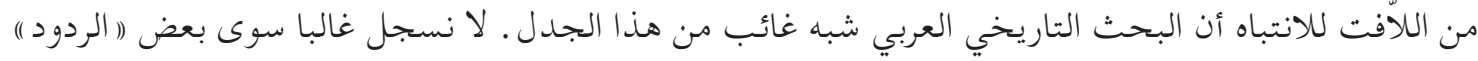

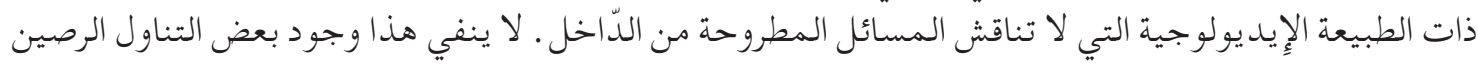

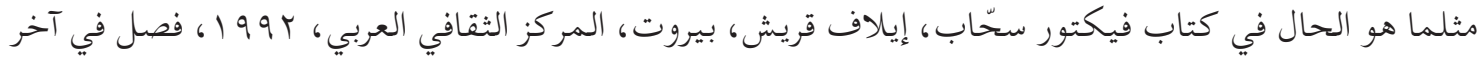

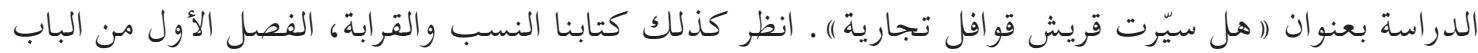


القريبة من الإِسلام لا يمكن وعيه انطلاقا فقط من أنه تاريخ قبائل، وأن النّسبة القبلية لا تمثّل، في

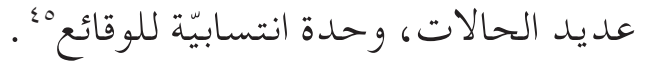

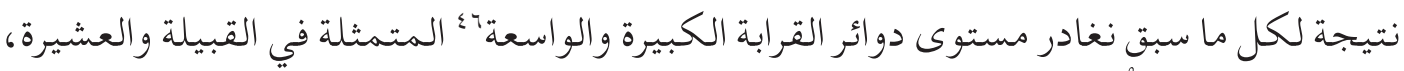

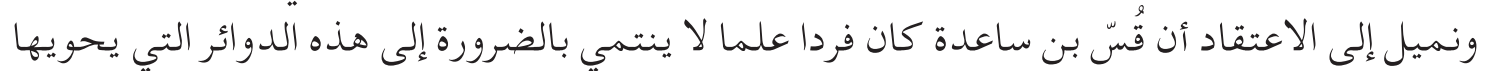

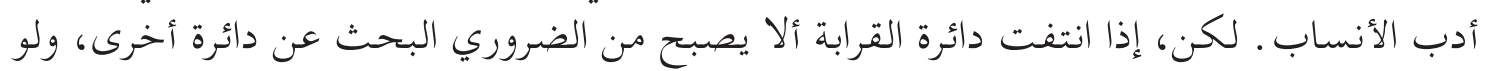

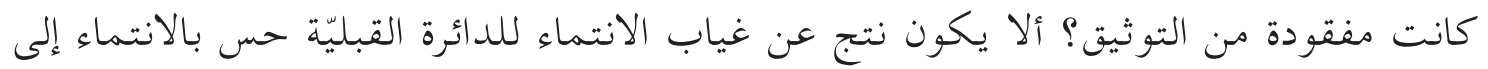

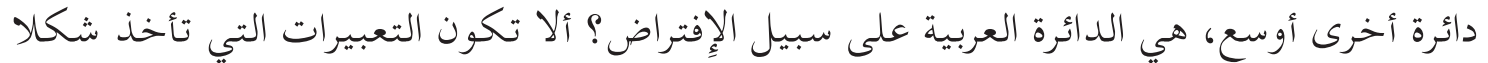

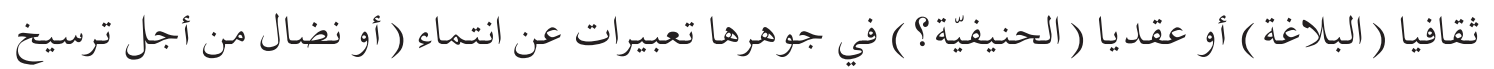

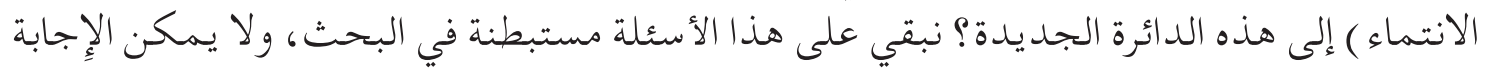

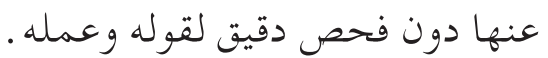

\section{ـ مستوى الفرد و الدائرة العائلية :}

الاسمه : الفردي، قُسّ ( بضمّم القاف ) . أول ما يلاحظ هو غياب هذا الاسم كاسم علم من رصيد

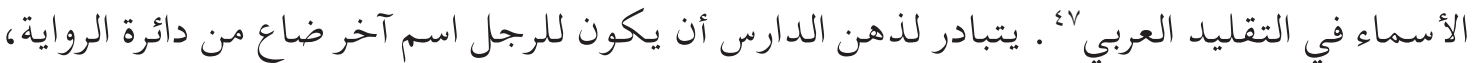

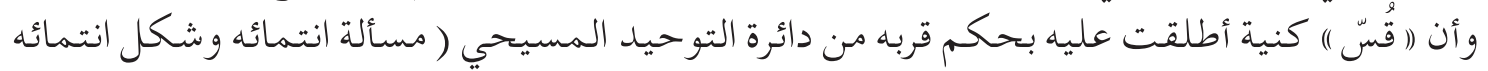

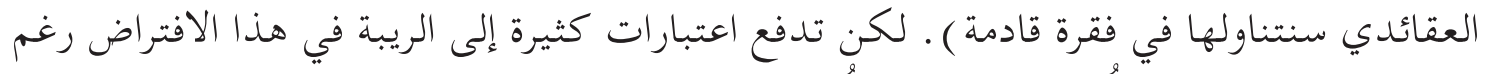

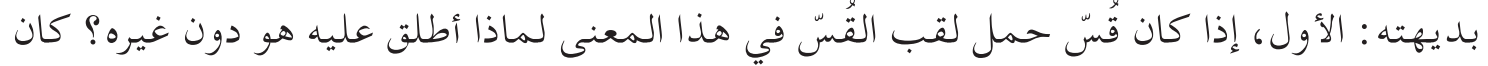

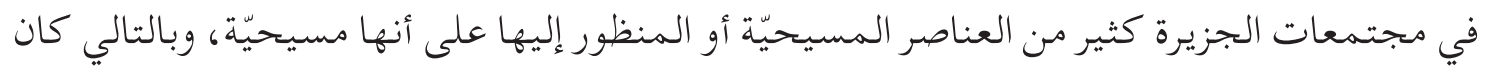

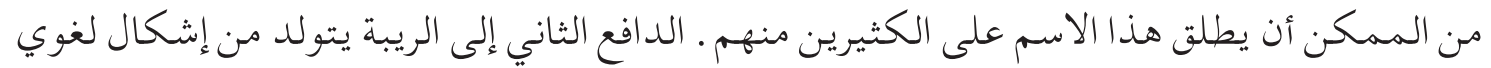

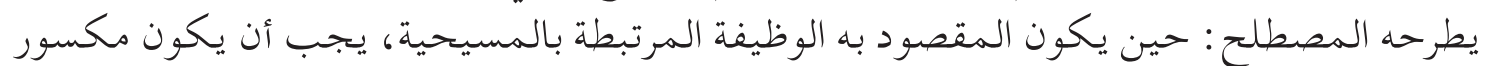

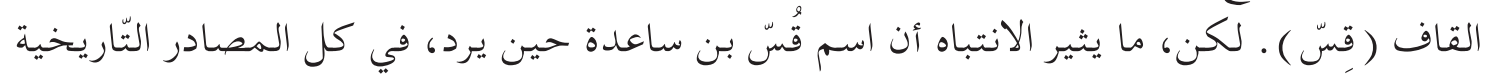

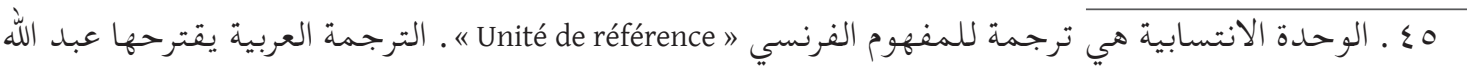

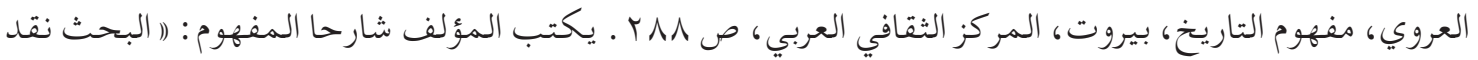

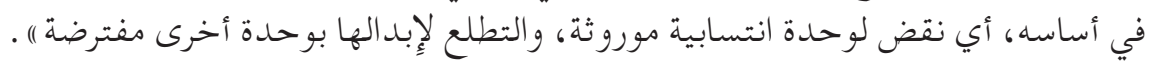

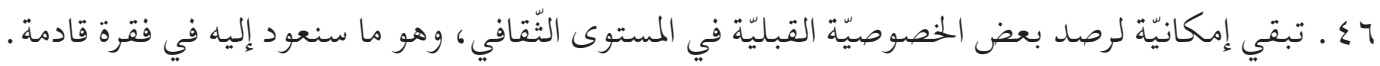

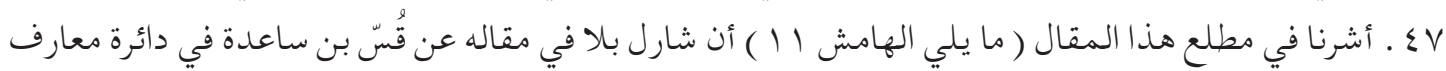

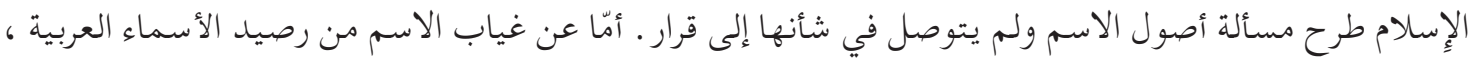

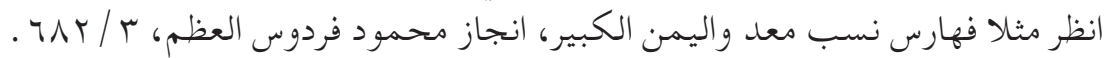


و الأدبية دون استثناء، يرد مشكو لا ومضموم القاف وليس مكسورها ولا مفتوحهاء؛ ، وبالتالي يصبح

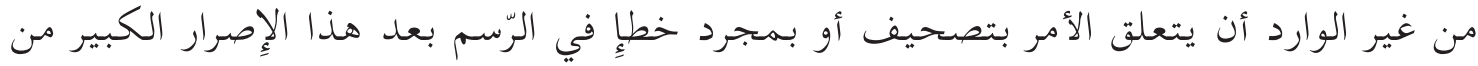

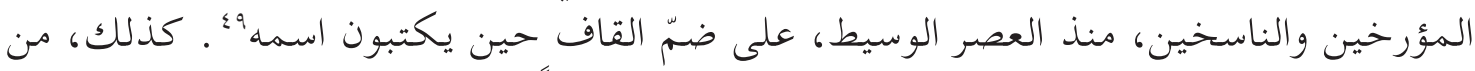

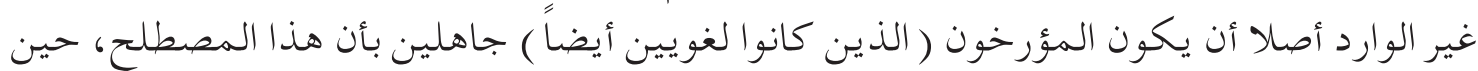

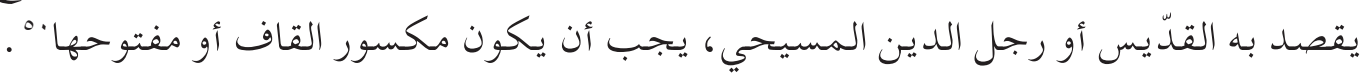

$$
\text { ما رأي اللّغويين؟ }
$$

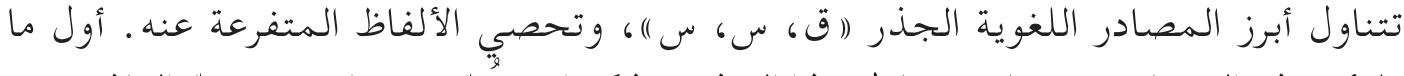

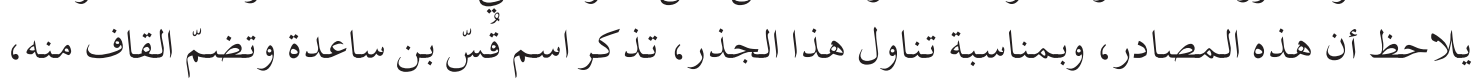

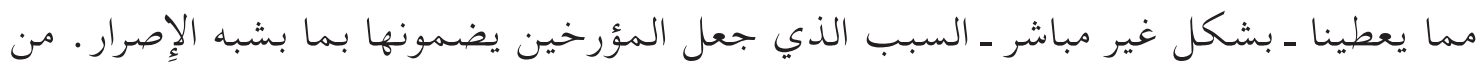

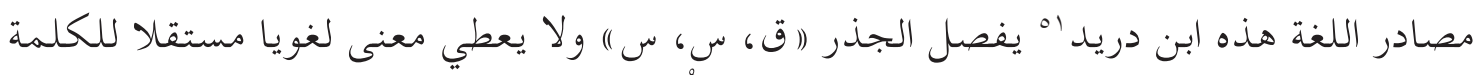

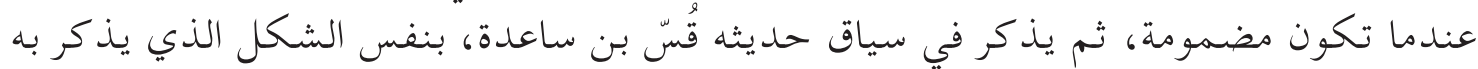

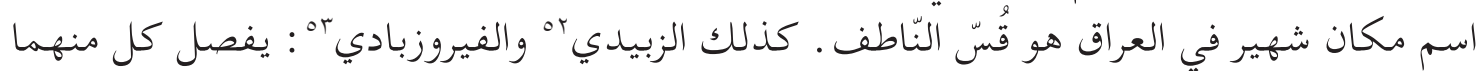

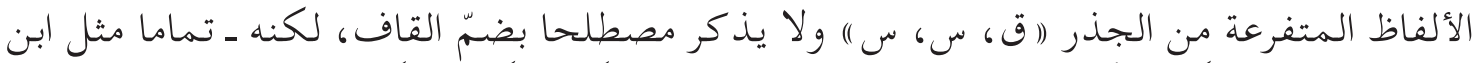

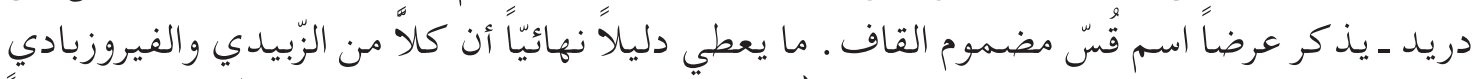

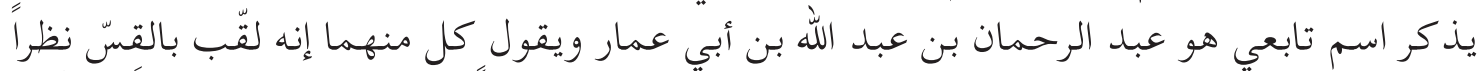

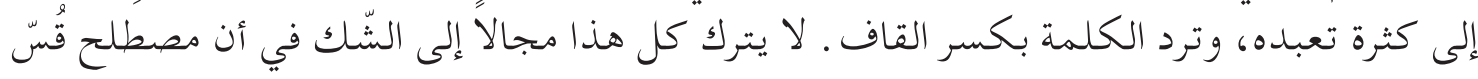

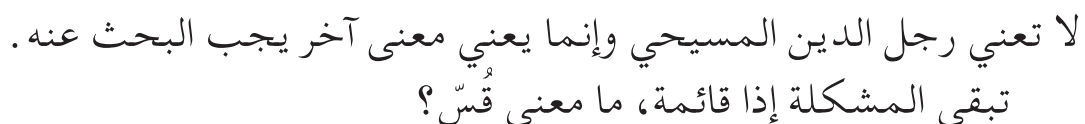

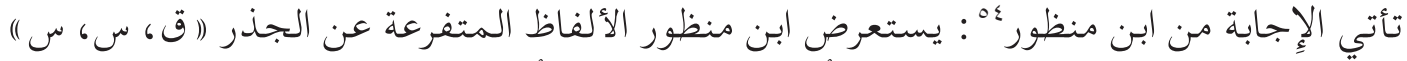

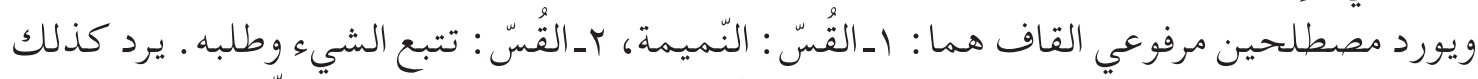

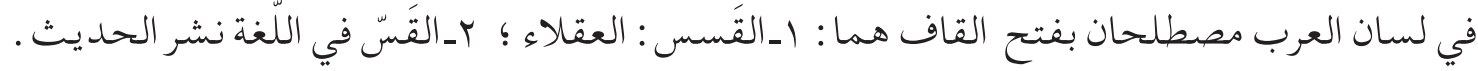

1 ـ ـ حرص محققو النصوص على ضمّ قافه، انظر مثلاً ابن حجر، الإصابة في تميز أسماء الصحابة، 0 / 001، ترجمة رقم

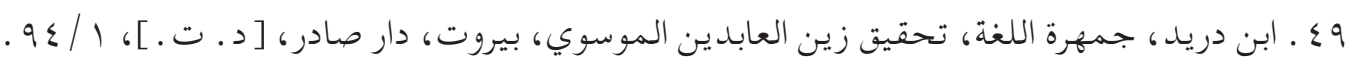

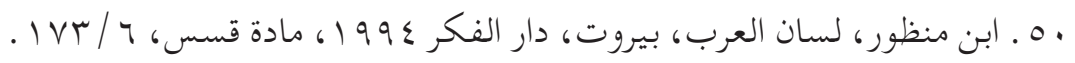

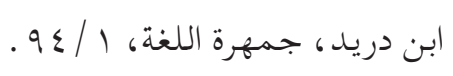

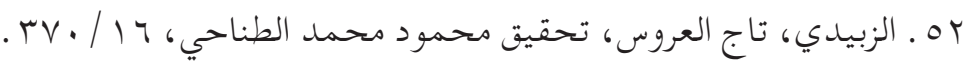

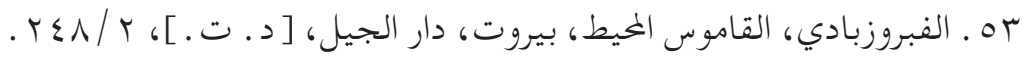

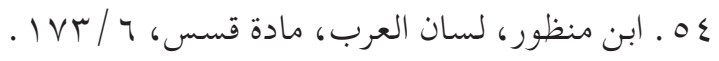




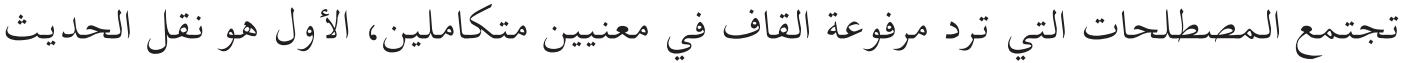

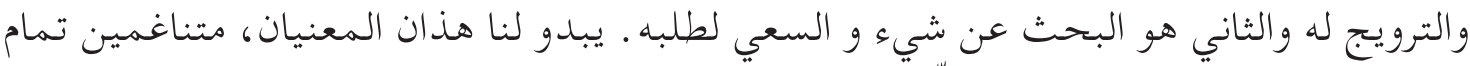

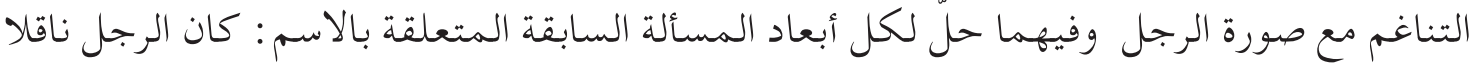

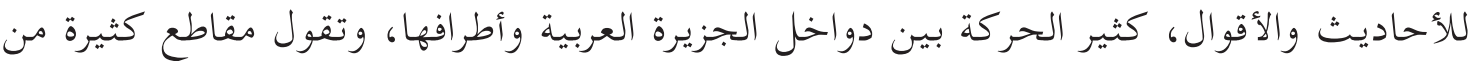

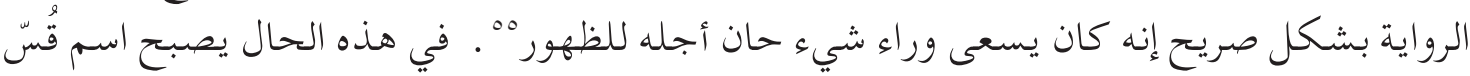

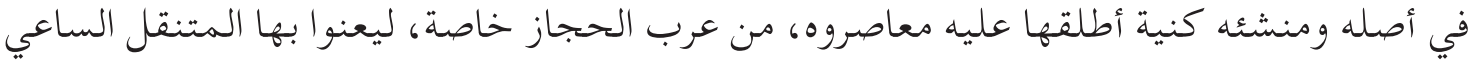

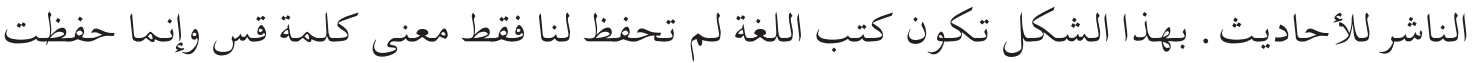

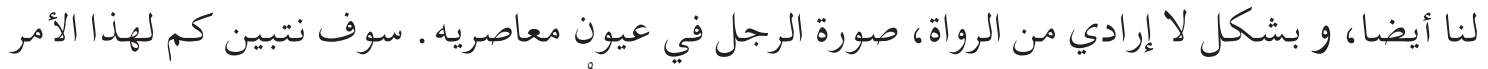

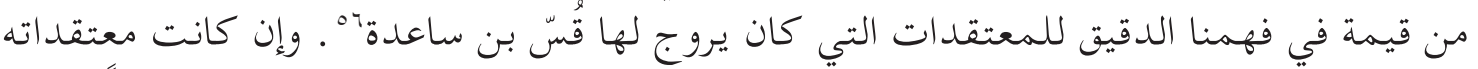

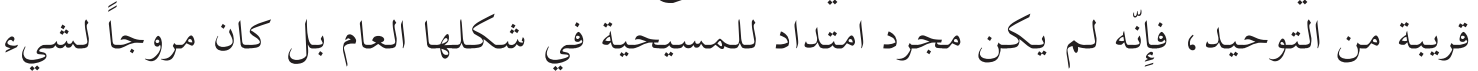

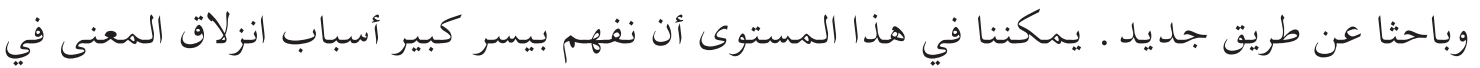

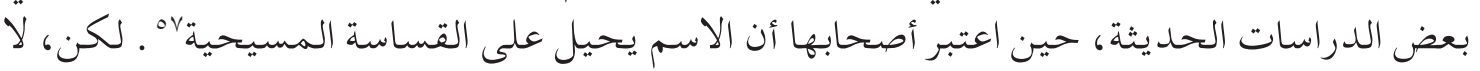

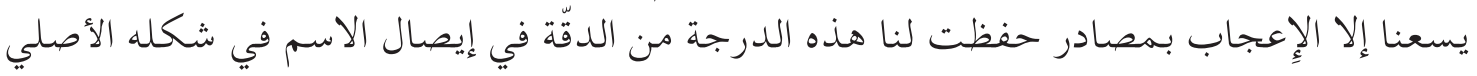

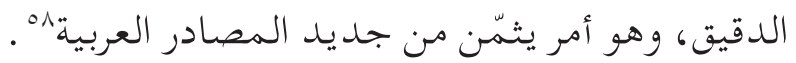

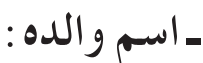

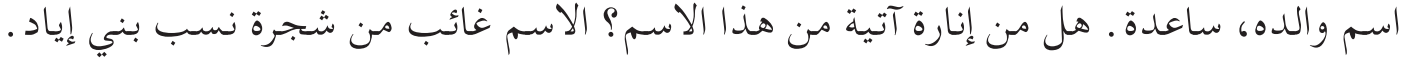

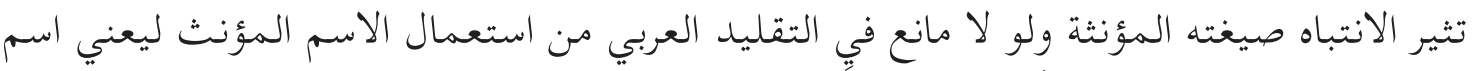

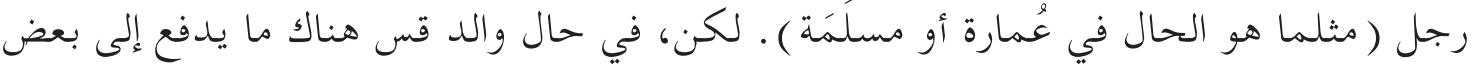

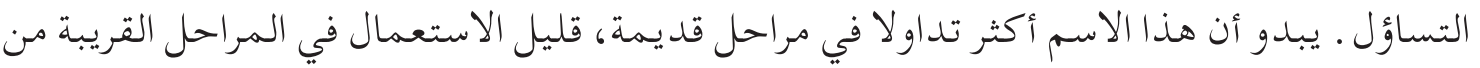

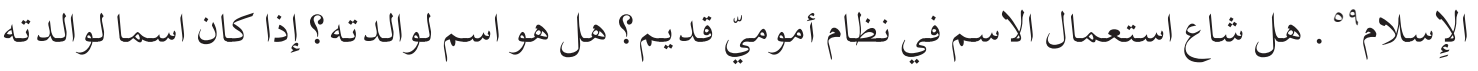

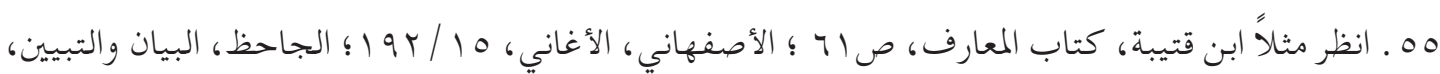
r. $r-r \cdot \Lambda / 1$

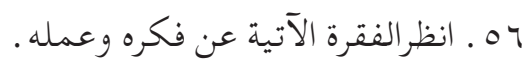
.Pellat (Charles), « Kuss Ibn Sāiida », Encyclopédie de l'Islam, $2^{e}$ édition, V/532 غ̇o V .

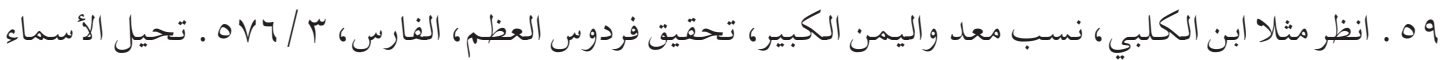

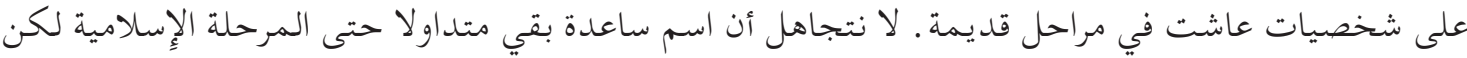

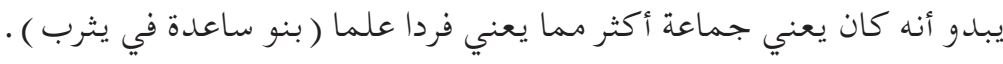


يتقلص أملنا في العثور على أي معلومة في طيّات كتب النّسب، المبنيّة كما هو معلوم على علاقات

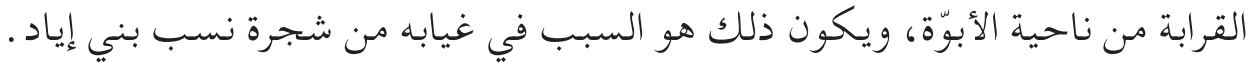

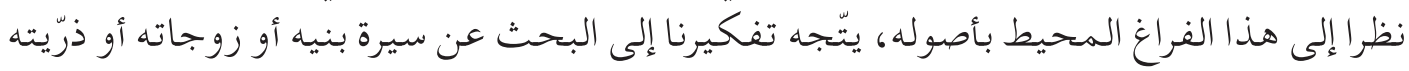

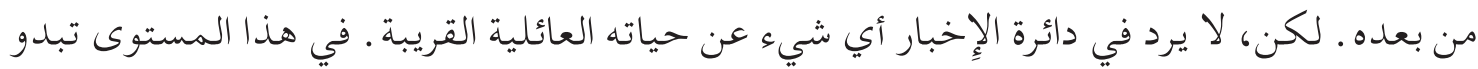

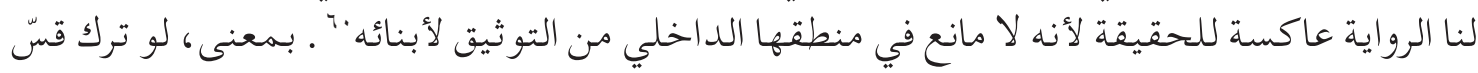

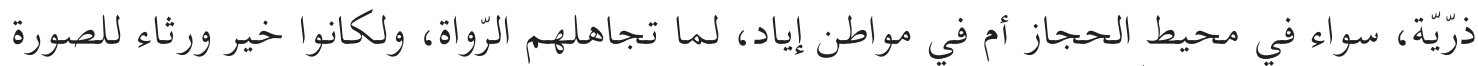

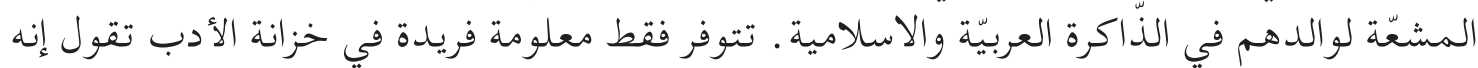

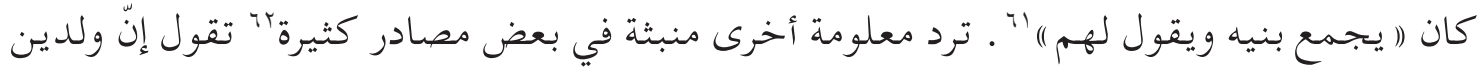

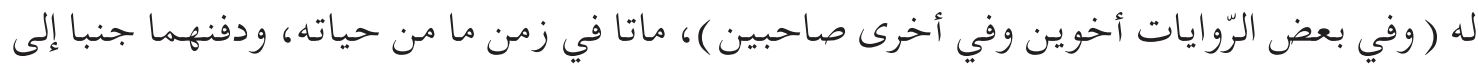

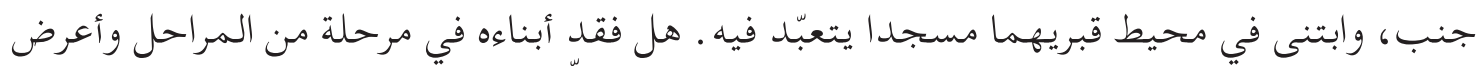

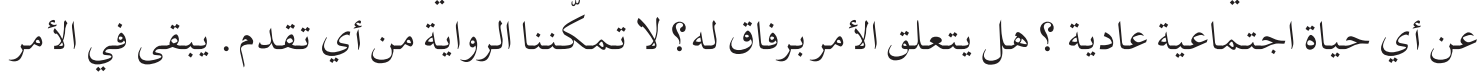

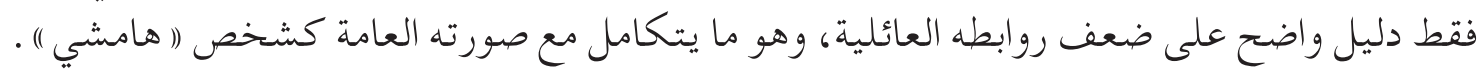

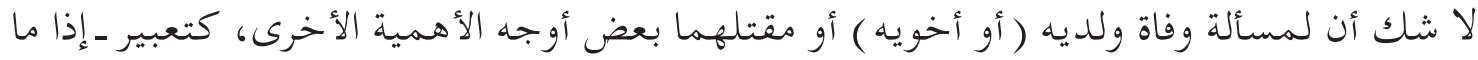

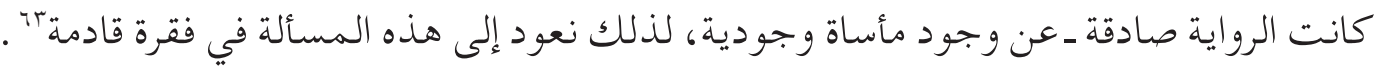

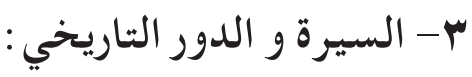

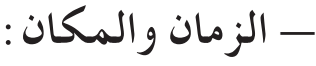
في أي زمان عاش قسّ ؟ ذكرنافي فقرة سابقة أنّ قس دخل دائرة التّأريخ من زاوية الأدب ، و المنظور الأدبي قليل الاكتراث بعنصر الزمان . المرحلة الجاهلية تمثل في وعي الموثقين للأدب زمنا ثقافيا

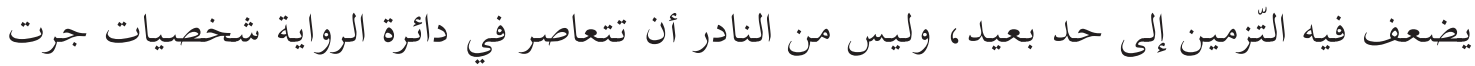

• ا ـ يدفع المنطق الداخلي للرواية العربية الإِسلامية لغبن بعض صلات القرابة مثلما هو الحال في مصاهرات

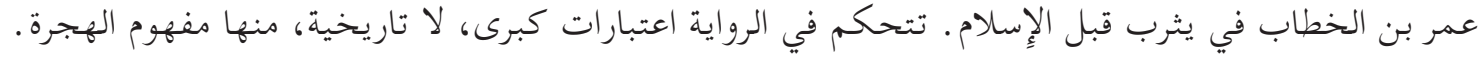

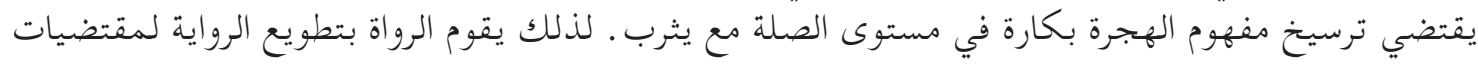

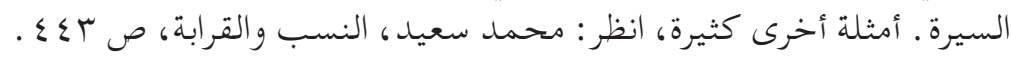

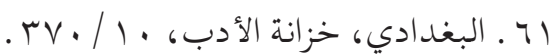

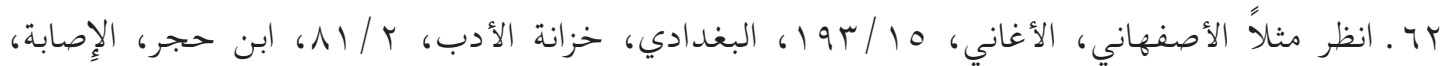

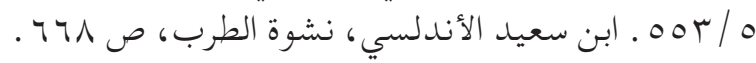

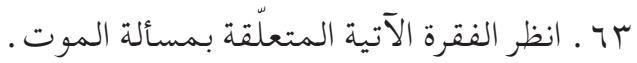




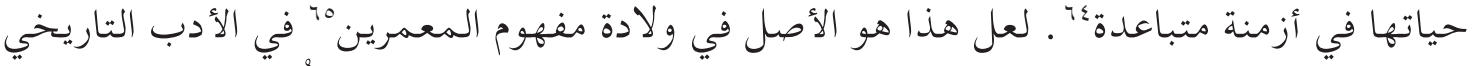

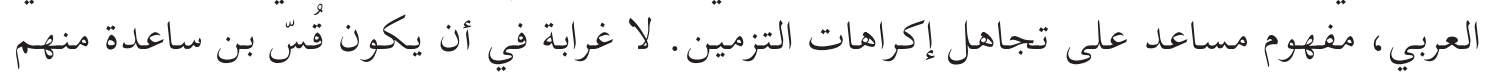

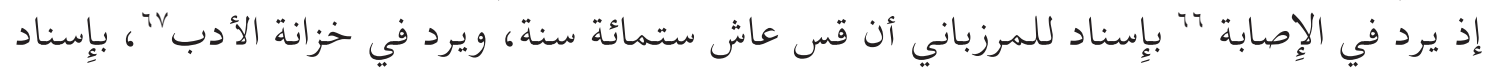

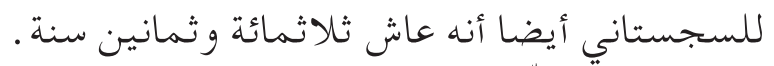

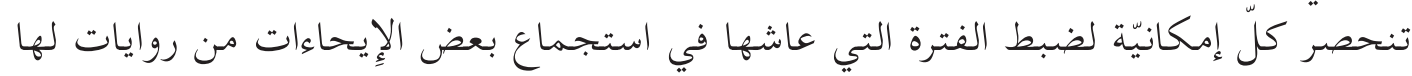

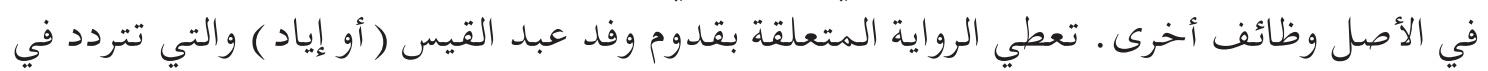

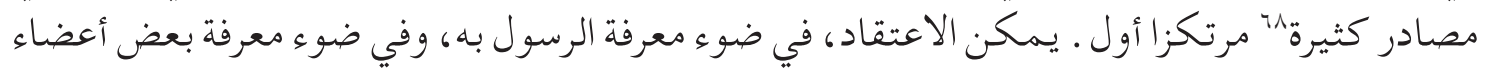

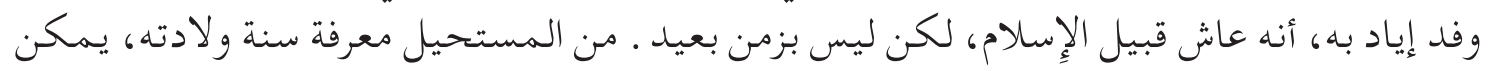

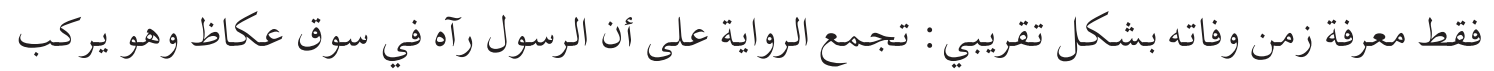

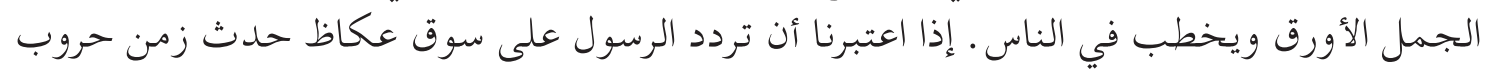

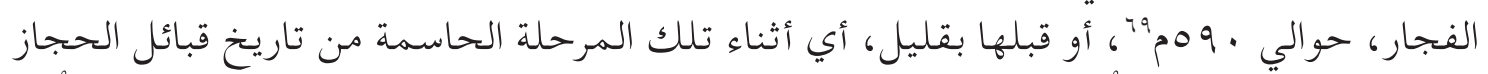

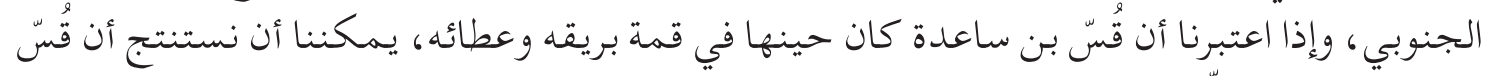

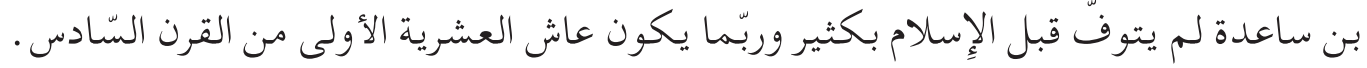

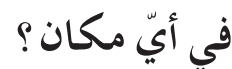

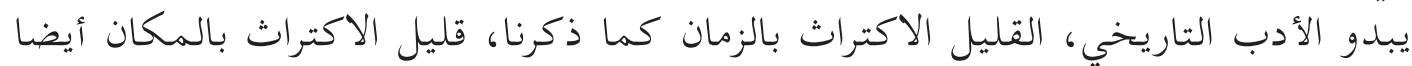

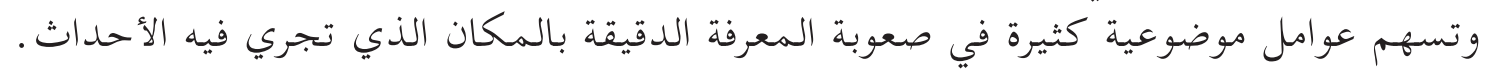

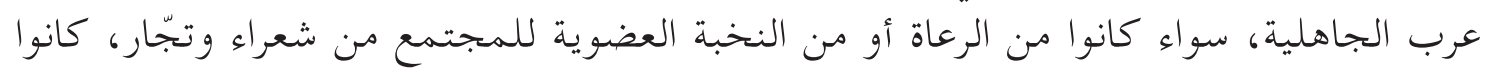

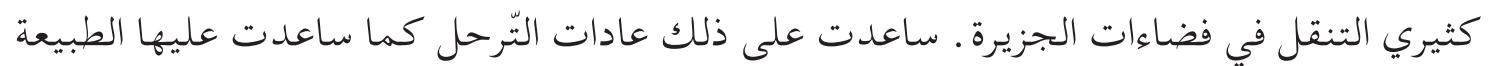

عُ ـ الصكلي (منذر )، (اخواطر حول صورة أهل الردة اليمنيين في المصادر العربية الإسلامية)، كراسات

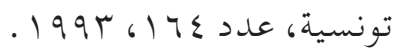

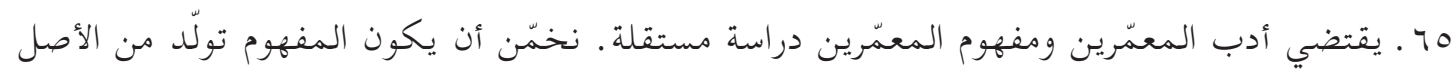

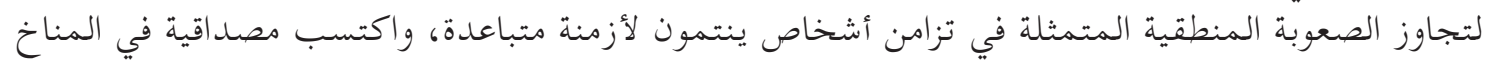

$$
\text { الذهني للعصر الوسيط. }
$$

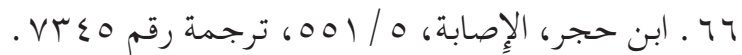

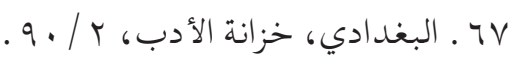

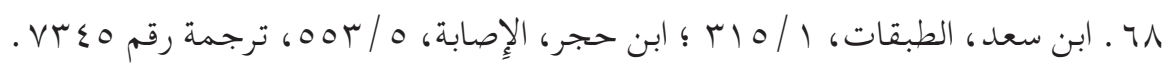

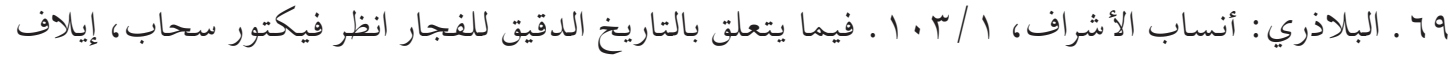

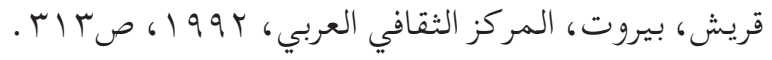


الجغرافية المفتوحة لفضاءات الجزيرة والدرجة المتقدمة من الانفتاح الإِنساني التي كانت بدورها

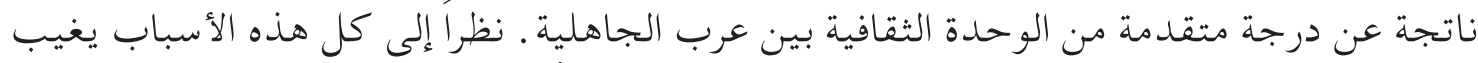

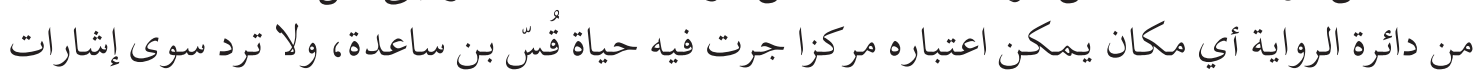

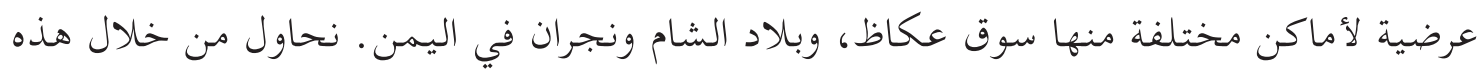

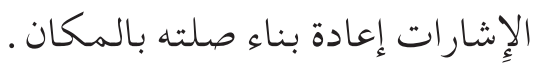

\section{عكاظ :}

حفظت الرواية حضوره في سوق عكاظ. هل كان مقيما في محيطه؟ الأقرب إلى التصور أن

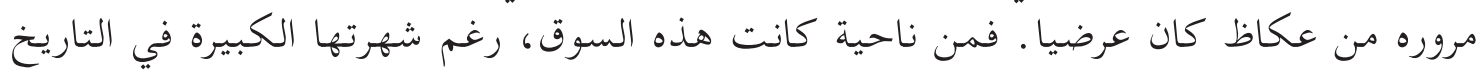

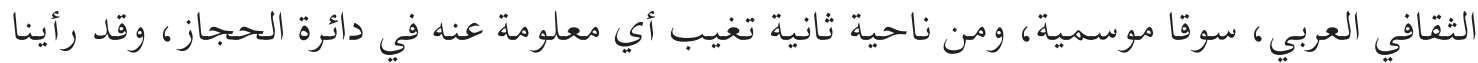

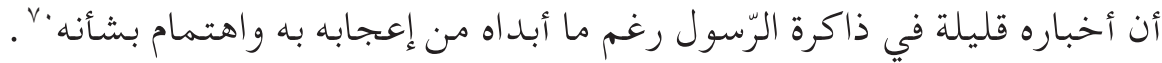
لأيّة غاية كان يرتاد عكاظ؟

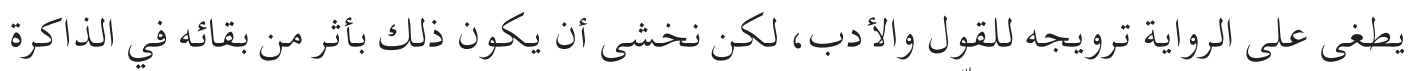

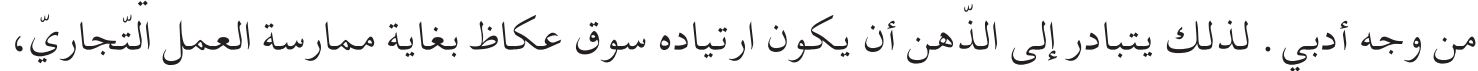

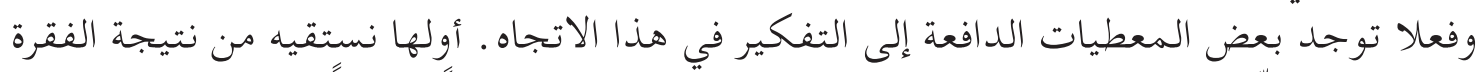

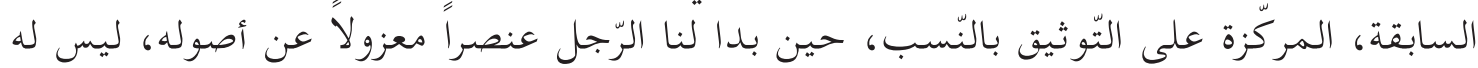

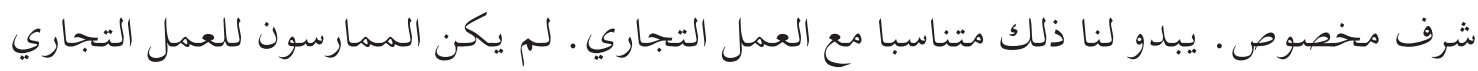

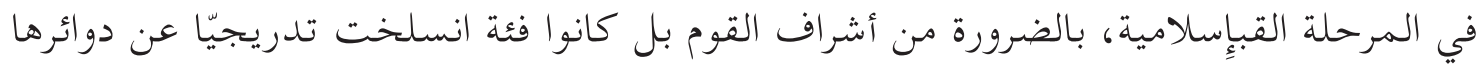

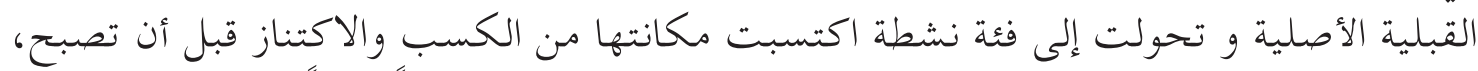
في مرحلة قريبة من الإِسلام، حاملة لمستقبل المجتمع . لا نسجل نشاطاً كبيراً في التجارة لأشراف

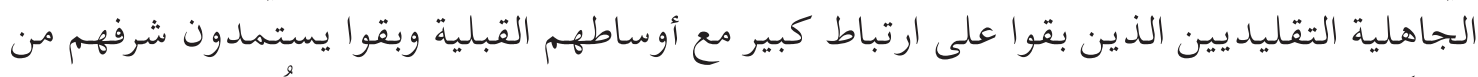

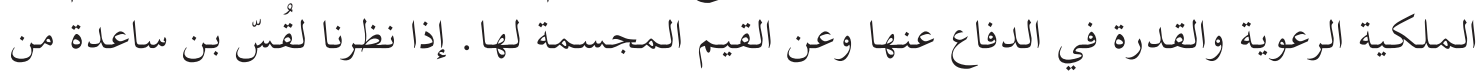

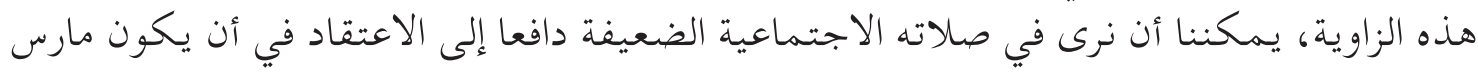

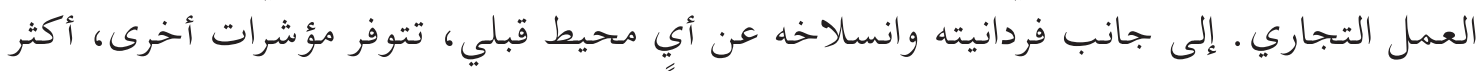

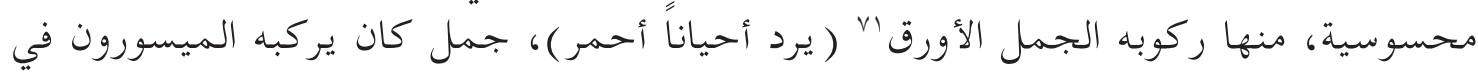

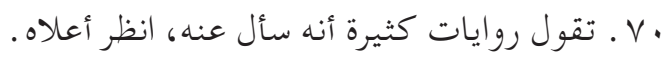
( مادي اللون 


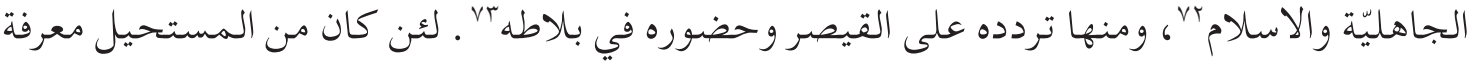

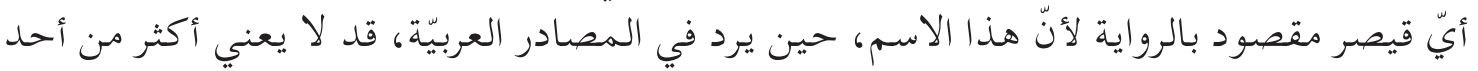

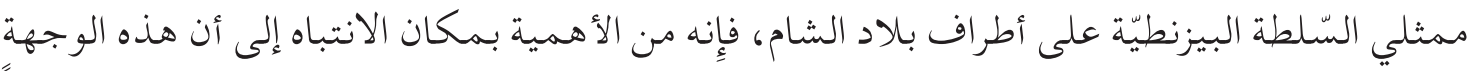

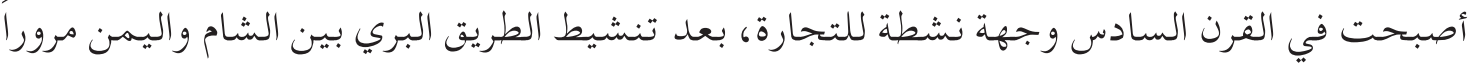

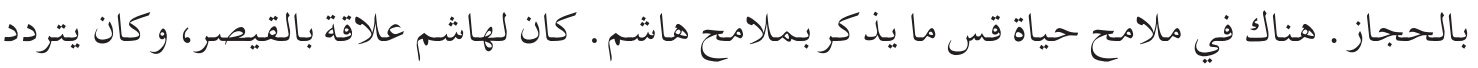

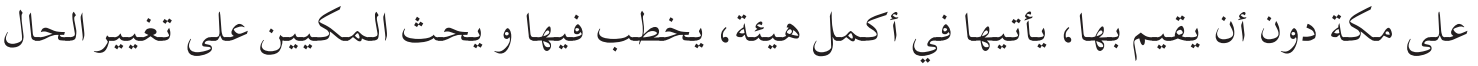

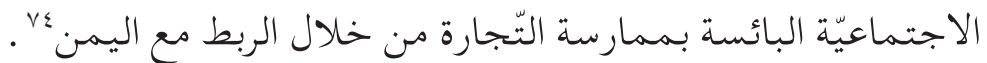

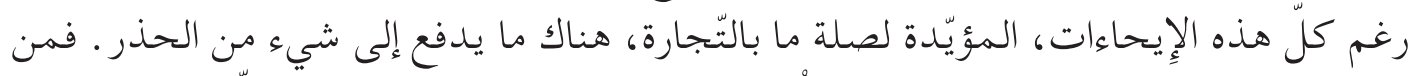

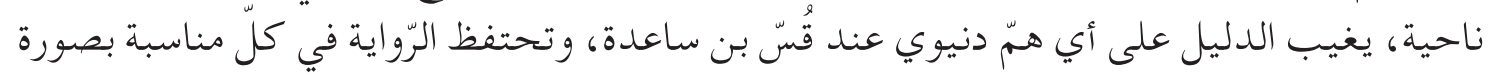

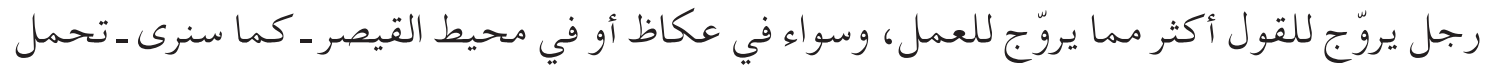

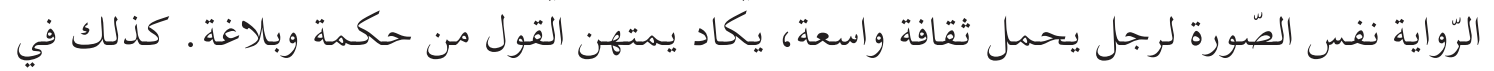

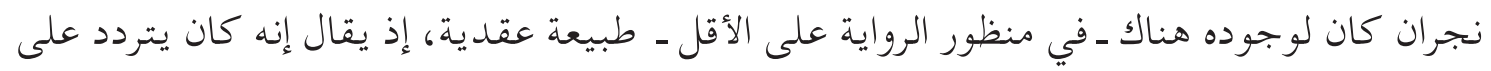

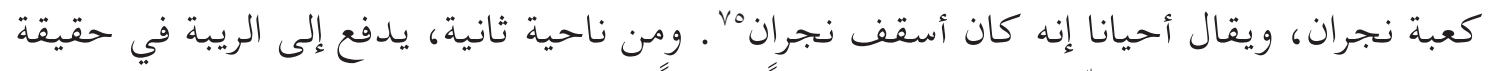

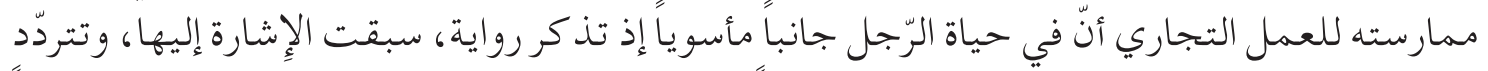

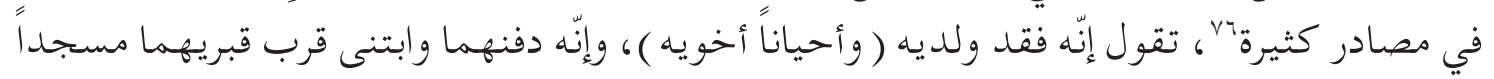

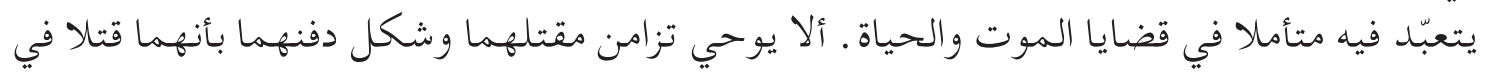

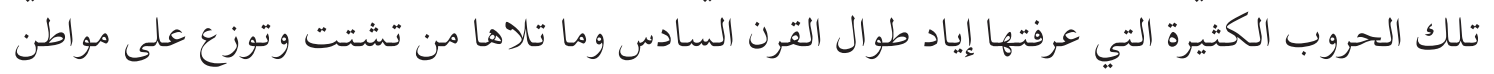

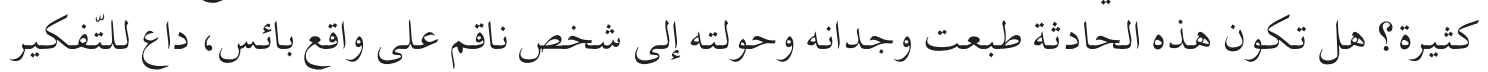

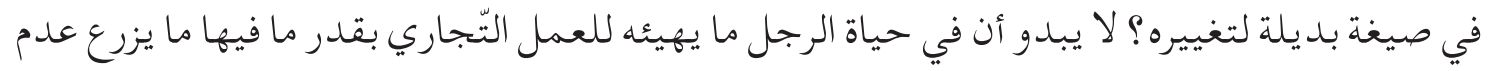

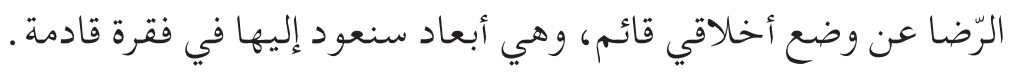

Tr. V نبهنا الأستاذ منذر الصكلي إلى أنّ المصادر تقول إنّ الرسول محمد في حجة الوداع كان يركب الجمل

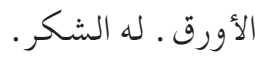

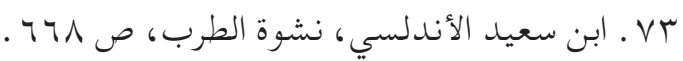

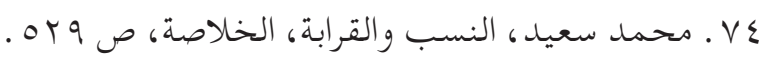

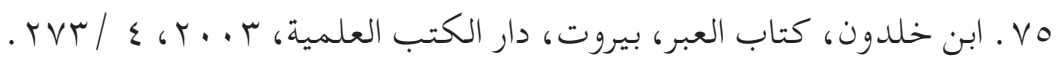

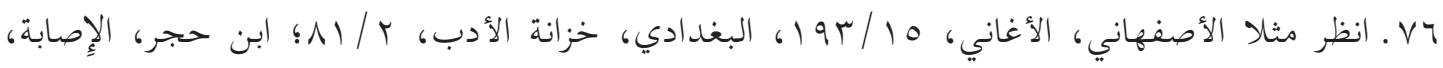

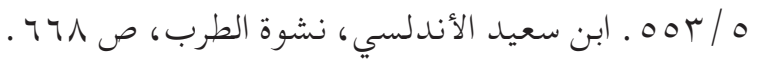




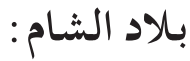

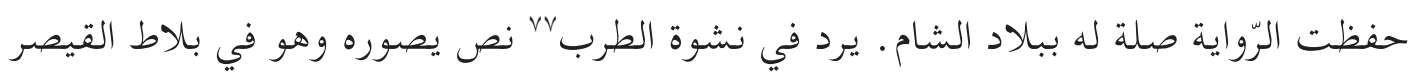

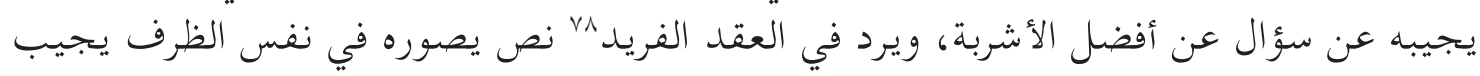

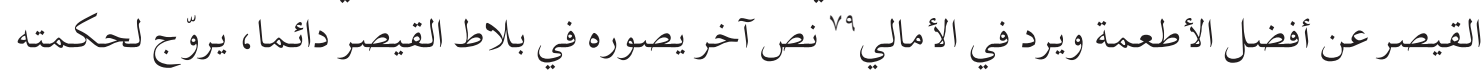

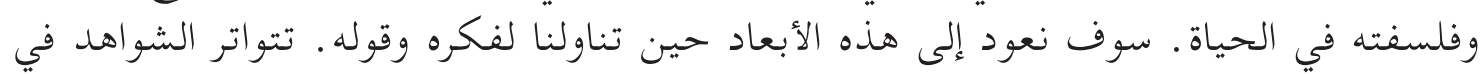

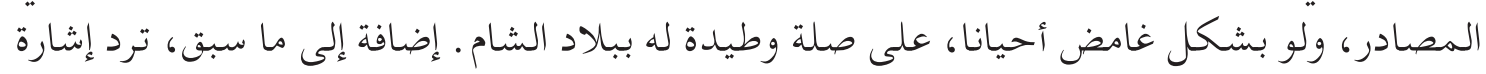

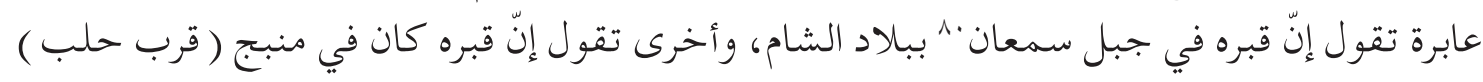

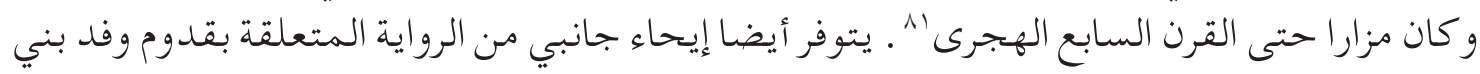

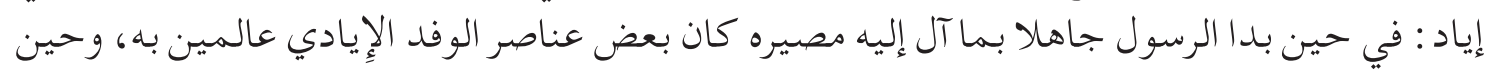

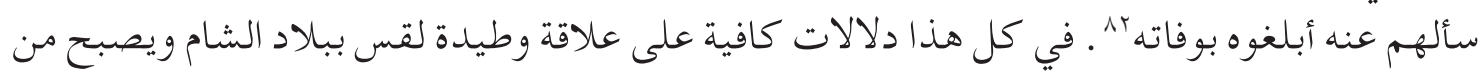

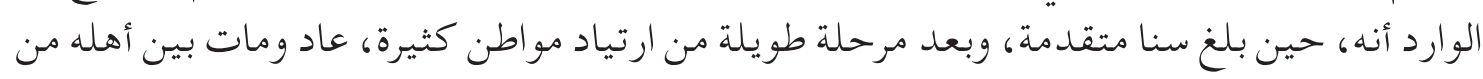

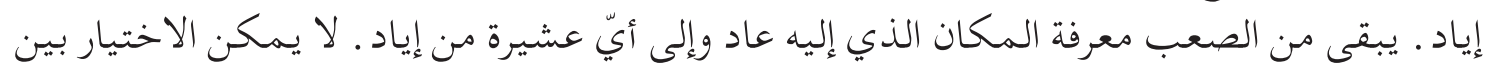

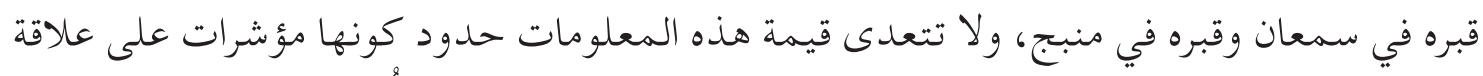

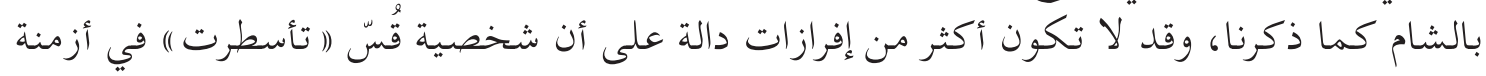

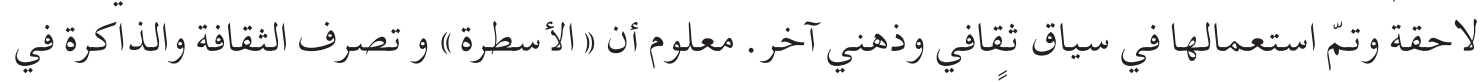

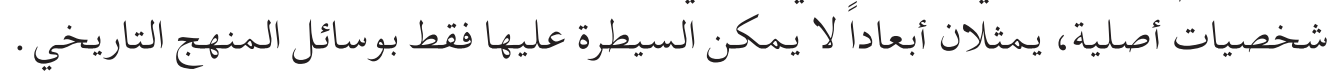

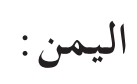

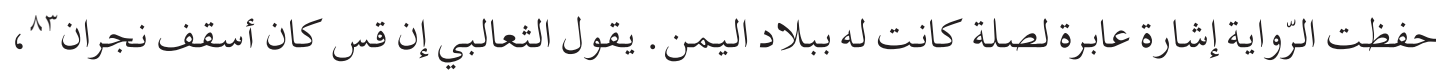

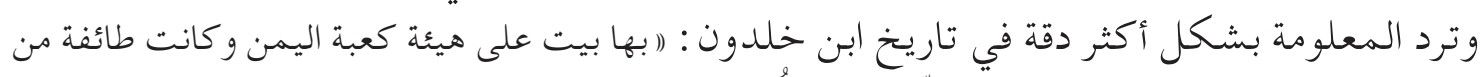

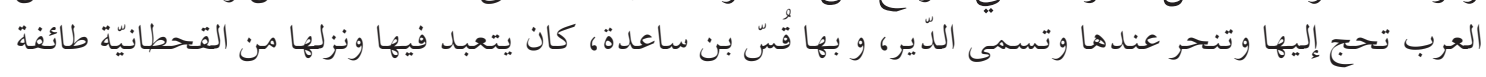

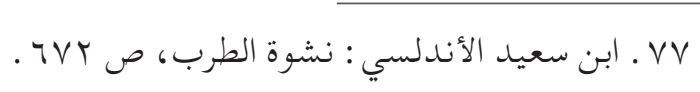

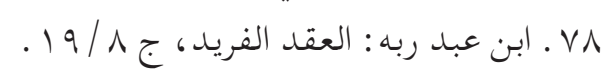

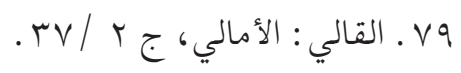

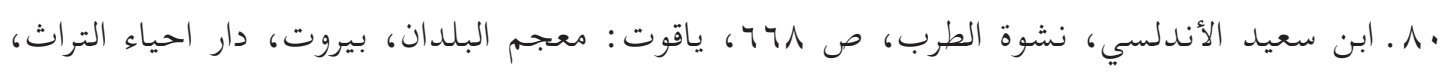

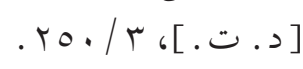

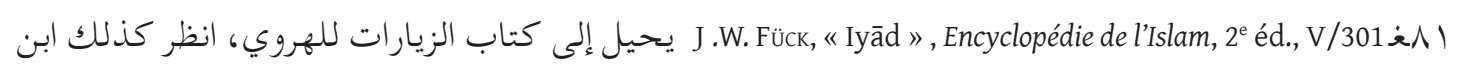

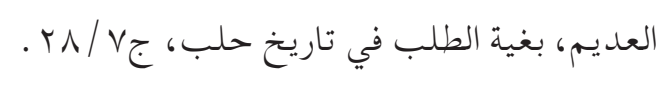

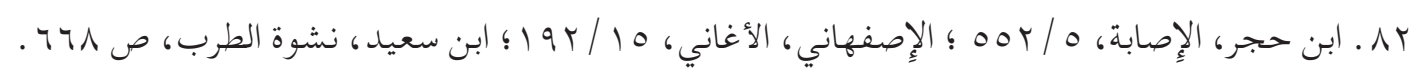

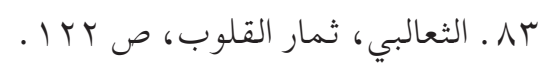




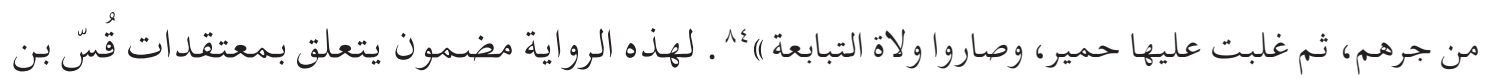

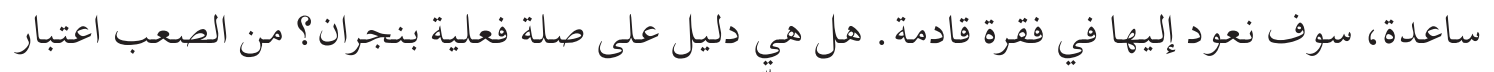

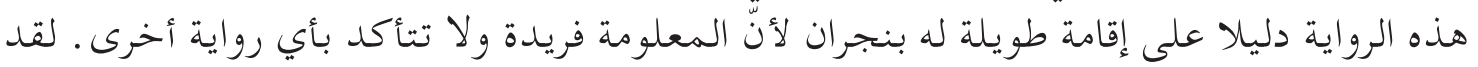

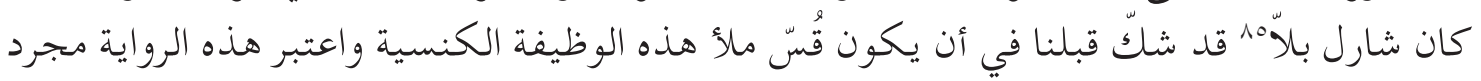

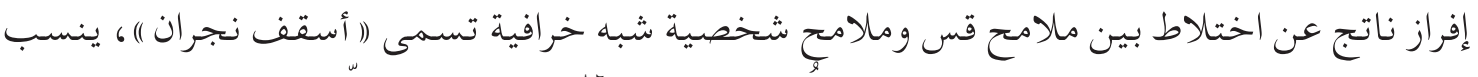

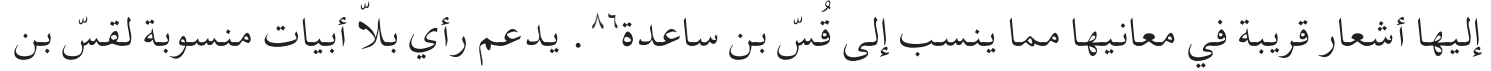

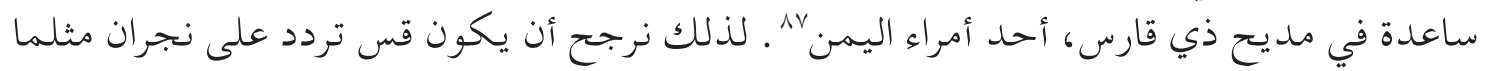
تردد على عكاظ. لا تتيح الرواية يقينا أكبر .

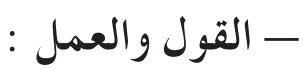

انقطاع عن الوسط القبليّ، رحلات إلى بلاد الشّام و إلى عكاظ ونجران دون دلائل على ممارسة

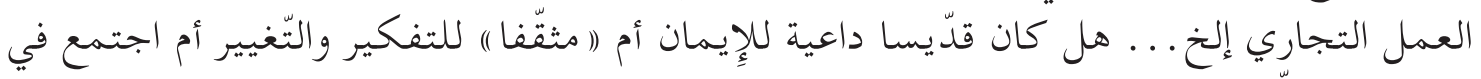

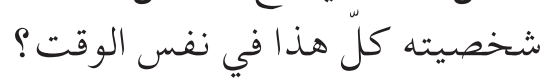
لا مبالغة في القول من جديد أن لا شيء يساعد على الوصول إلى الى الصورة التاريخية الأصلية.

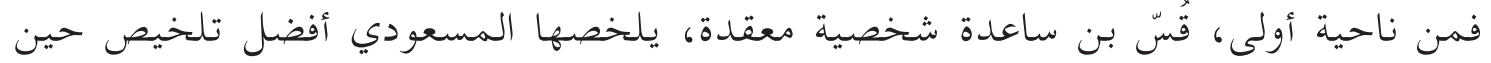

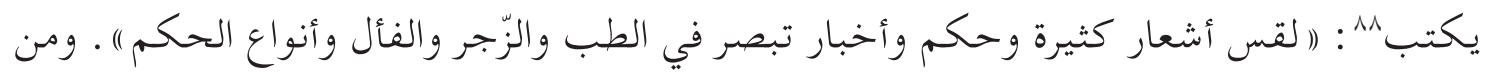

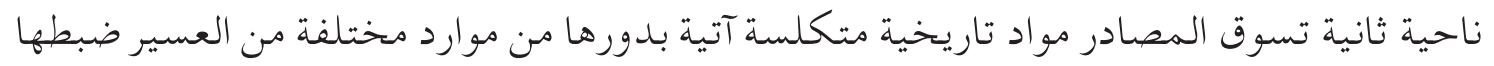

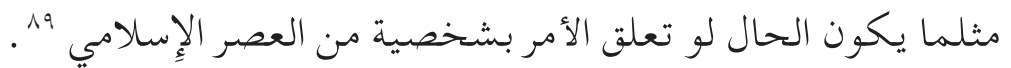

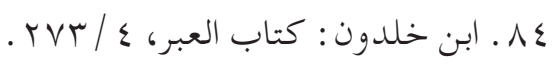
J.W. Fück, « Iyād », Encyclopédie de l'Islam, 2éd., V/301. غ غ ०

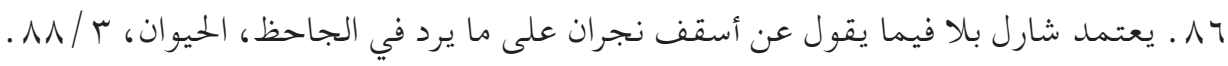

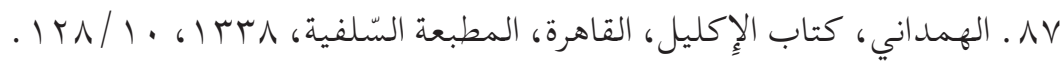

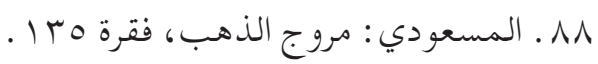

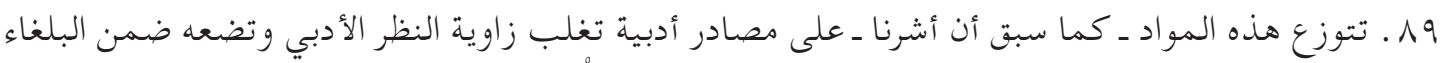

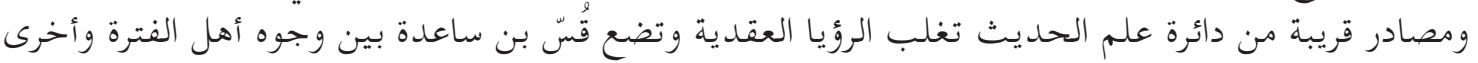

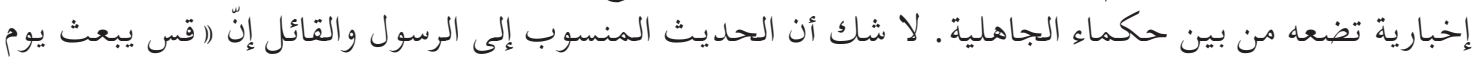
القيامة أمة وحده ) قد مارس ضغطا كبن حبيرا على الرواية. 
تؤكد المعادر كثيراً، هلى خطبته في سوق عكاظ، وترد الخطبة بالكثير من الفروق، ربما

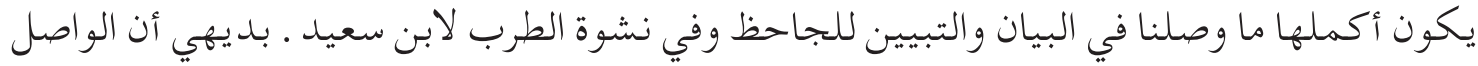

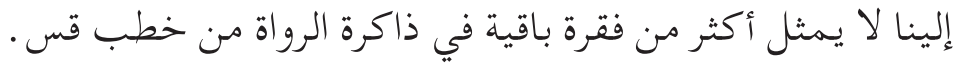

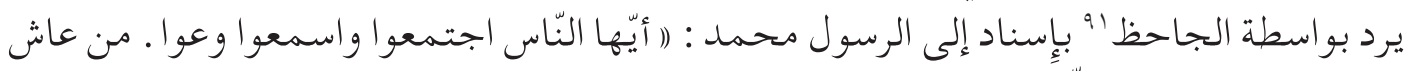

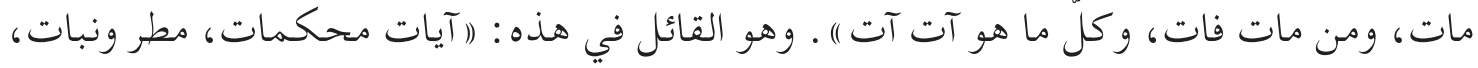

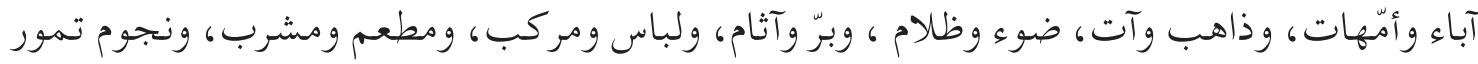

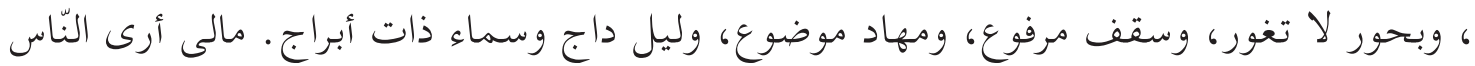

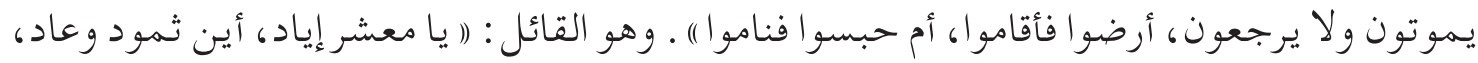

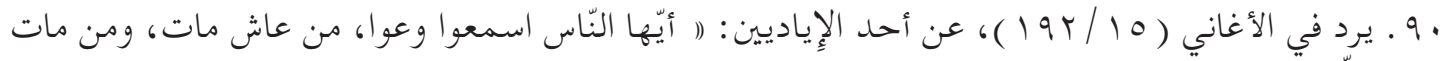

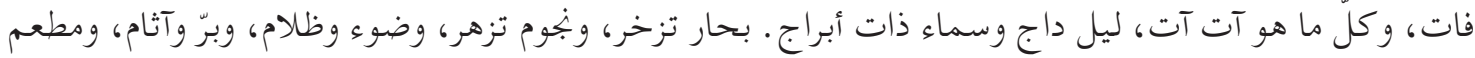

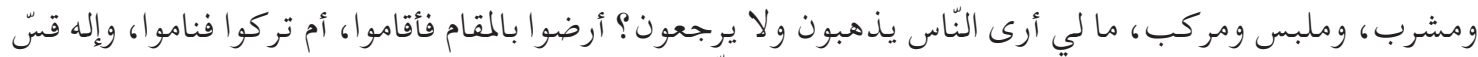

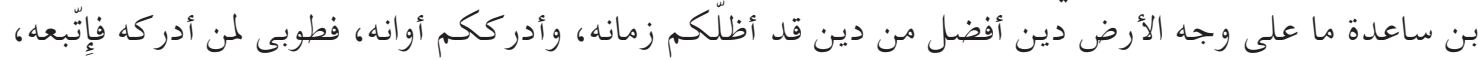

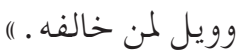

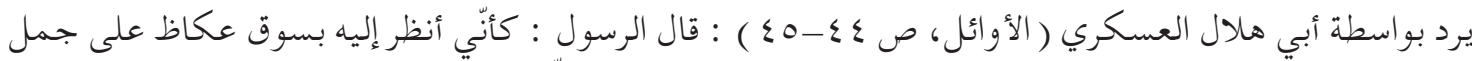

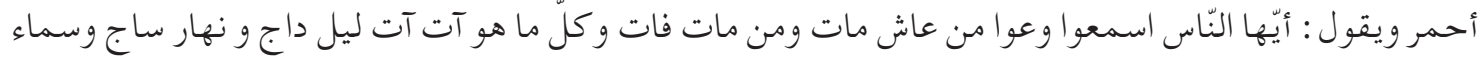

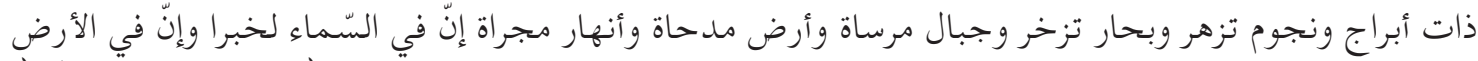

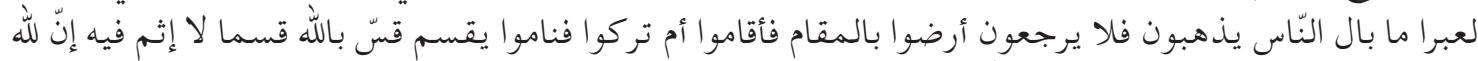

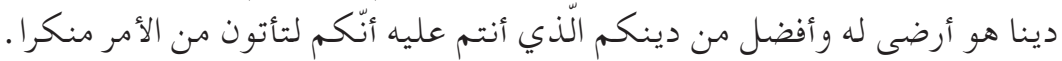

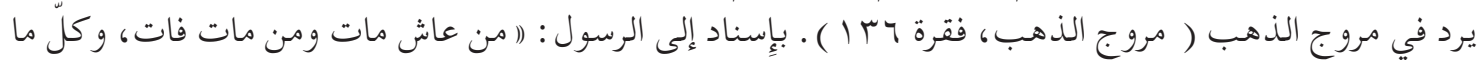

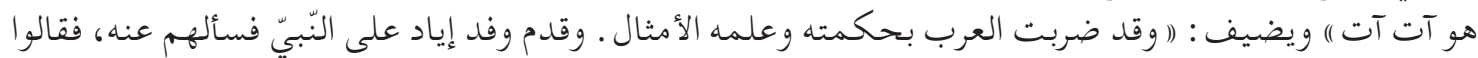

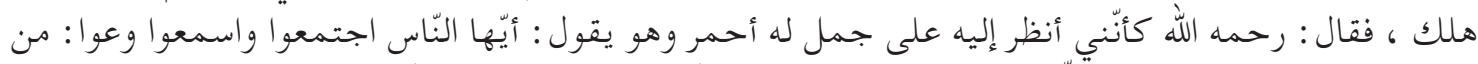

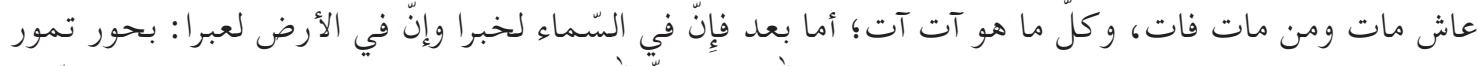

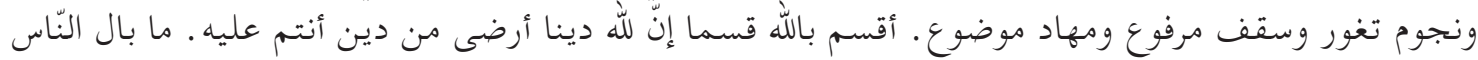

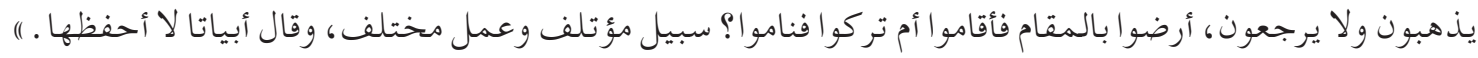

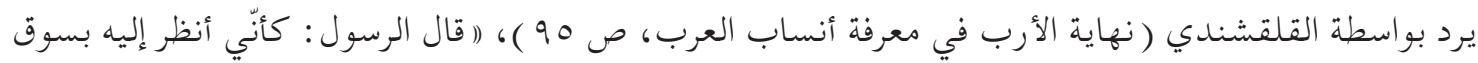

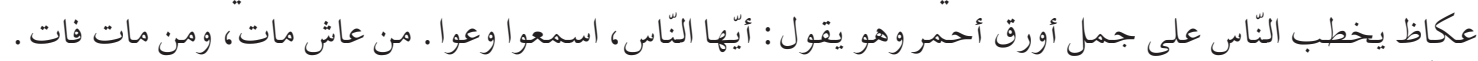

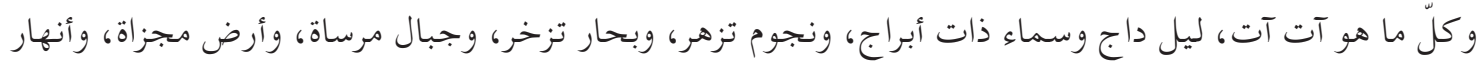

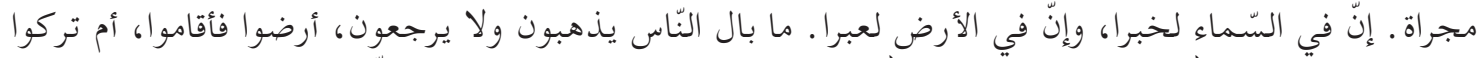

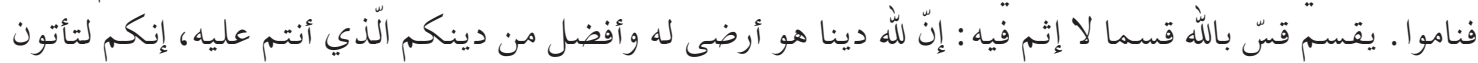

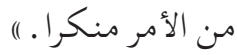

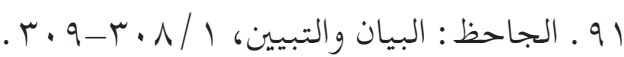


وأين الآباء والأجداد ـ أين المعروف الّذي يشكر، والظّلم الّذّي لم ينكر .أقسم قسّ قسما بالله، إنّ إنّا

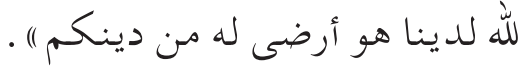

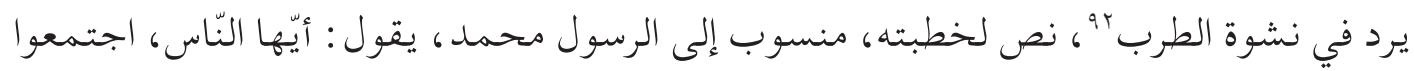

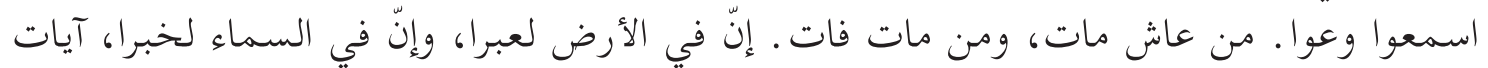

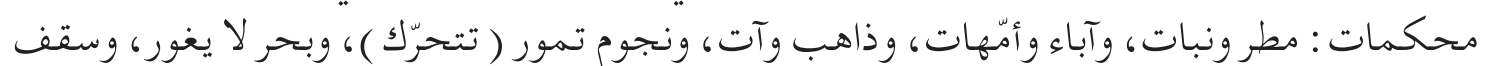

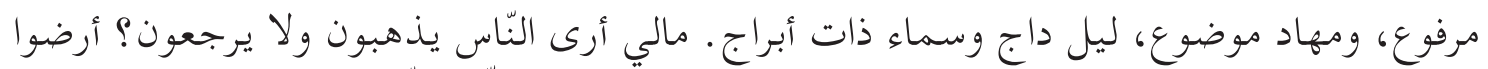

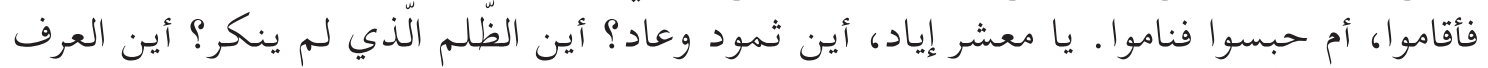

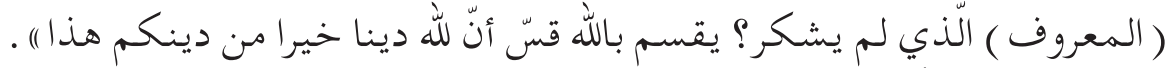

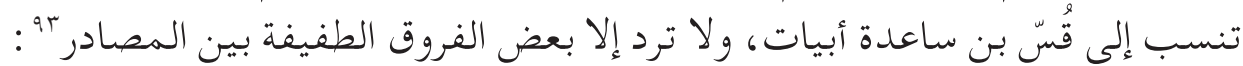

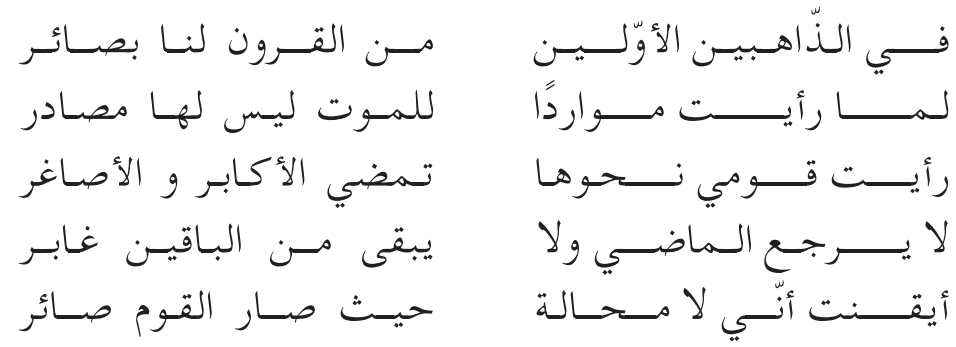

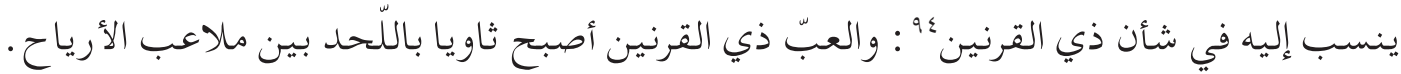

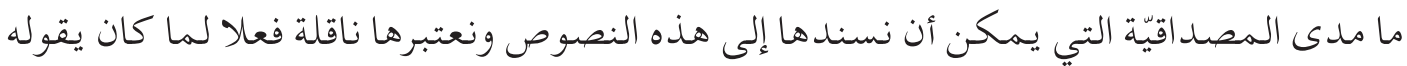

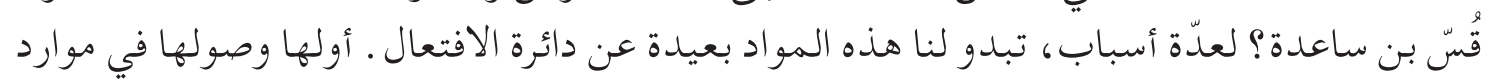

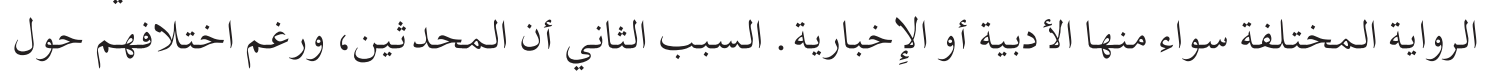

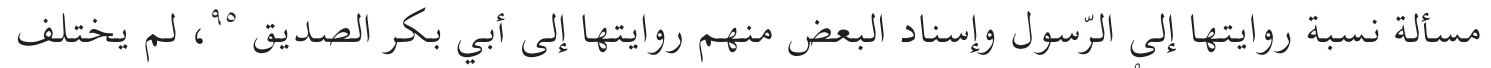

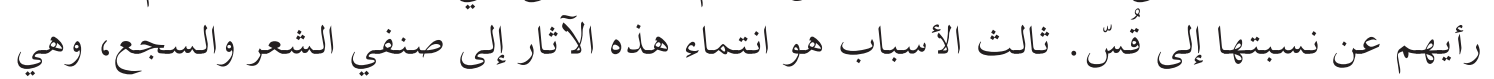

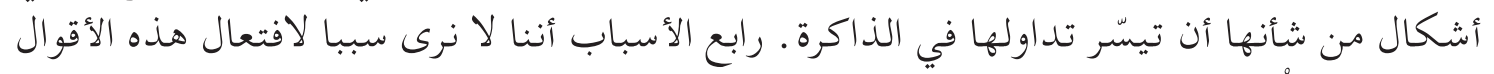

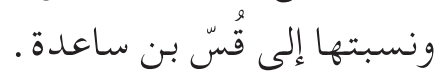

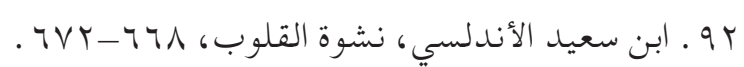

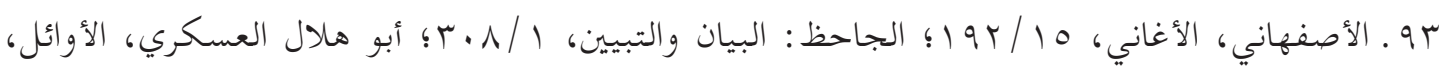

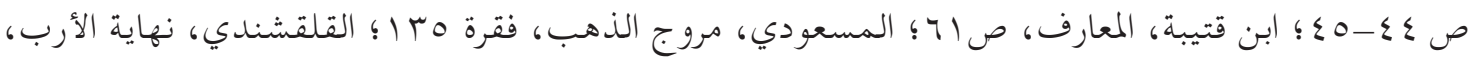

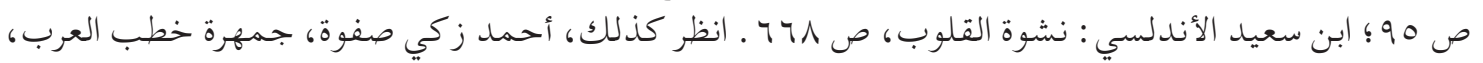

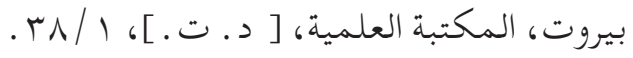

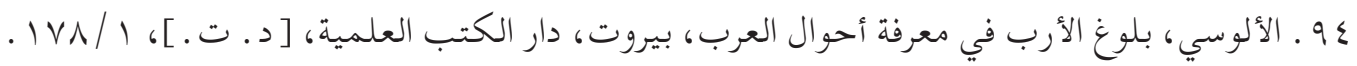
90 . انظر الفقرة الأخيرة المتعلقة بمنطق الرواية. 


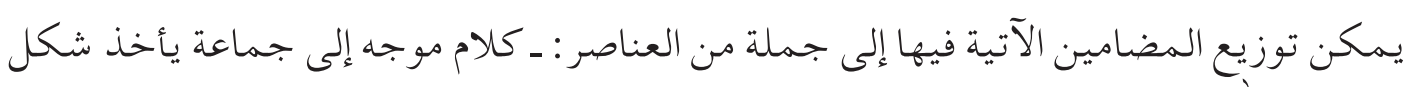

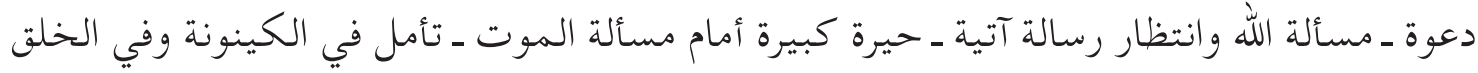
والطبيعة -..

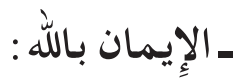

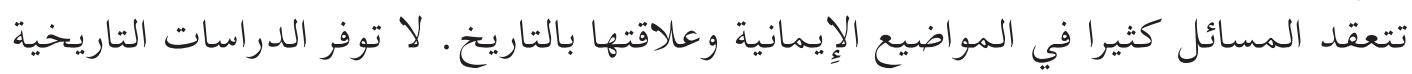

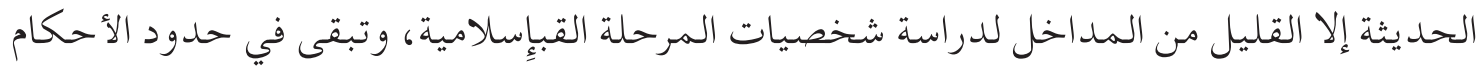

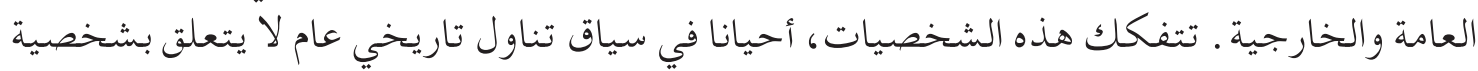

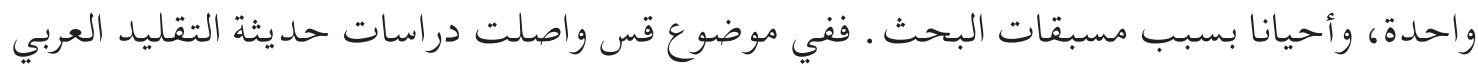

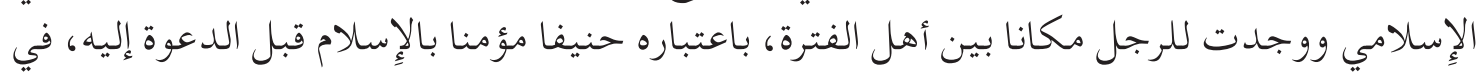

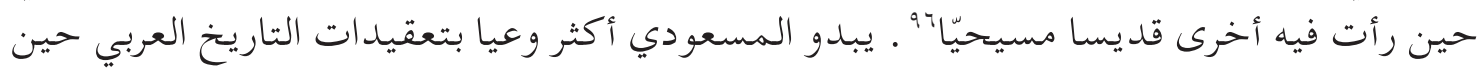

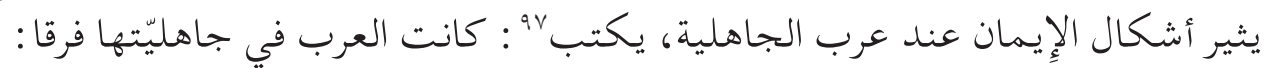

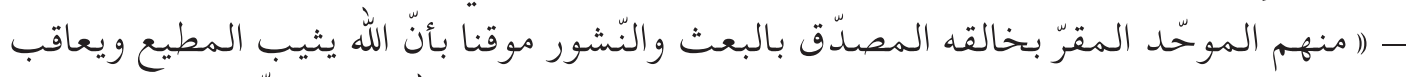

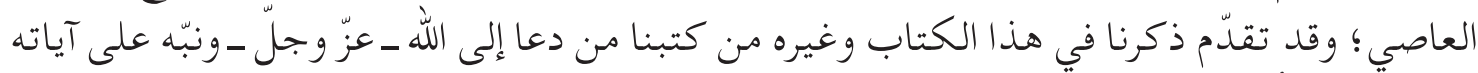

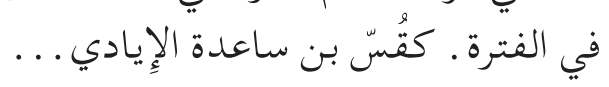

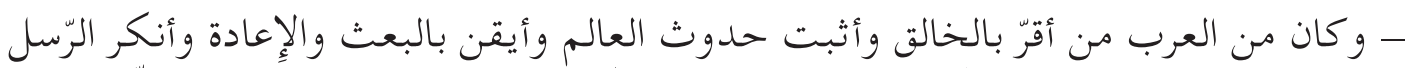

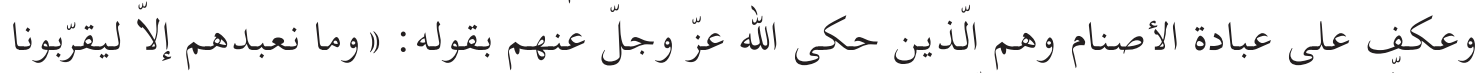

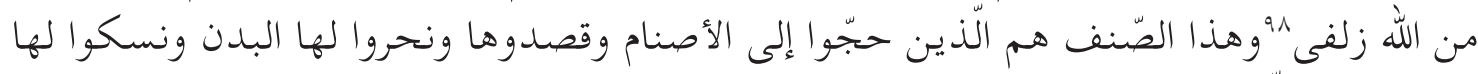

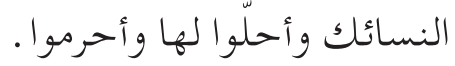

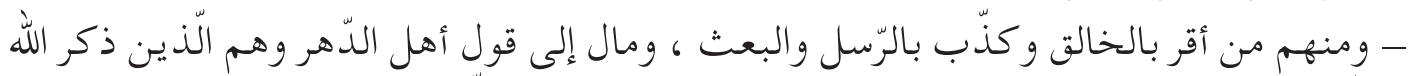

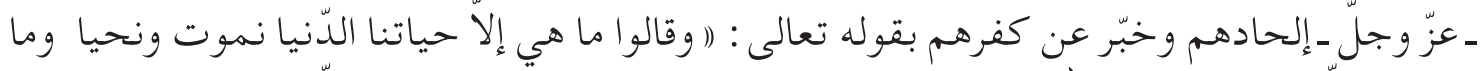

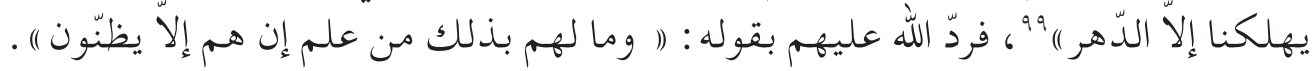

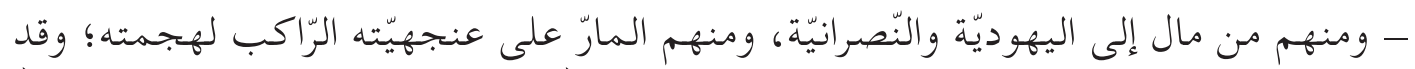

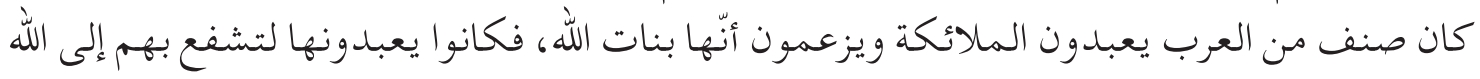

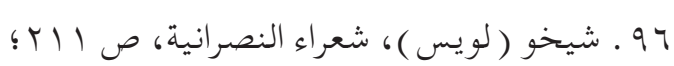
.Pellat (Charles), « Kuss Ibn Sāiida », Encyclopédie de l'Islam, 2e éd., V/532

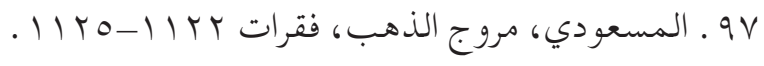

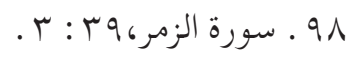

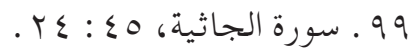




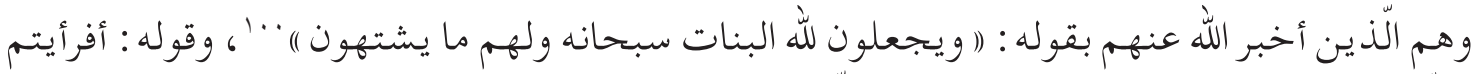

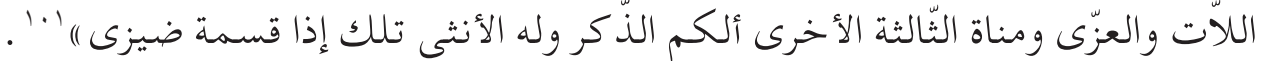

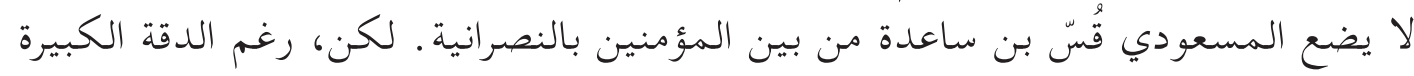

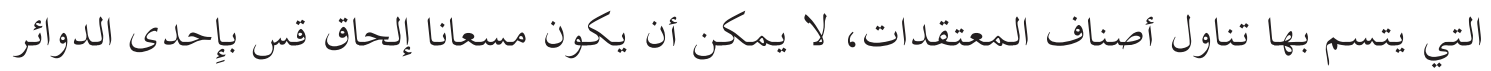

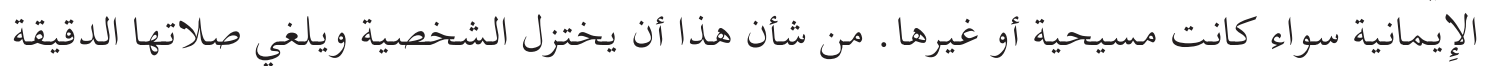

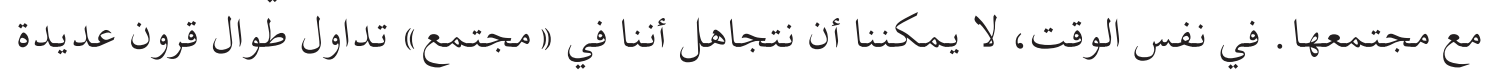

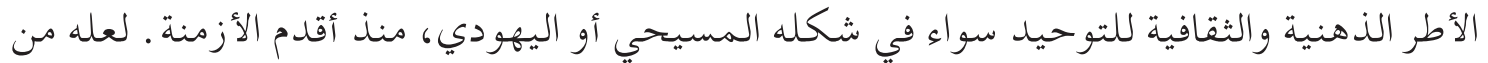

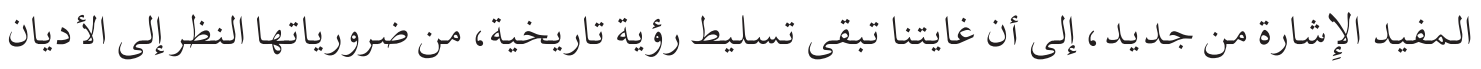

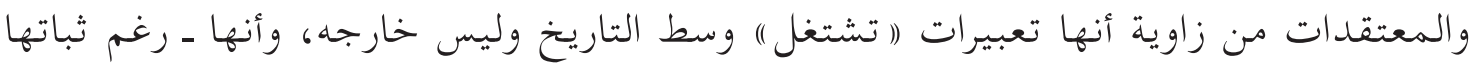

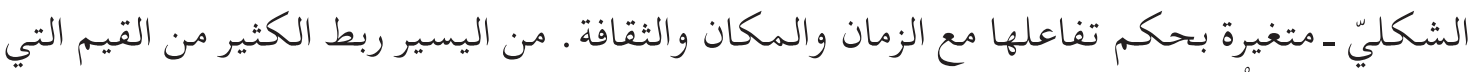

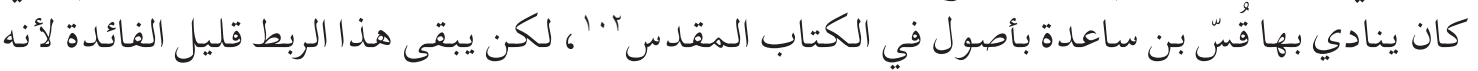

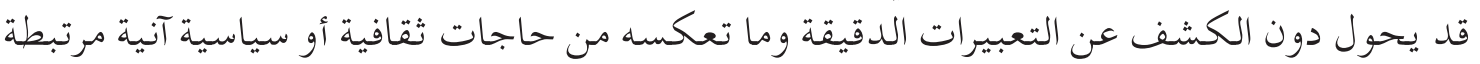

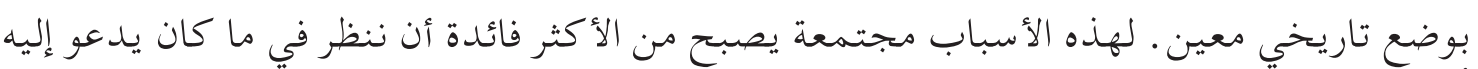

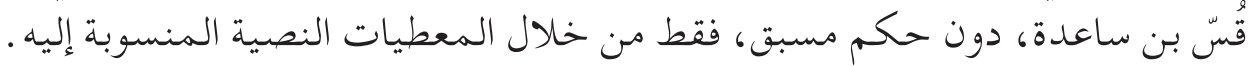

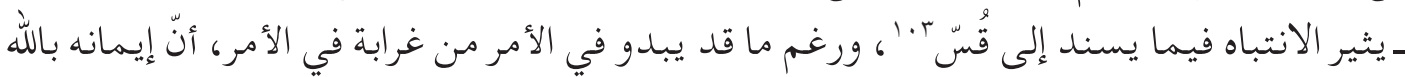

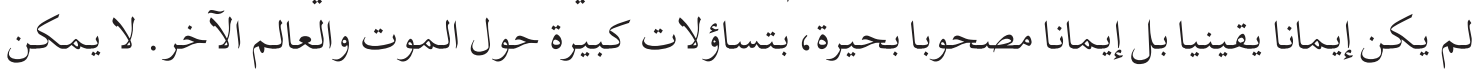

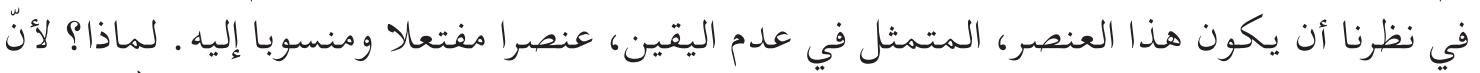

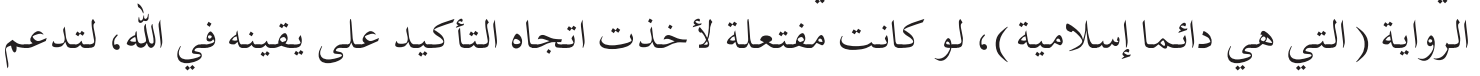

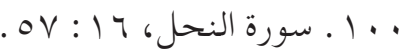

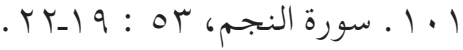

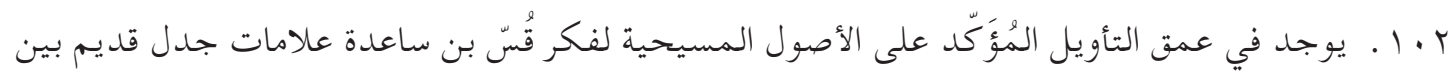

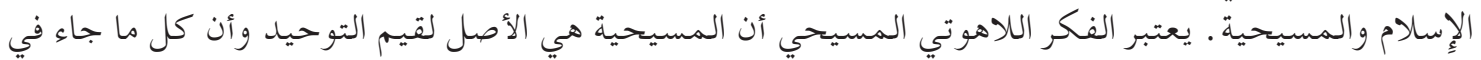

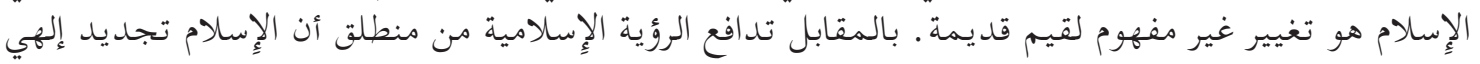

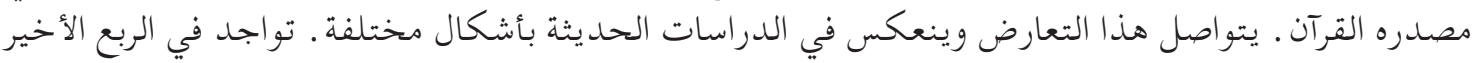

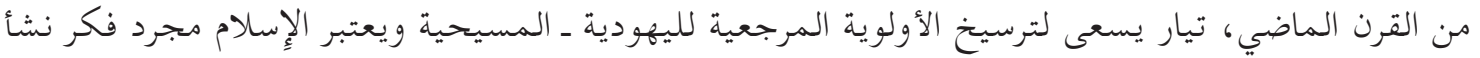

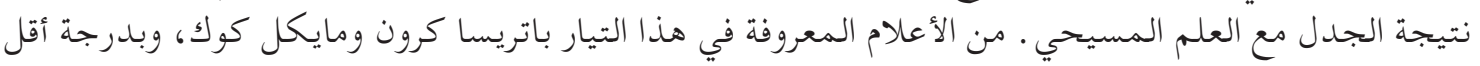

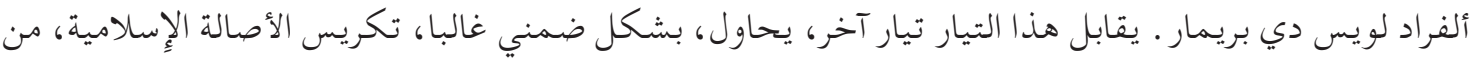

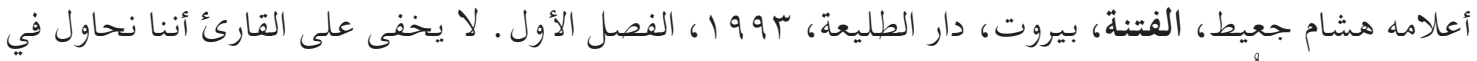

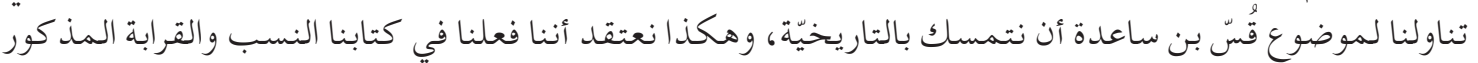




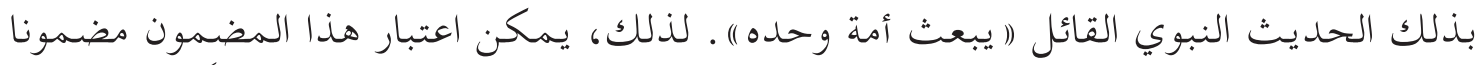

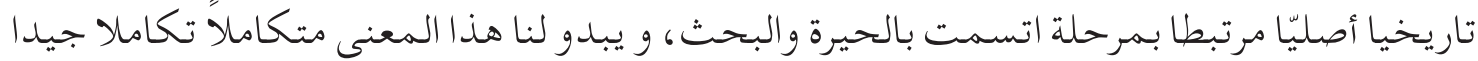

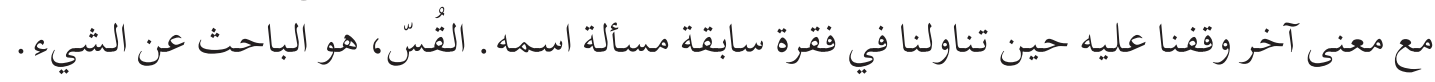

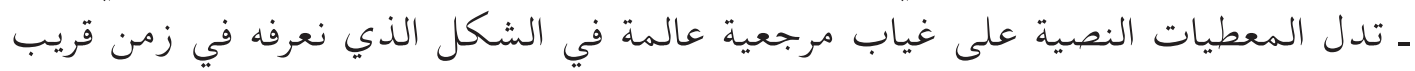

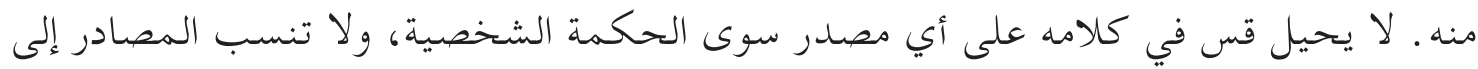

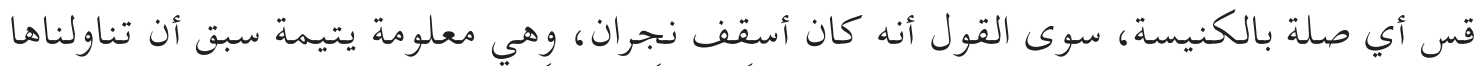

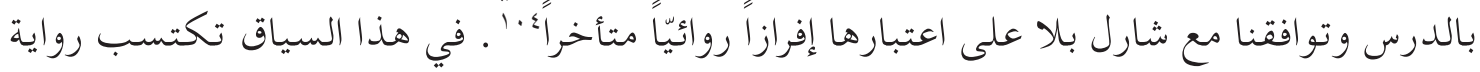

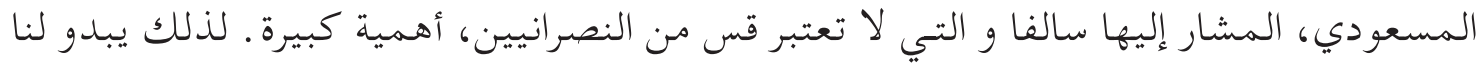

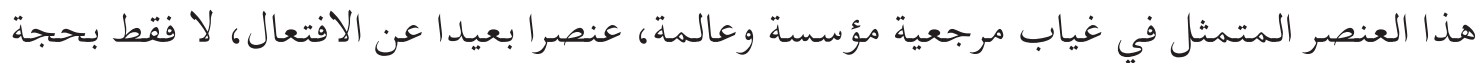

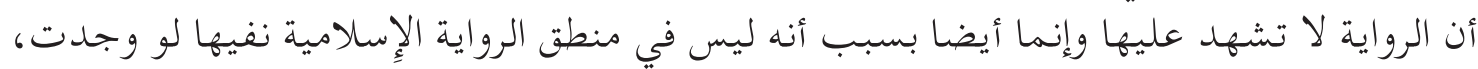

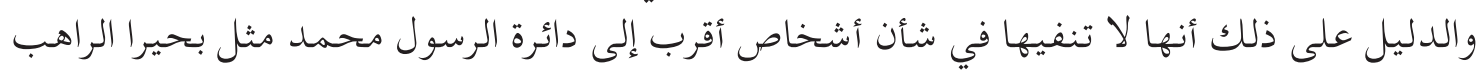

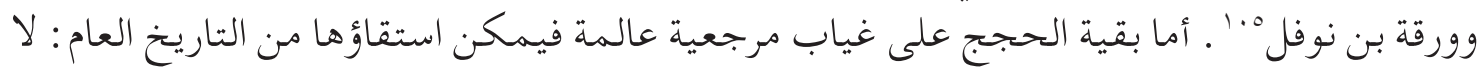

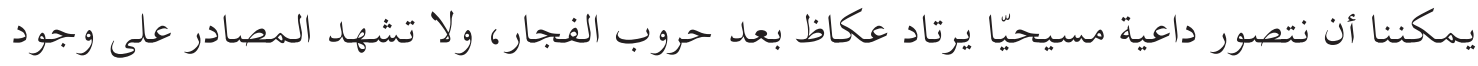

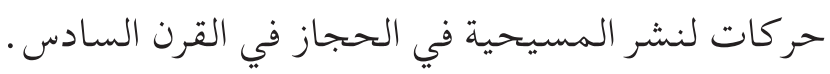

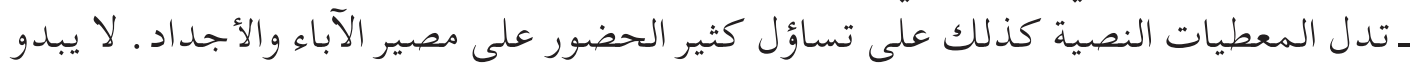

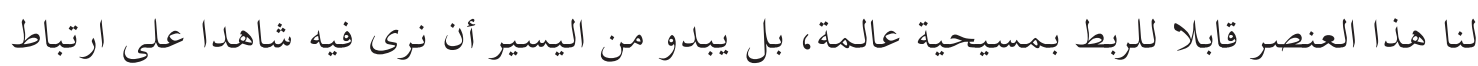

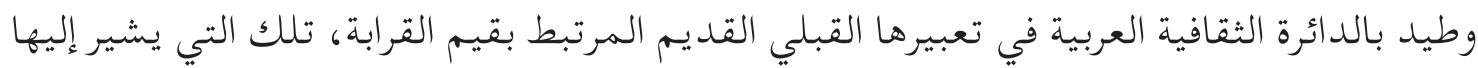

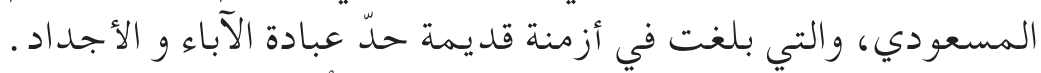

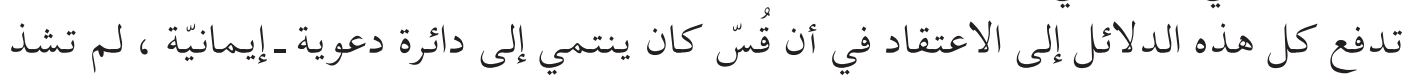

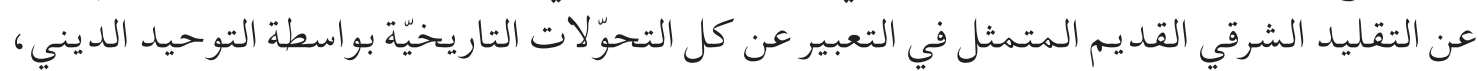

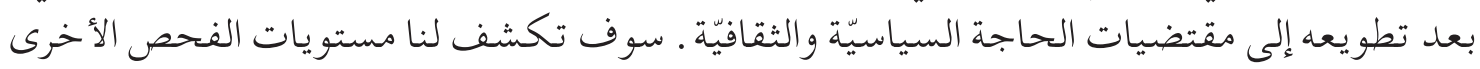

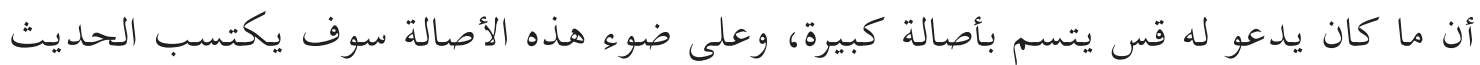

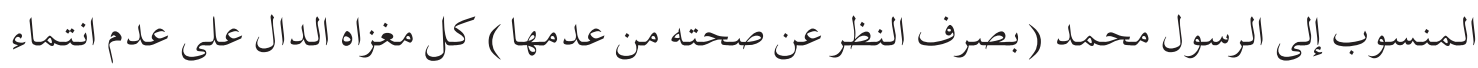

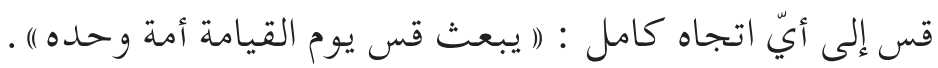

ع · ا ـ انظر أعلاه، الفقرة المتعلقة بالمكان، نجران.

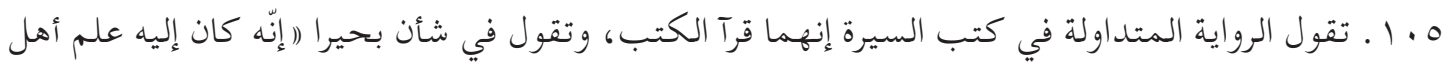

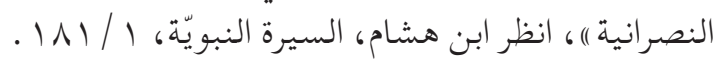


أما في المستوي العملي فلا شك أن هذا التيار ـ الذي لا يمكٍٍن رؤيته من خلال حالة واحلدة ـ

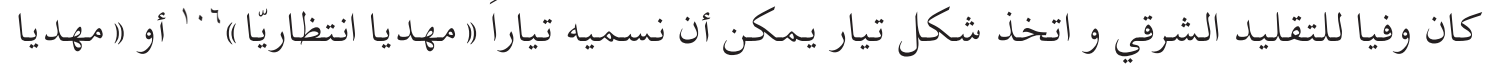

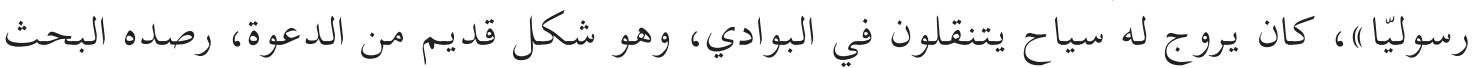

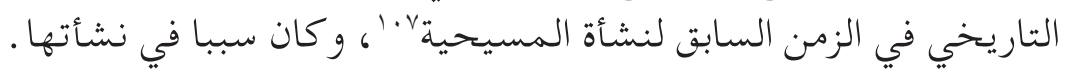

ـ الدعوة : إذا اعتبرنا الإِطار الديني أو العقدي إطارا ثقافيا للتعبير، يحق التساؤل عن العوامل

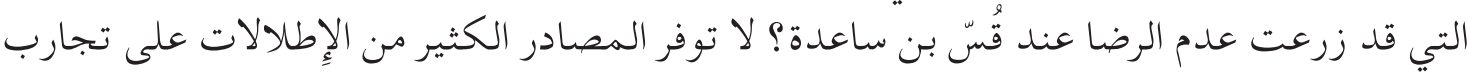

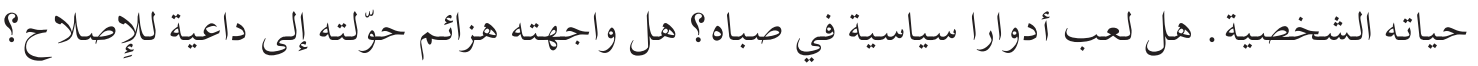

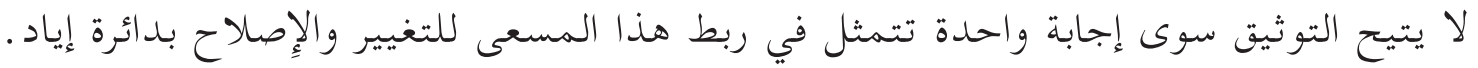

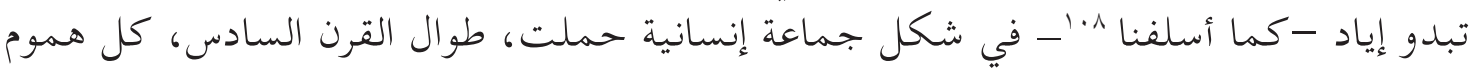

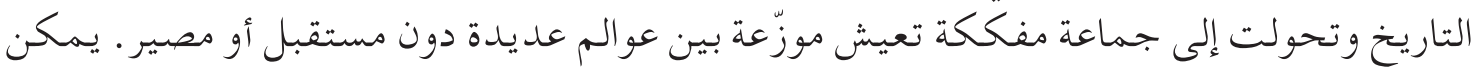

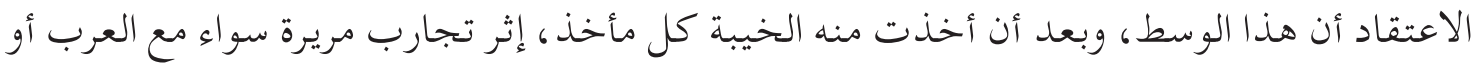

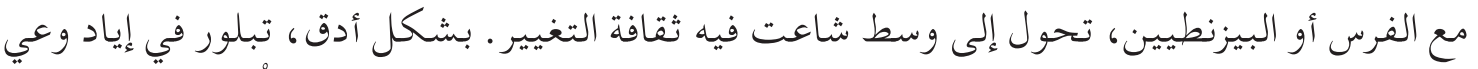

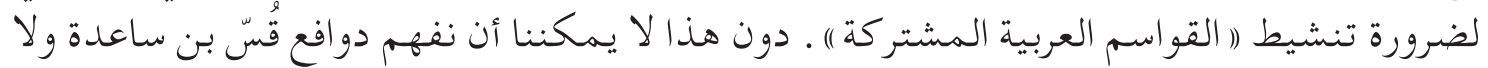

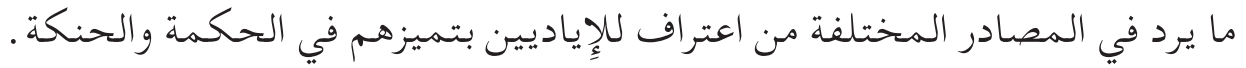

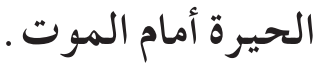

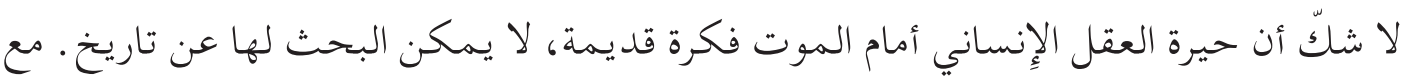

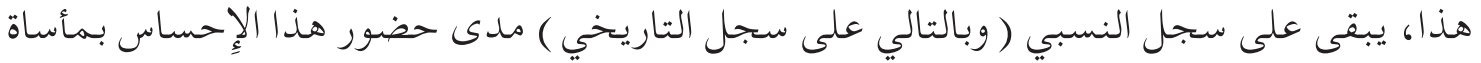

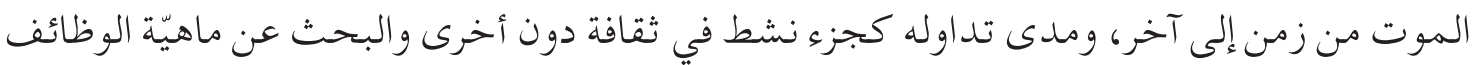

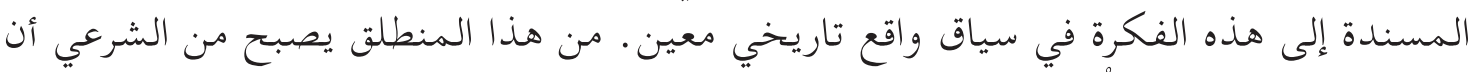

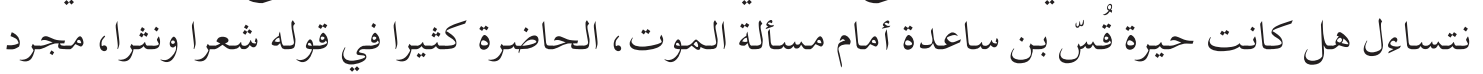

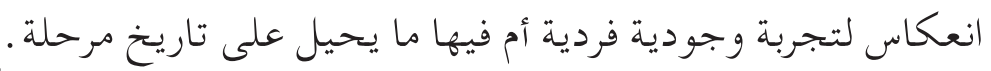

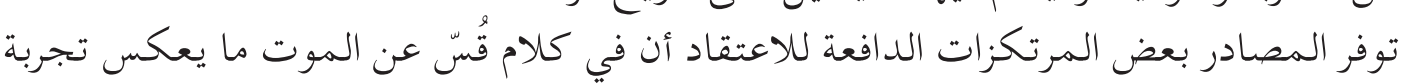

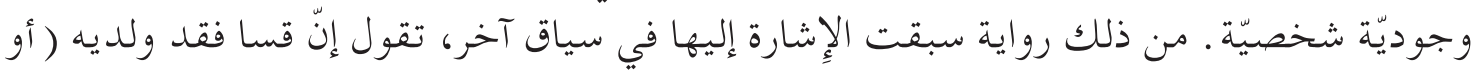

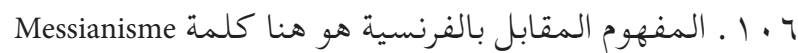

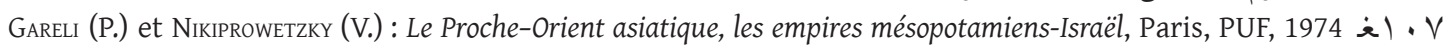
« L'histoire du Judaïsme palestinien à partir du II siècle avant notre ère atteste l'attente fiévreuse ou l'on était du Prophète comparable à Moïse grâce auquel toutes les difficultés concernant l'application légitime des dispositions de la Tora seraient aplanies. A cette attente le christianisme lui-même est redevable à quelque degré de son existence. انظر كذلك: . Albert SouEd, La révolution des messies: Judaïsme, christianisme et islam, Paris : L’Harmattan, 2000. p. 75

$$
\text { ^ • ا . انظر أعلاه، الفقرة المتعلقة بالوسط الاجتماعي. }
$$




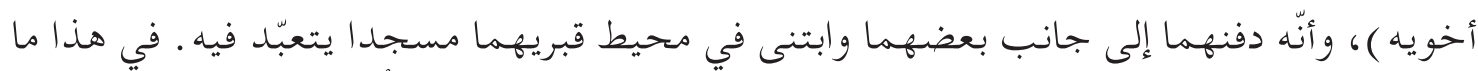

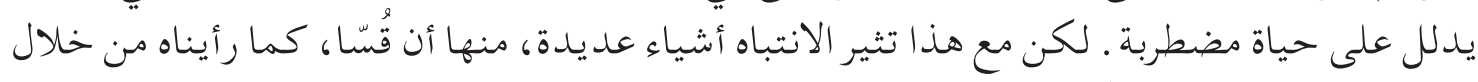

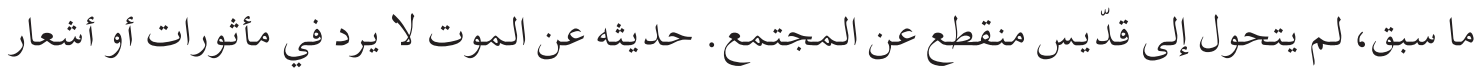

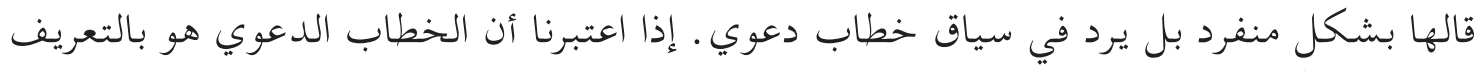

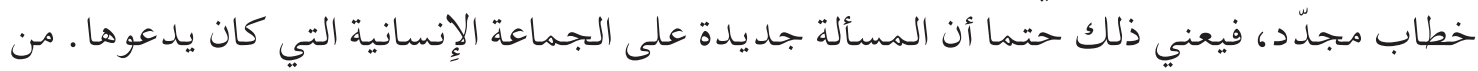

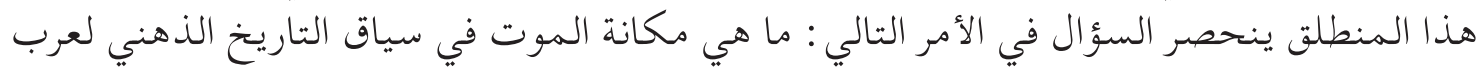

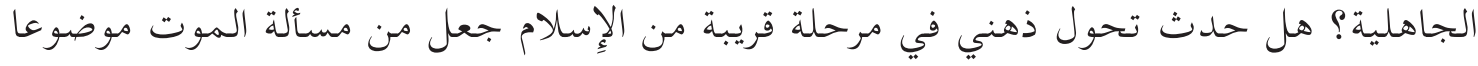

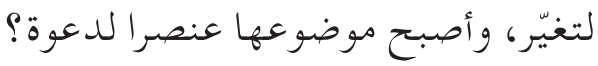

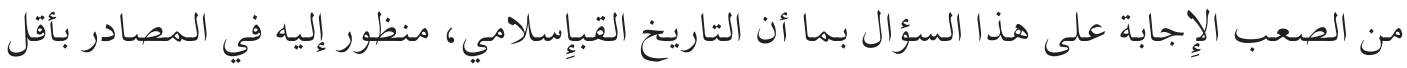

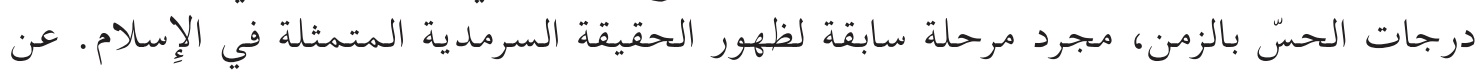

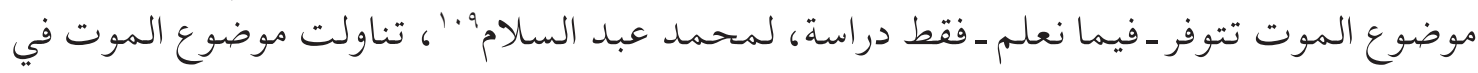

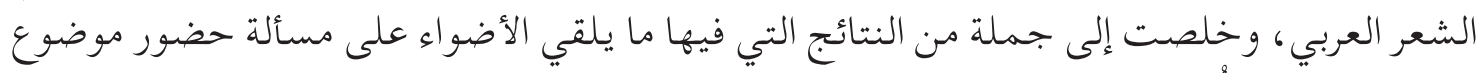

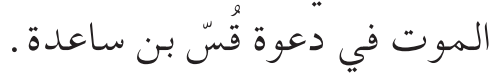

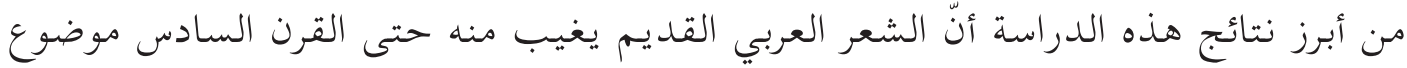

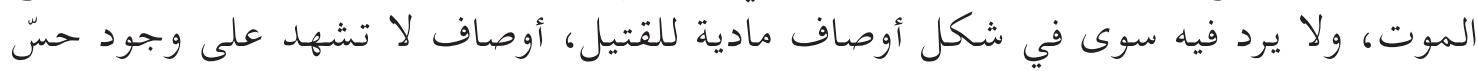

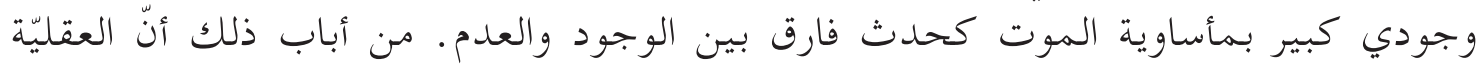

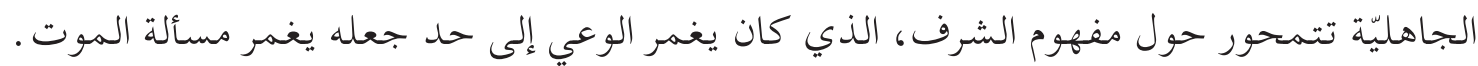

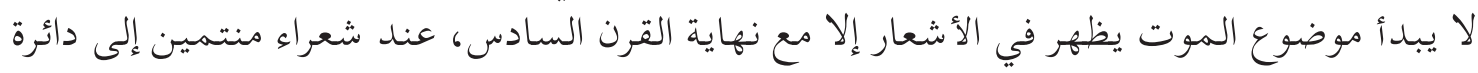

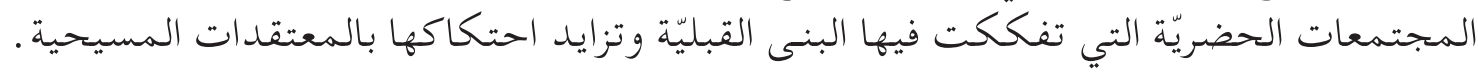

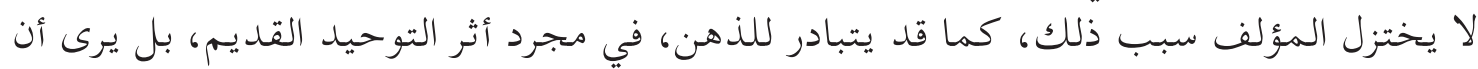

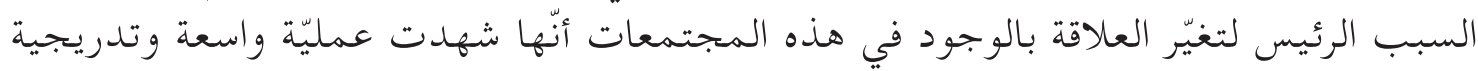

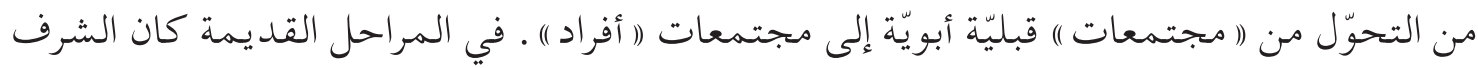

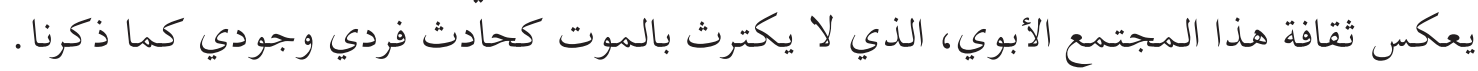

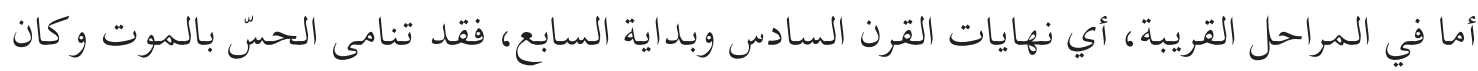

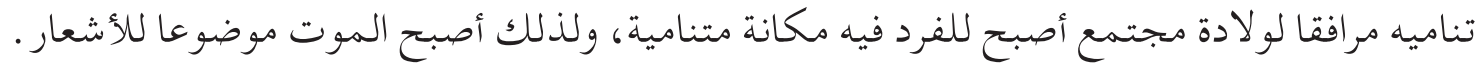

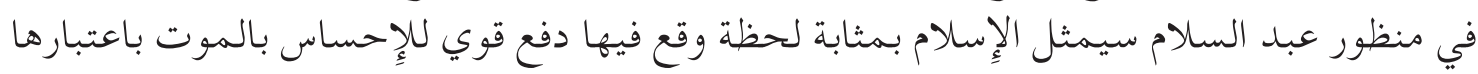

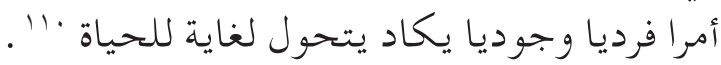

Abdesselem, M., Le thème de la mort dans la poésie arabe, Tunis, Faculté des Lettres, 1977, p. 356 خ l • 9 • 11. المبدو لنا استنتاجات محمد عبد السلام، المتعلقة بالشعر، متوافقة مع بعض الأخبار التي تعكسها

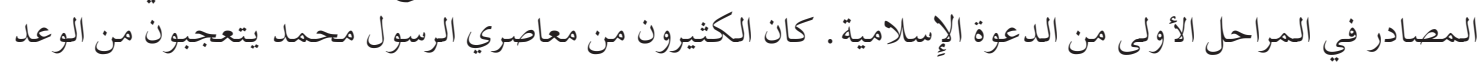


لا شك أن في نتائج دراسة عبد السلام ما يمثل إطارا تاريخيا مساعدا على فهم الدعوة التي

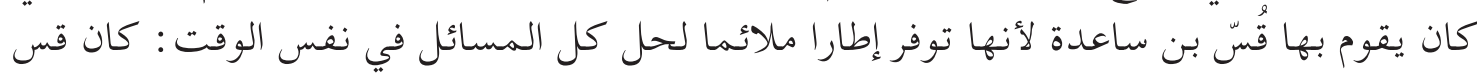

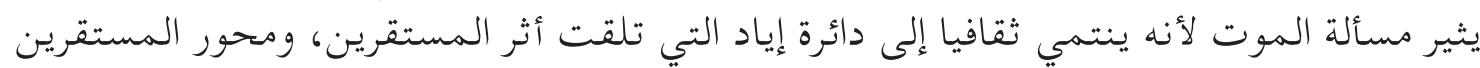

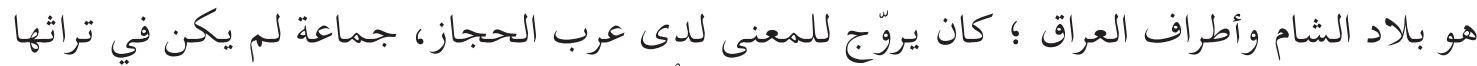

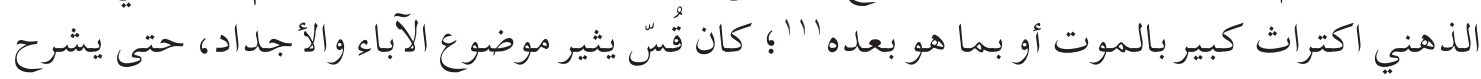

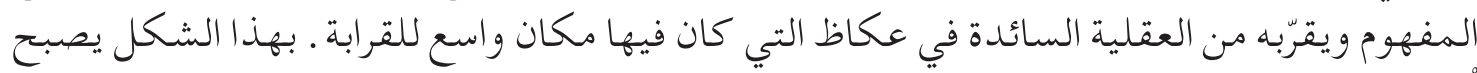

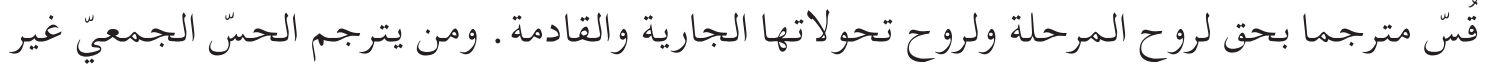

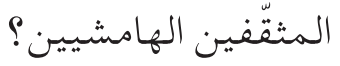

\section{ـ تأمل في الكينونة وفي الخلق و الطبيعة :}

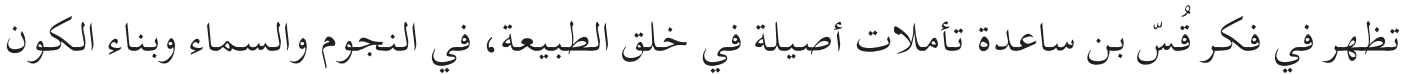

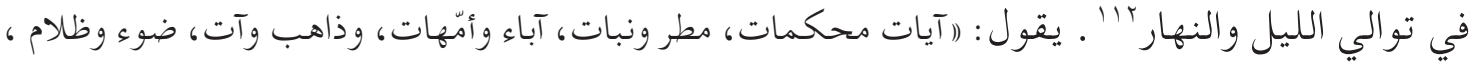

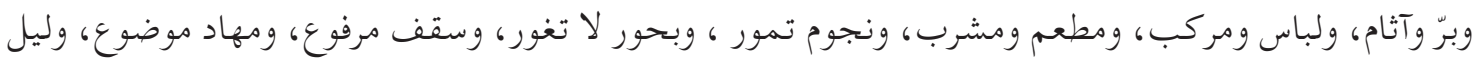

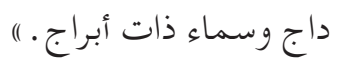

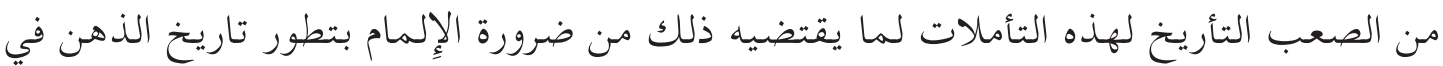

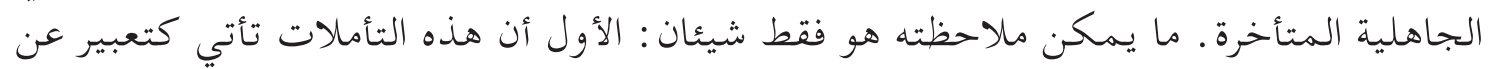

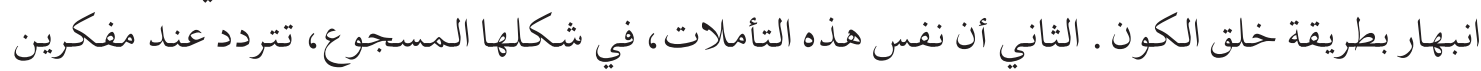

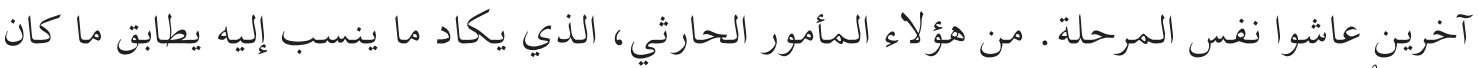

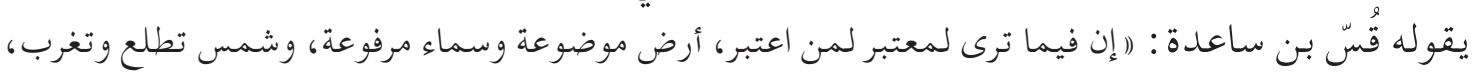

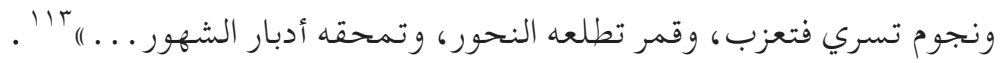

بالبعث بعد الموت . يحق التساؤل إن كانت الإقدام الكبير لرجال القبائل في عمليات الفتح في علاقة مع ثقافة

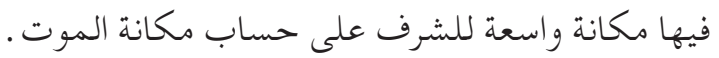

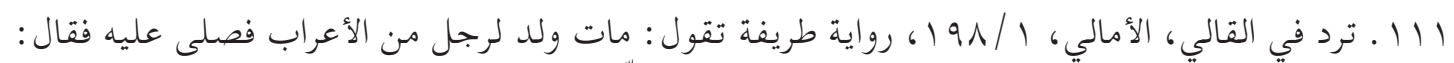

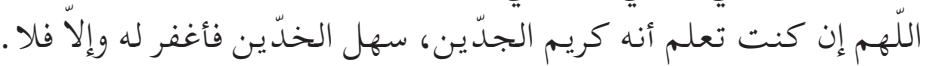

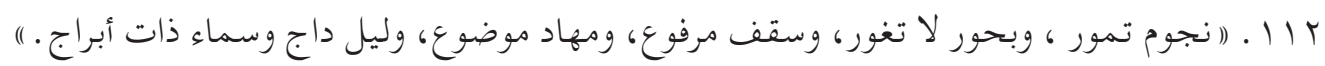

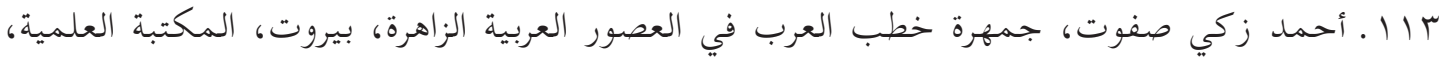


مستوى السّياسة و القانون :

ما هي اتجاهات التغيير عند قُسٌّ تتوفر في دائرة الرواية بعض النبذ الدالة على هذه الاتجاهات ،

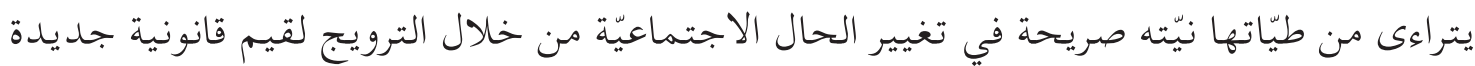

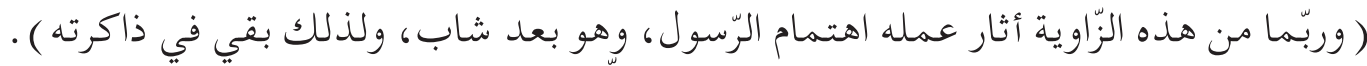

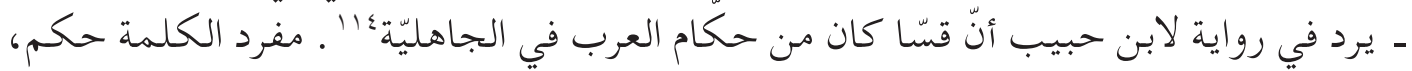

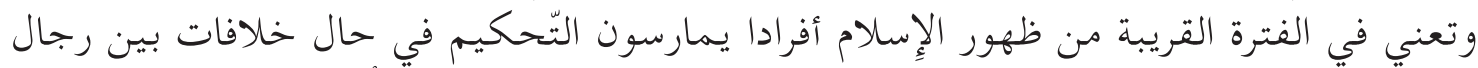

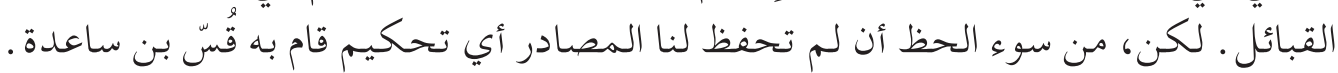

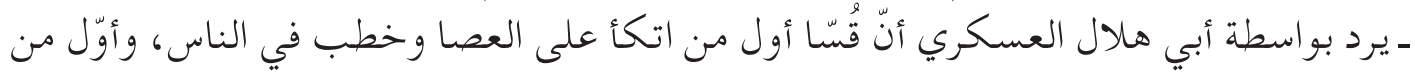

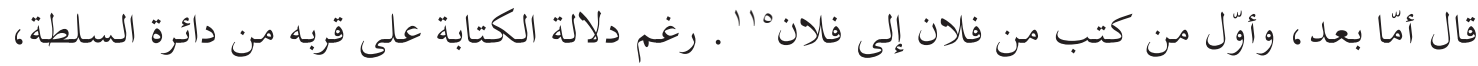

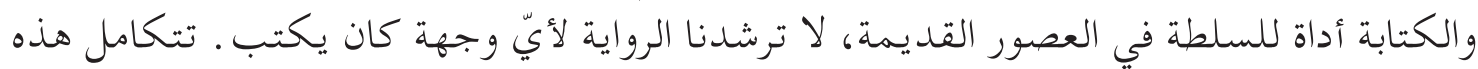

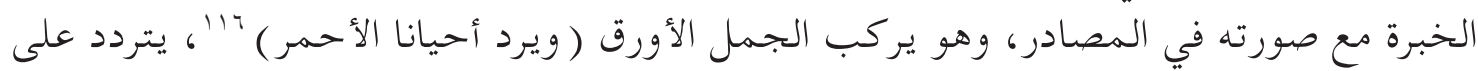

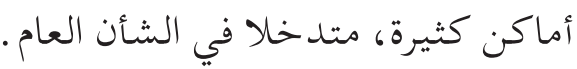

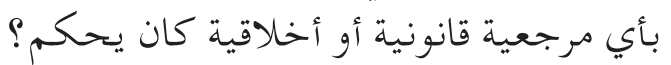

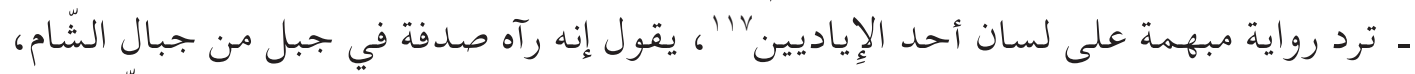

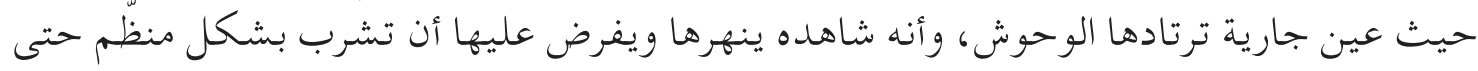

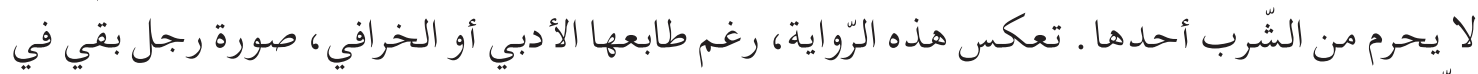

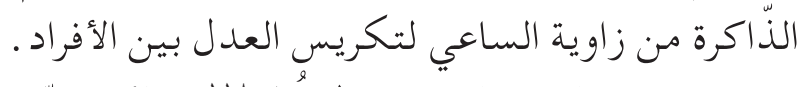

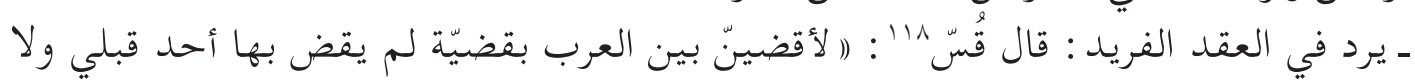

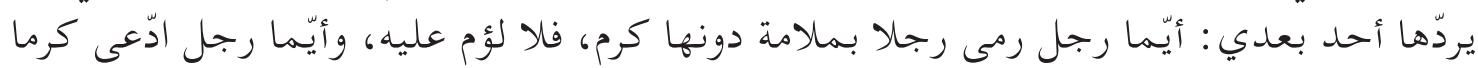

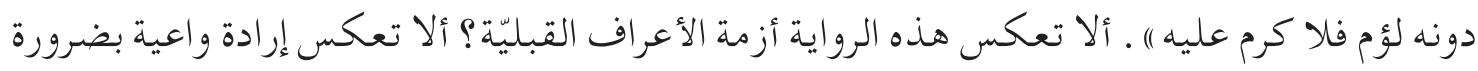
تعديل القيم التقليدية في اتجاه أكثر واقعية؟

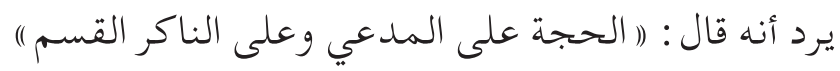

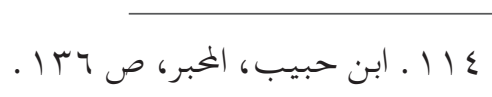

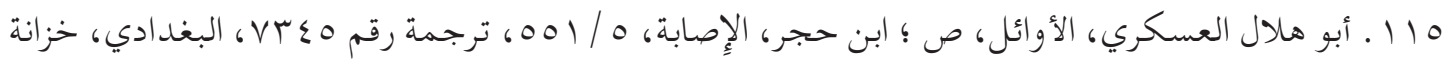

$$
\begin{aligned}
& \text { الأدب، ب / • 9، ومصادر أخرى كثيرة. } \\
& 11 \text { ا } 11 \text { ـ انظر الفقرات الأولى. }
\end{aligned}
$$

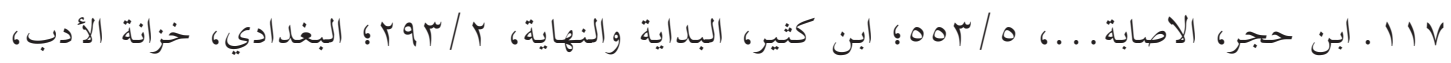
ا

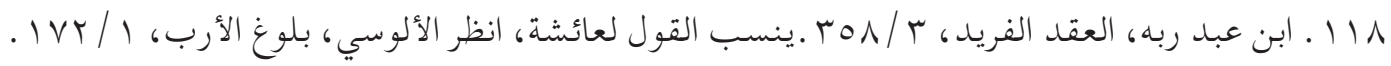




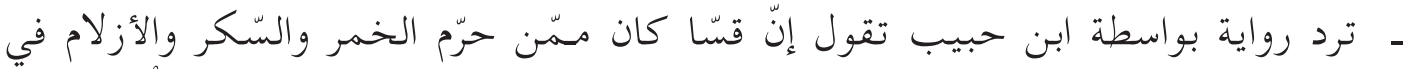

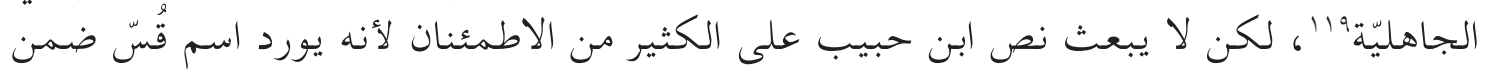

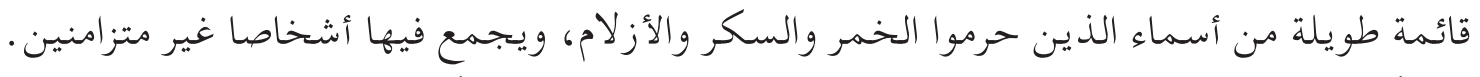

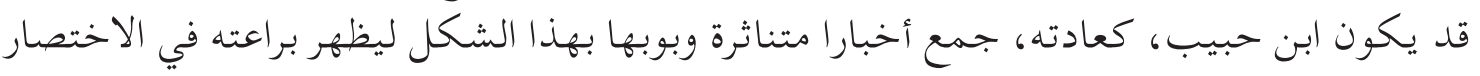

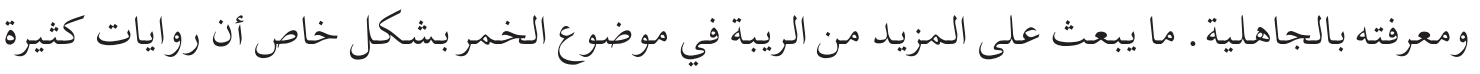

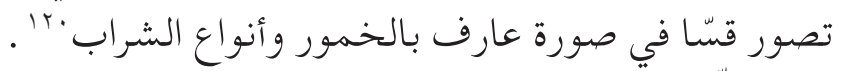

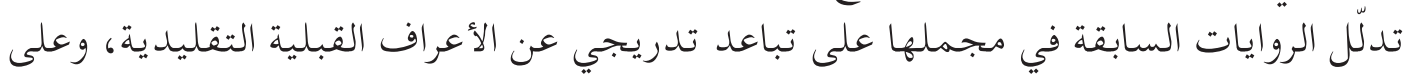

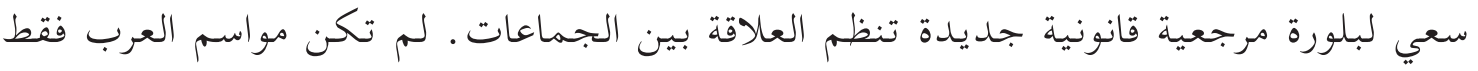

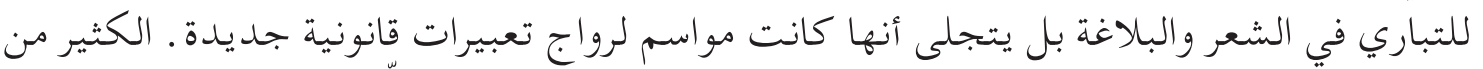

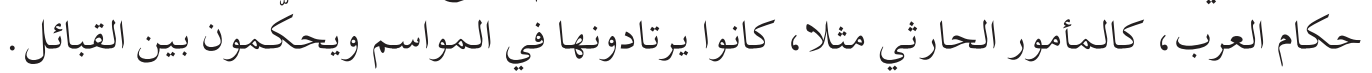

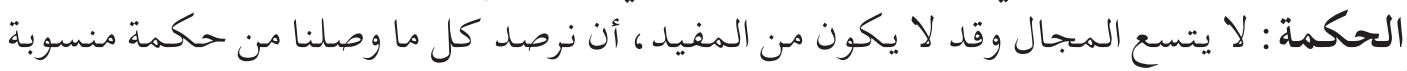

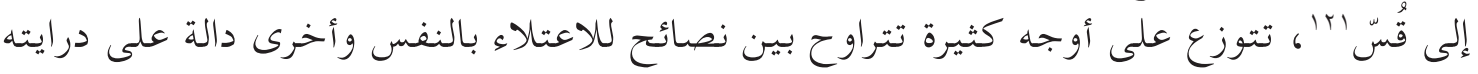

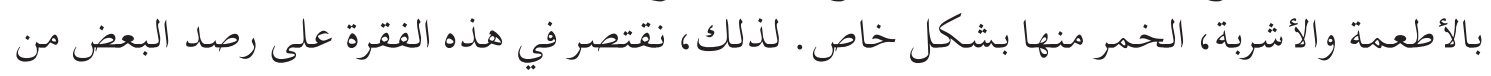

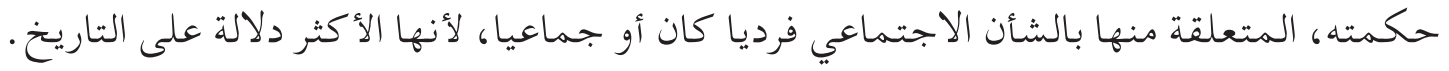

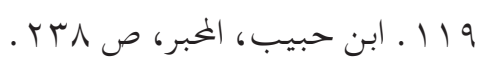

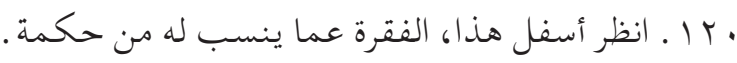

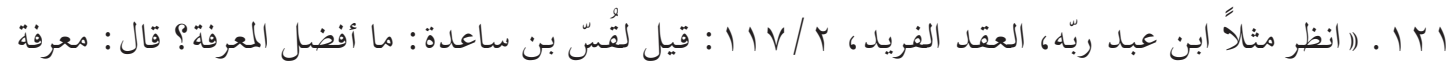

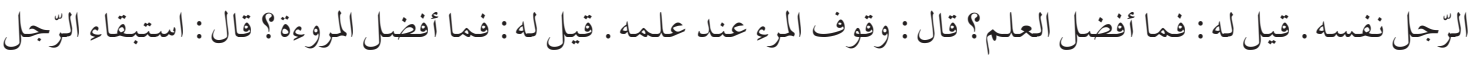

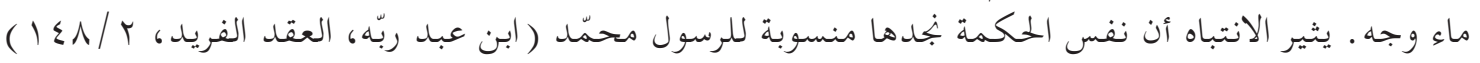

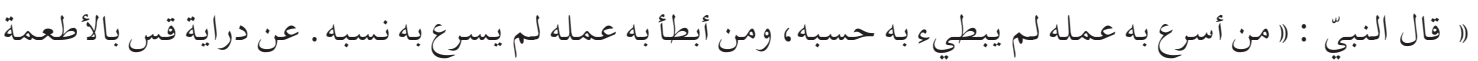

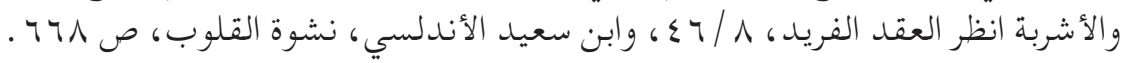

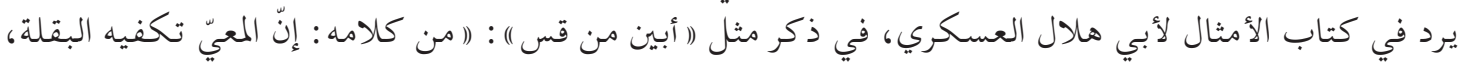

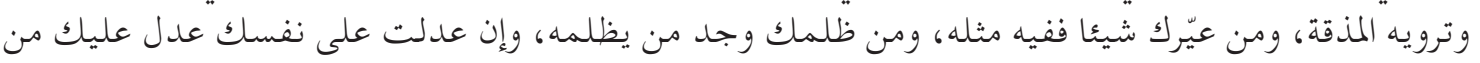

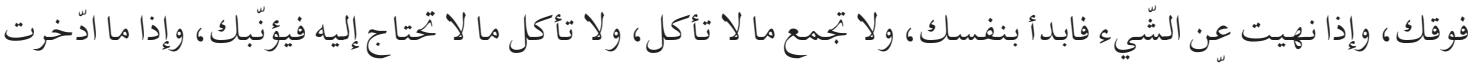

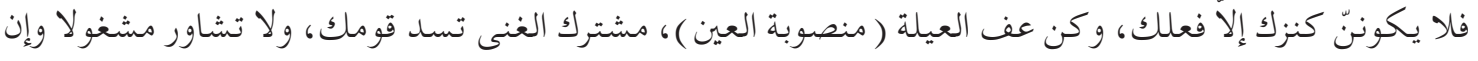

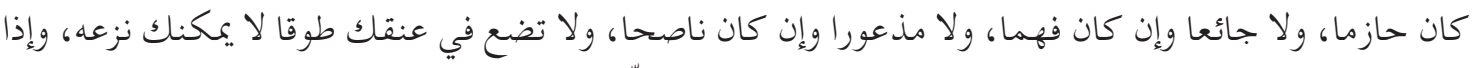

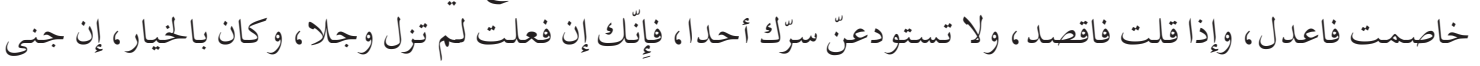

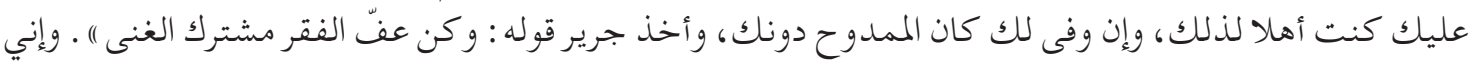

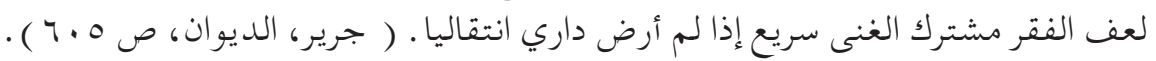




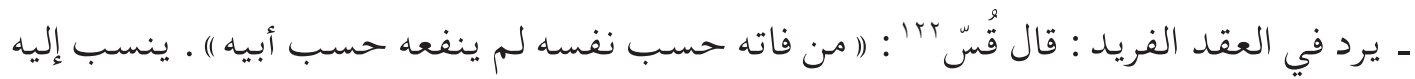

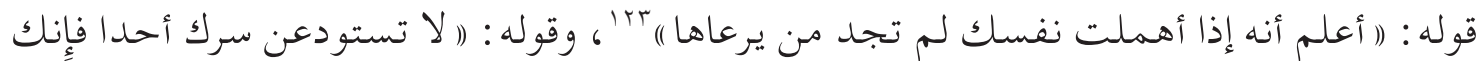

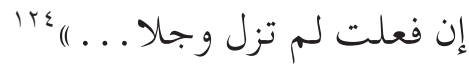

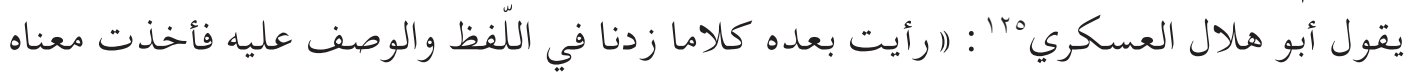

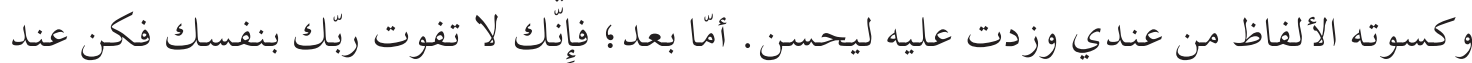

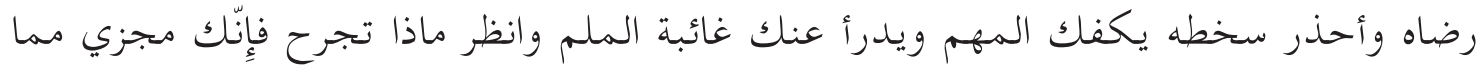

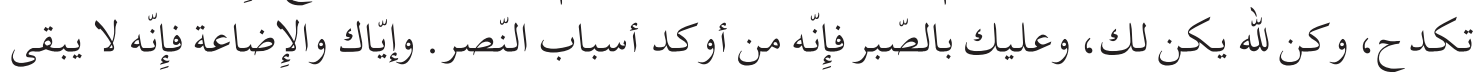

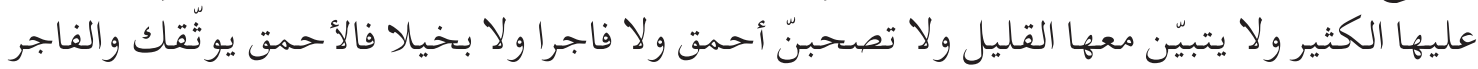

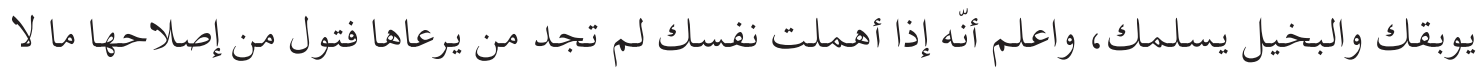

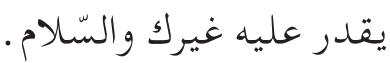

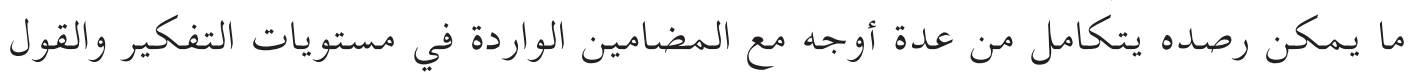

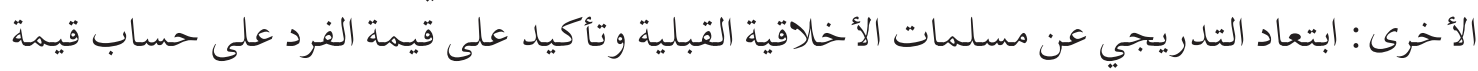

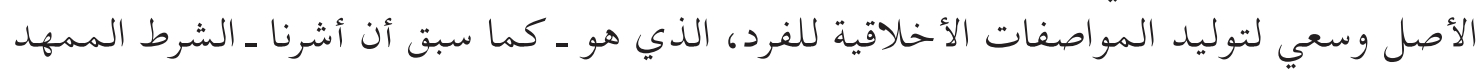

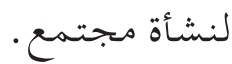

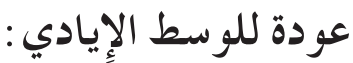

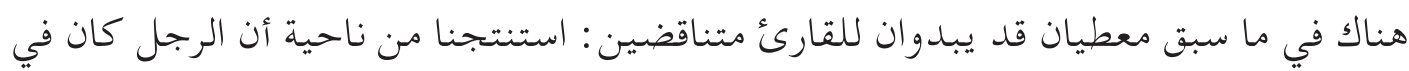

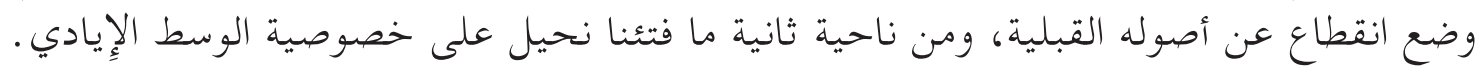

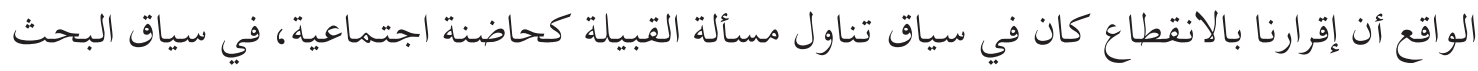

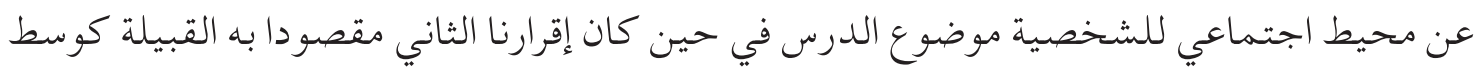

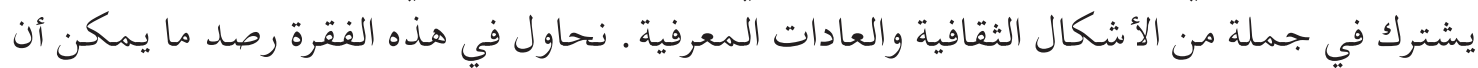

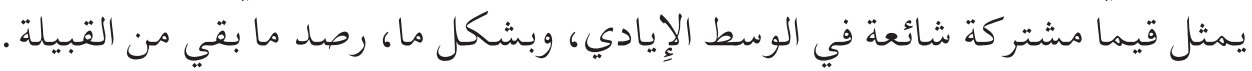

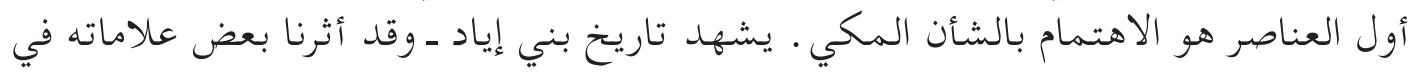

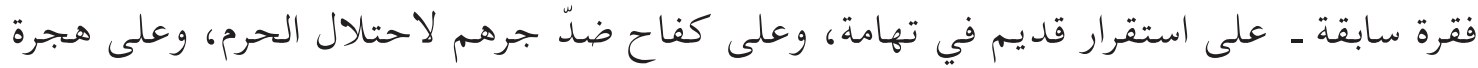

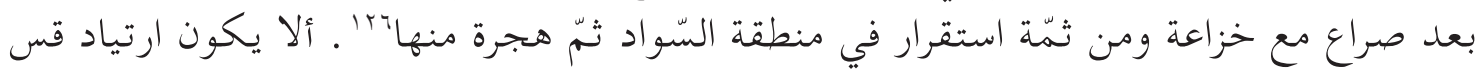

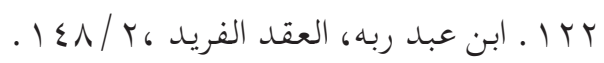

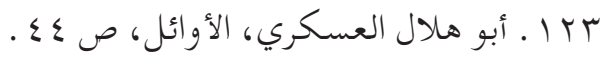

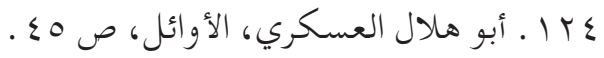

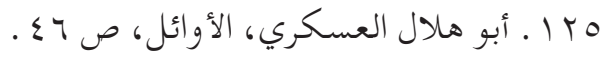

$$
\begin{aligned}
& \text { ؟ب ا ـ انظر أعلاه، الفقرة الثانية. }
\end{aligned}
$$




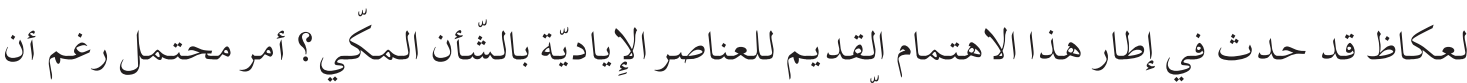

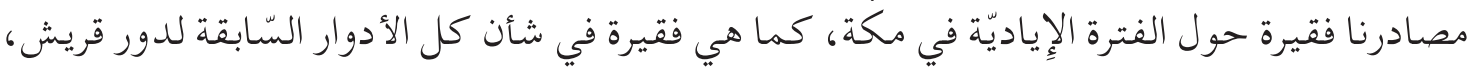

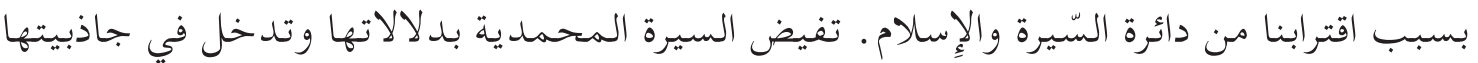

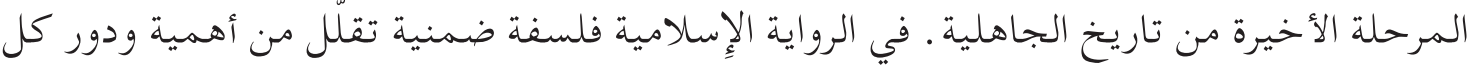

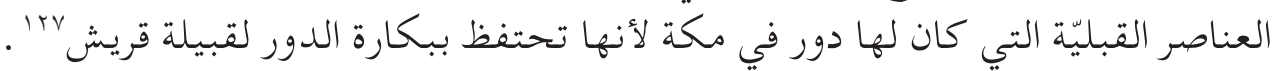

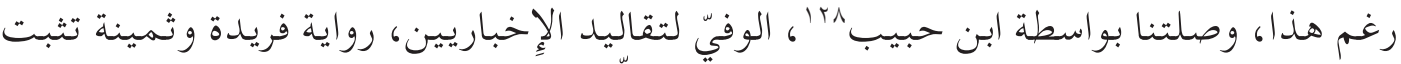

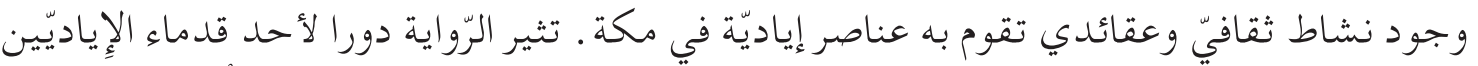

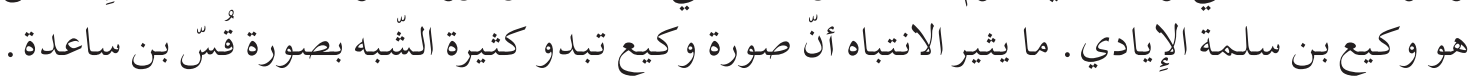

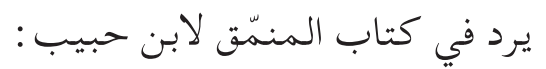

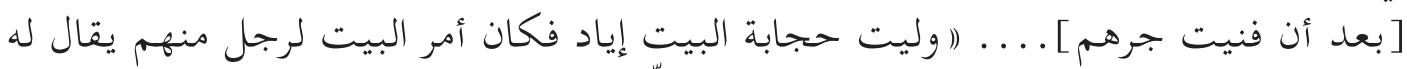

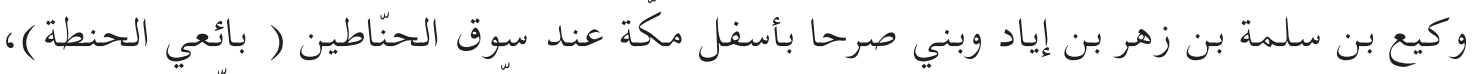

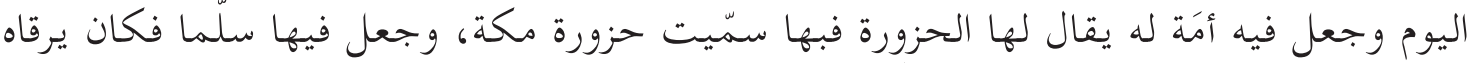

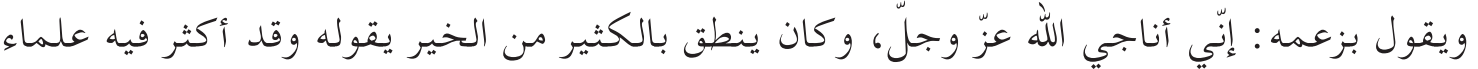

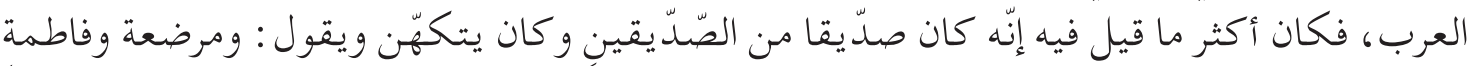

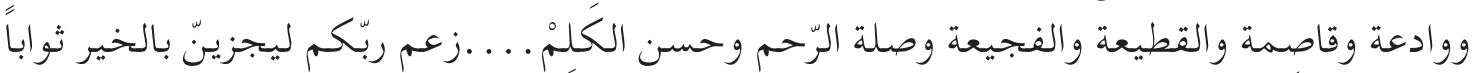

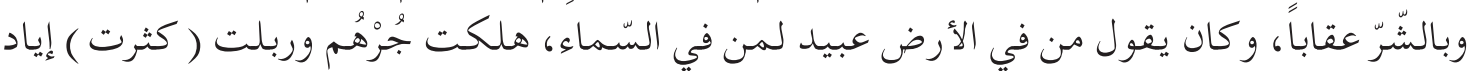

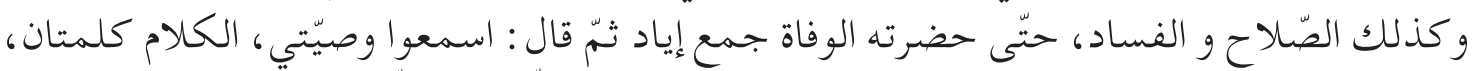

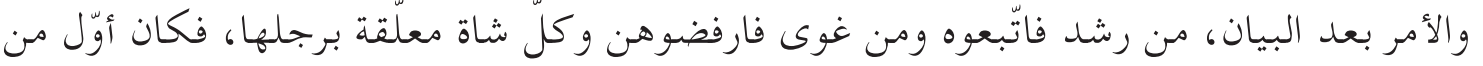

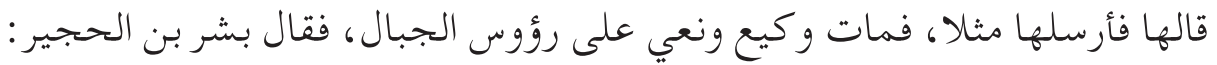

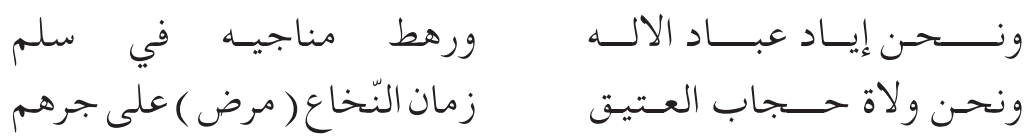

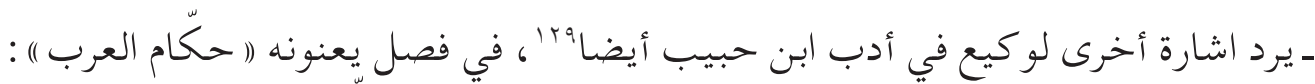

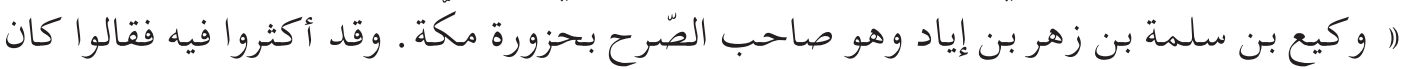

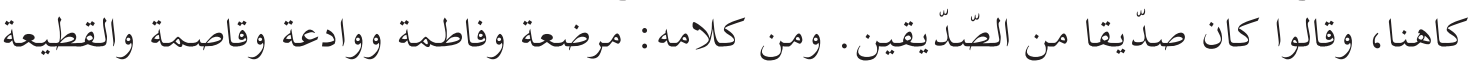

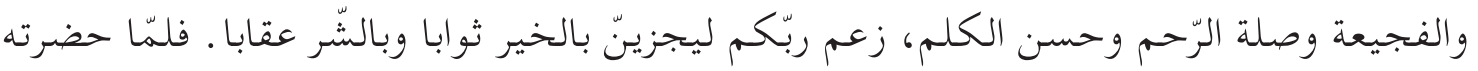

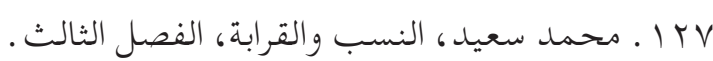

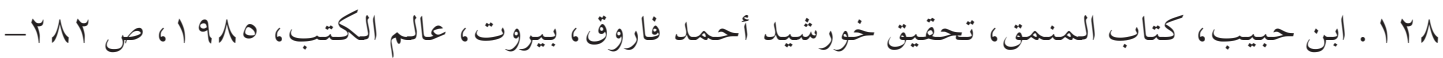




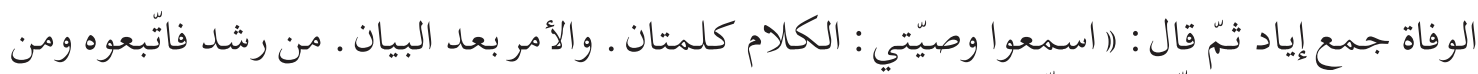

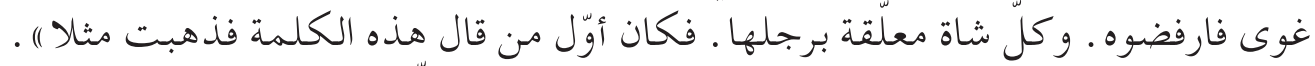

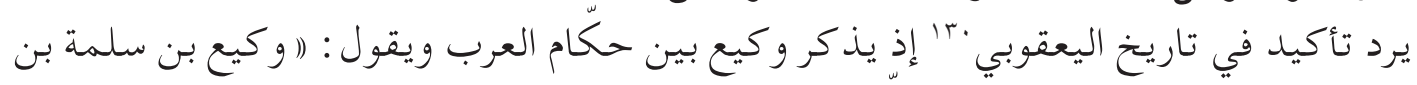

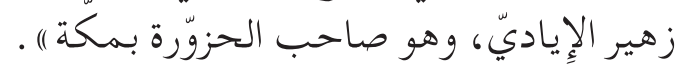

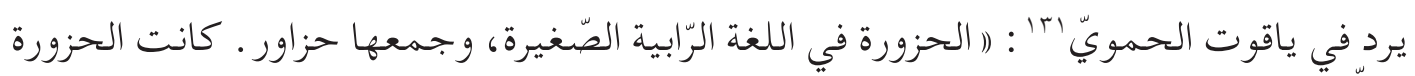

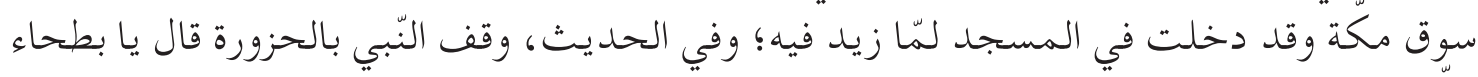

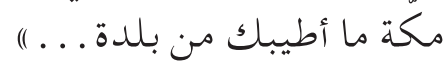

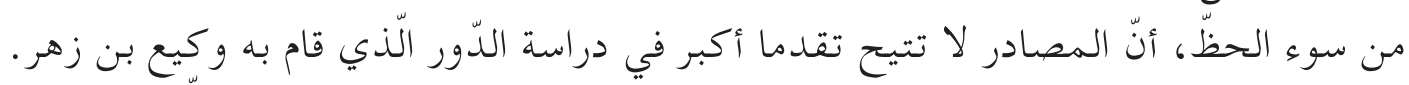

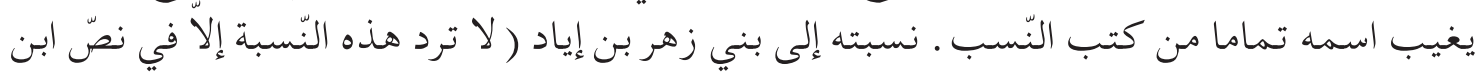

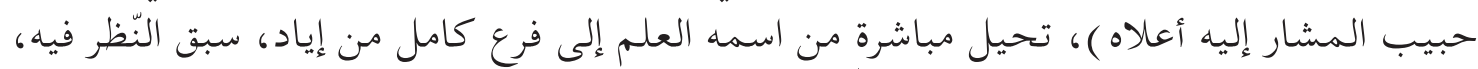

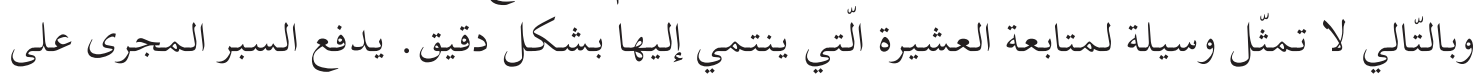

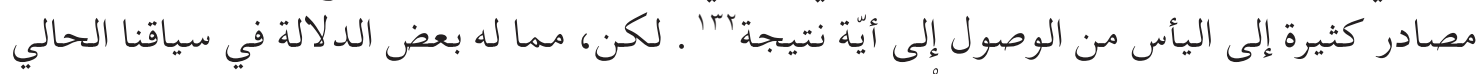

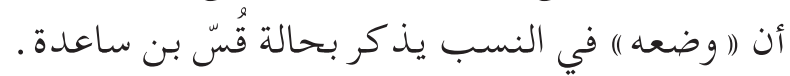

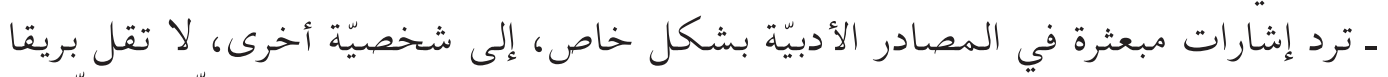

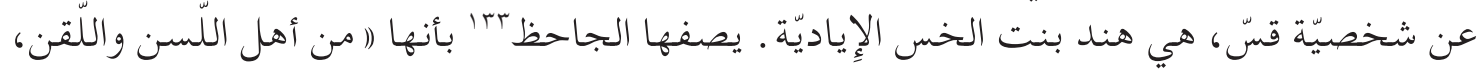

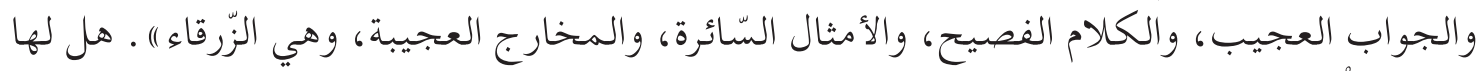

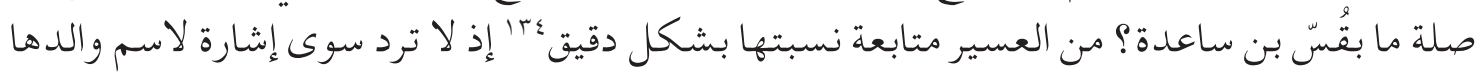

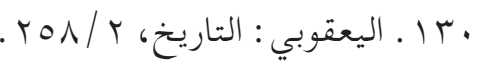

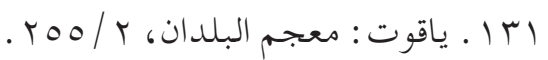

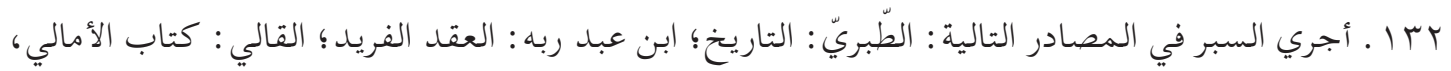

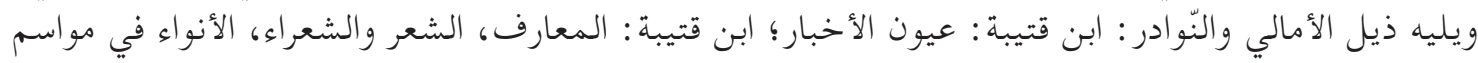

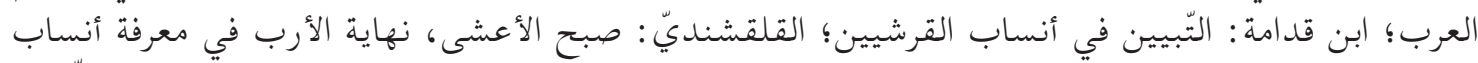

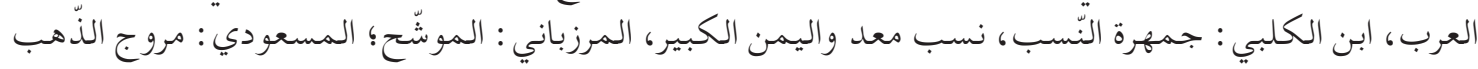

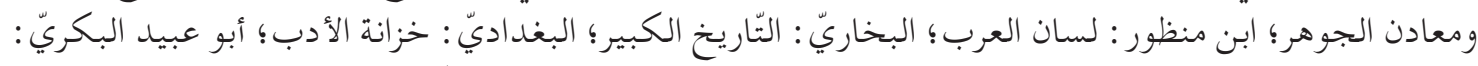

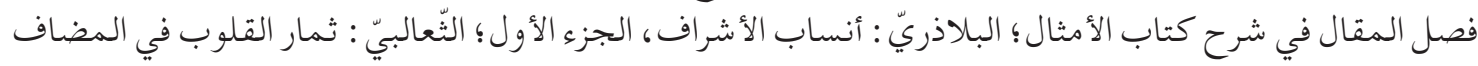

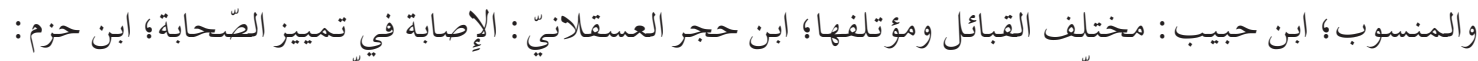

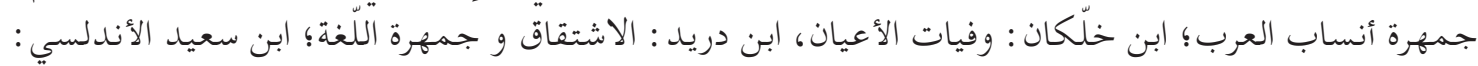

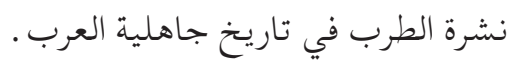

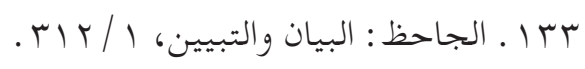

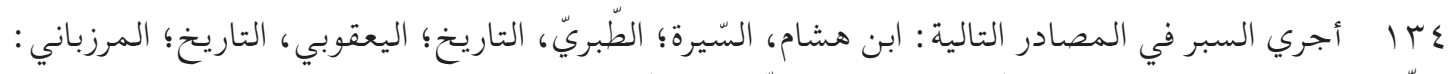

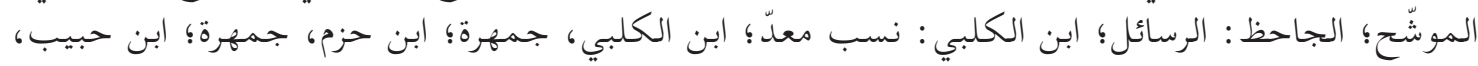




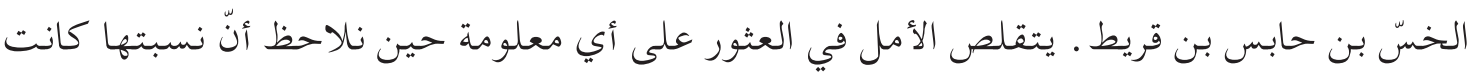

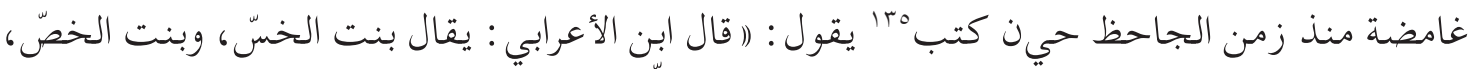

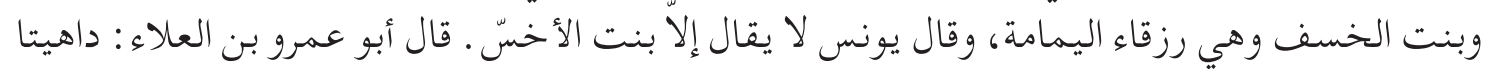

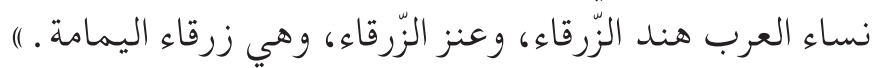

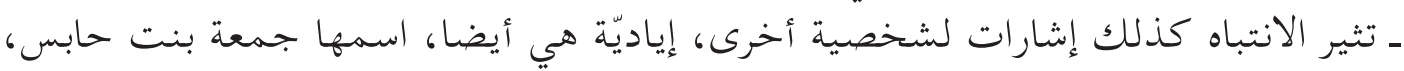

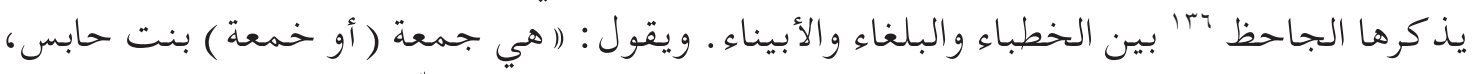

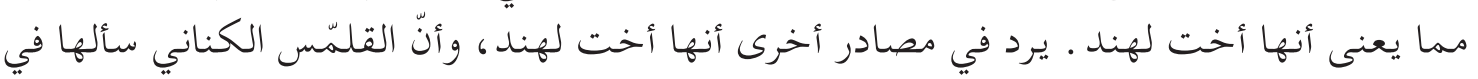

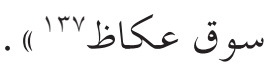

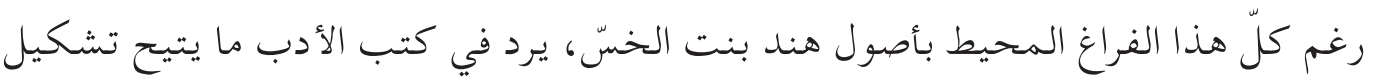

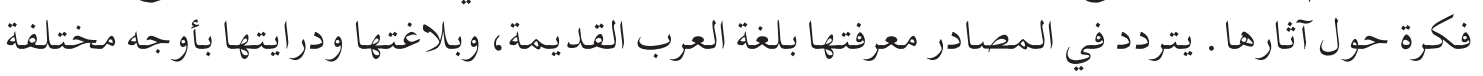

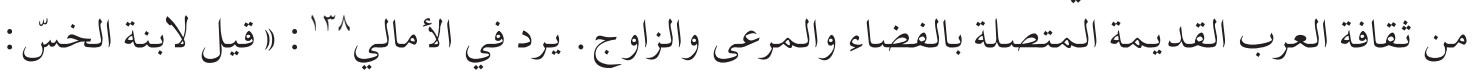

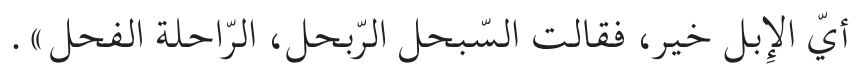

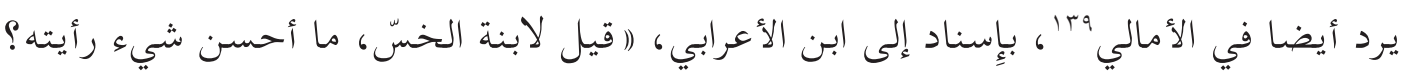
قالت : غادية، في إثر سارية، في نبخاء قاوية ـ ل) .

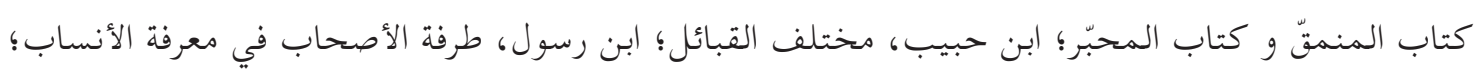

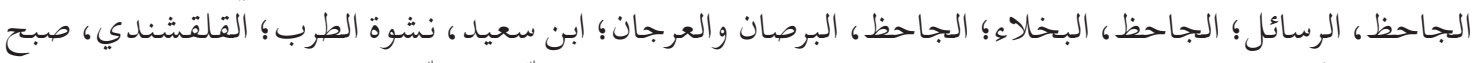

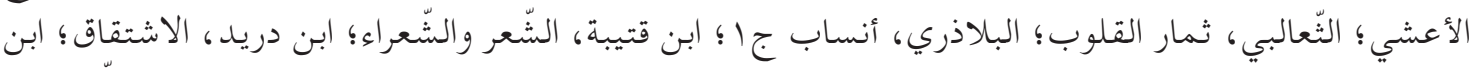

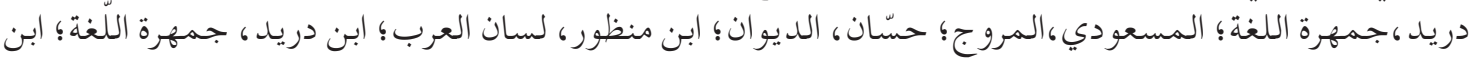

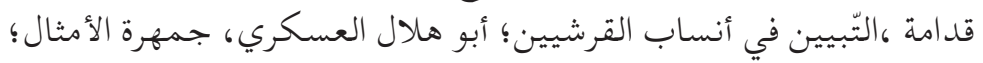

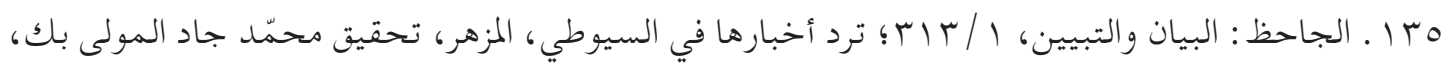

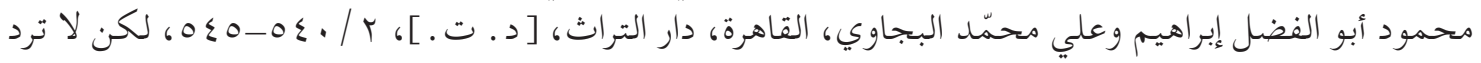
تسميتها إلا مقتضبة .

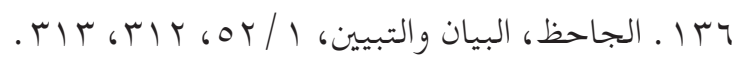

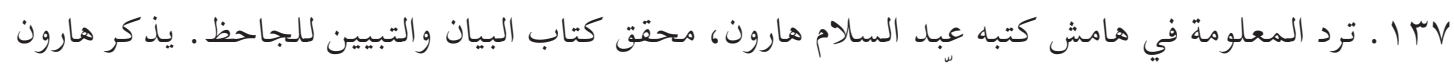

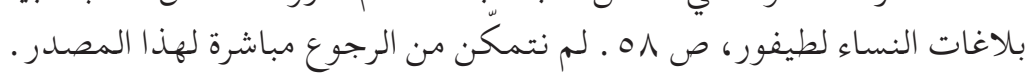

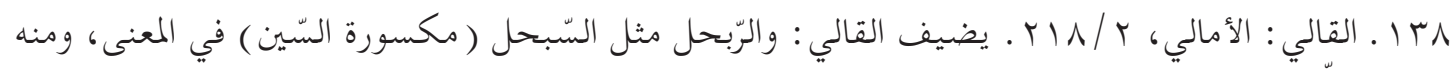

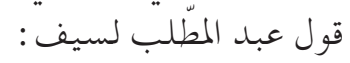

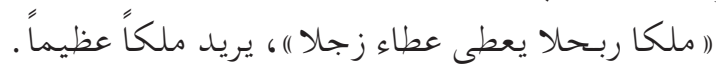

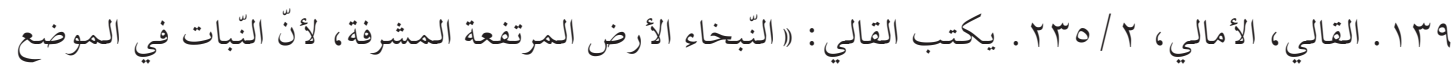

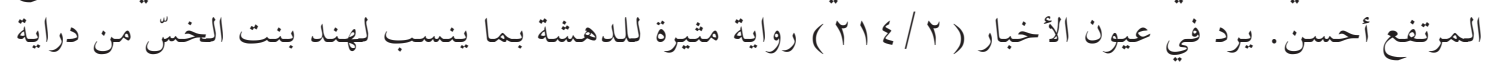
باللغة العربية واشتقاقاتها ). 
- يرد في الأمالي ‘ُّ، باسناد إلى بهدل الزّبيريّ: (أتى رجل ابنة الخسّ يستشيرها في امرأة

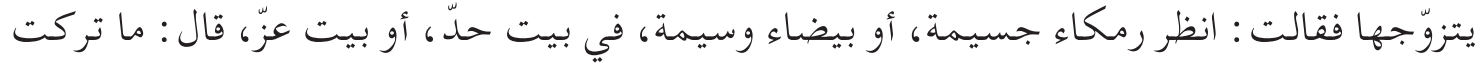

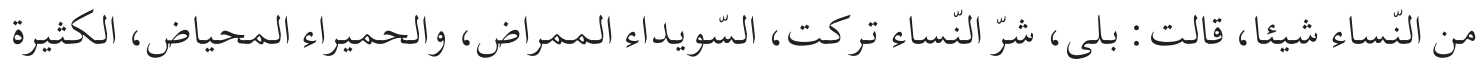

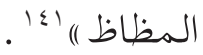

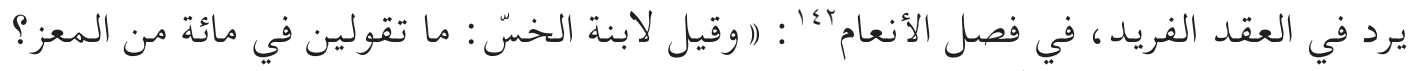

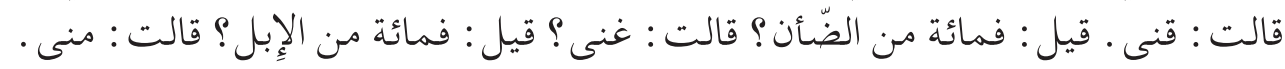

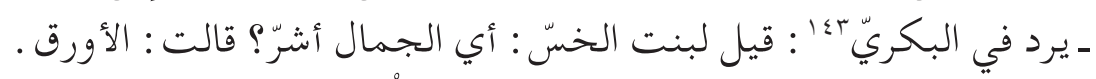

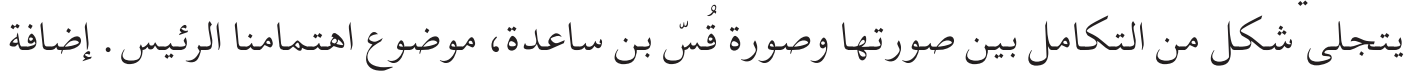

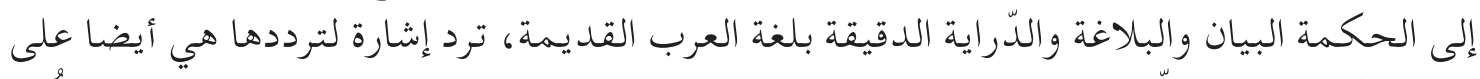

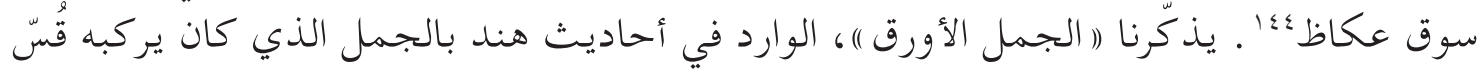

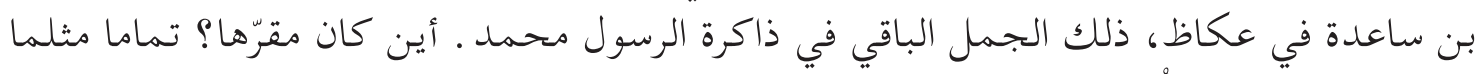

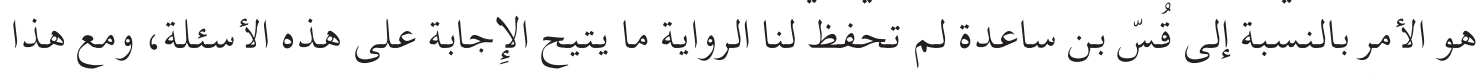

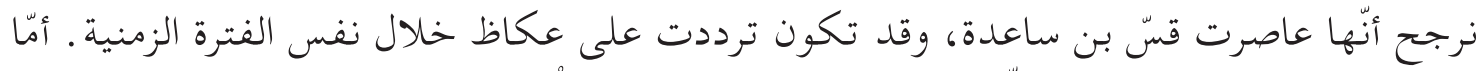

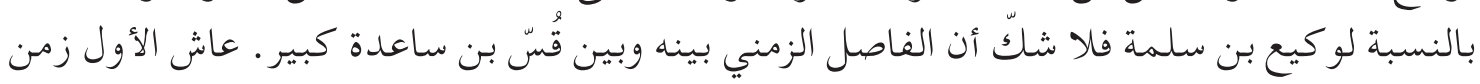

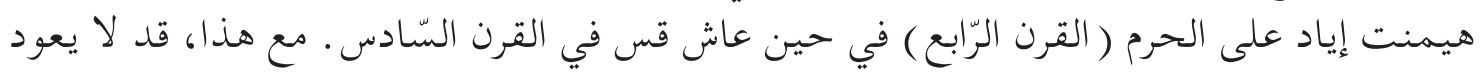

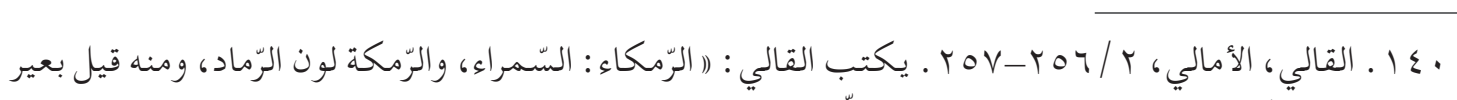

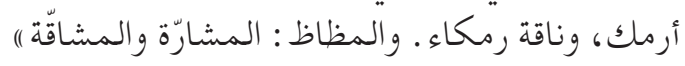

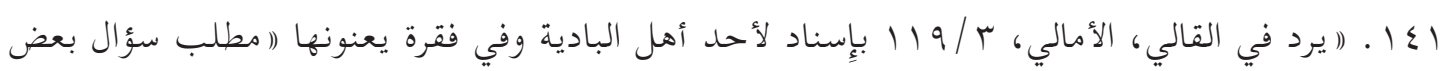

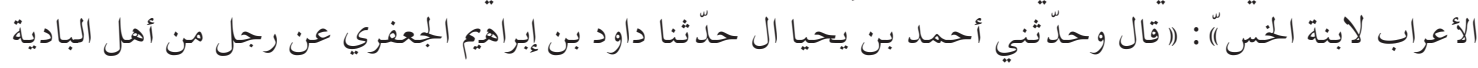

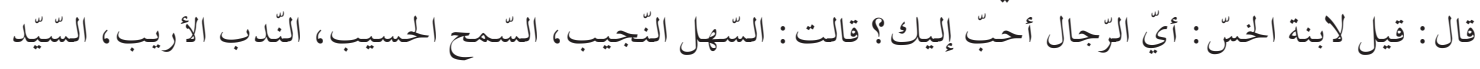

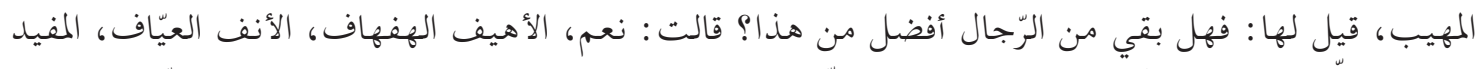

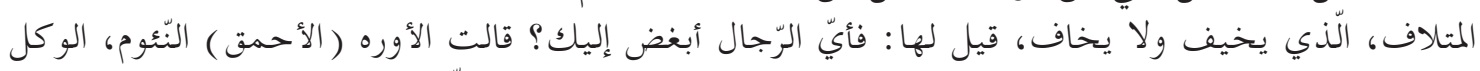

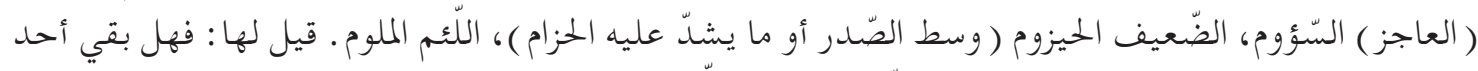

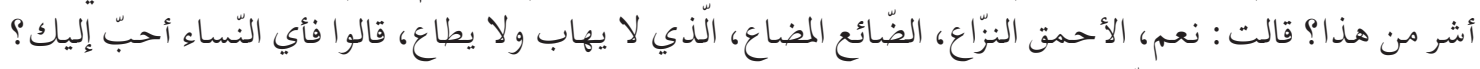

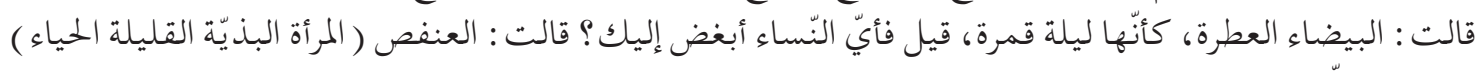

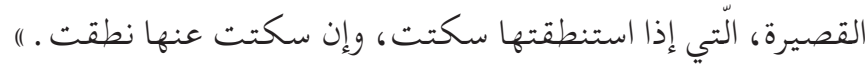

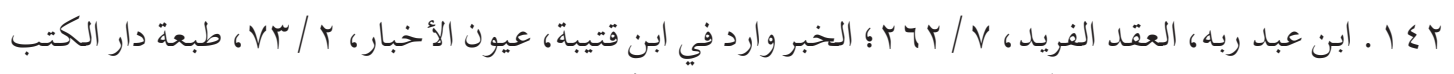

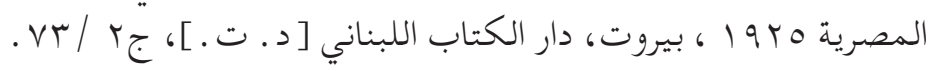

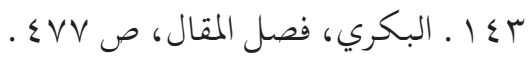

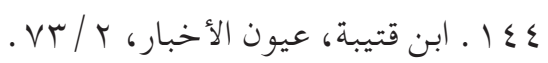




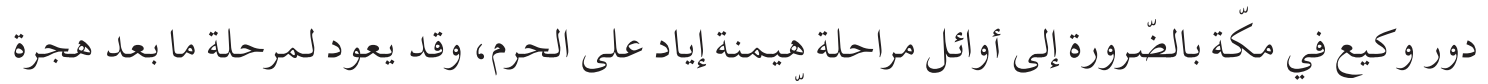

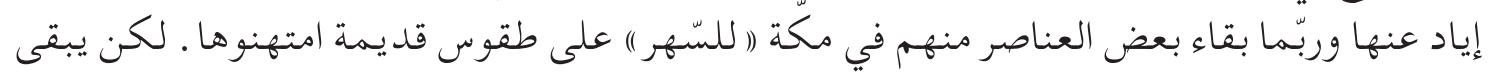

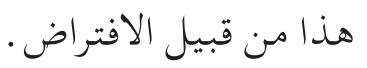

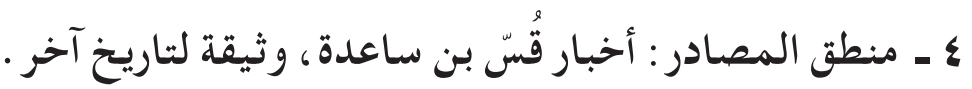

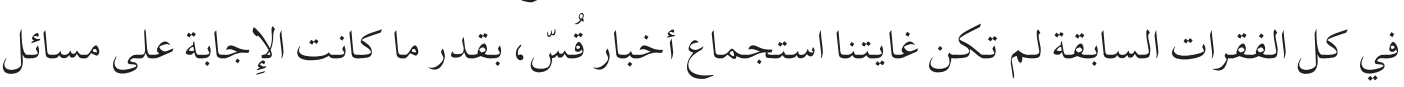

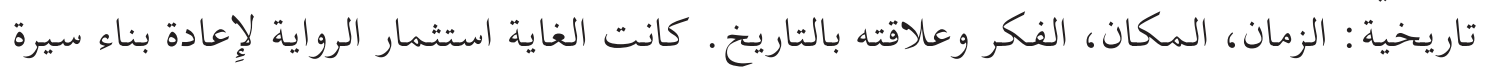

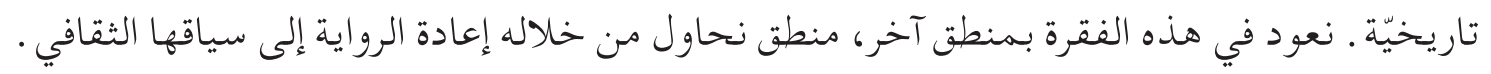

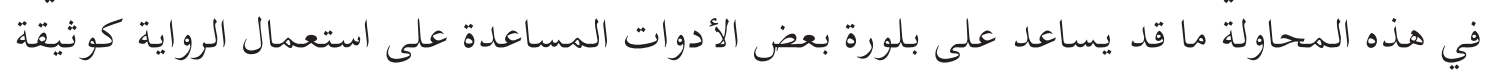

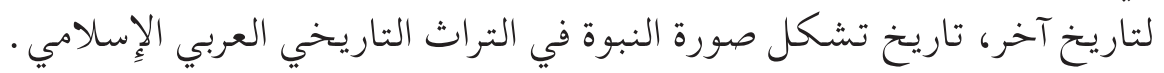

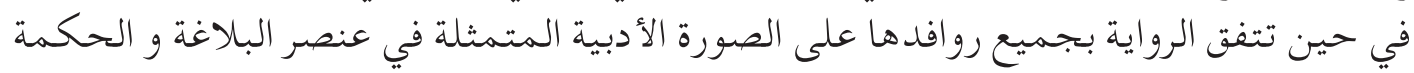

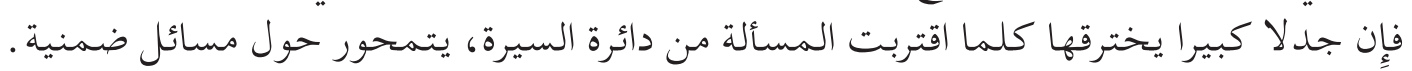

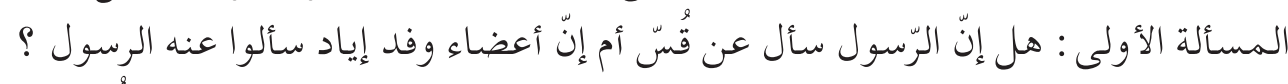

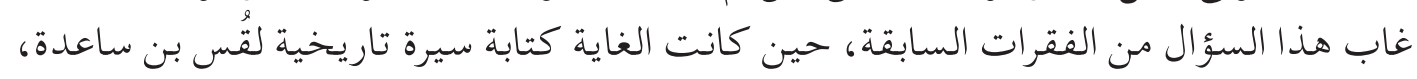

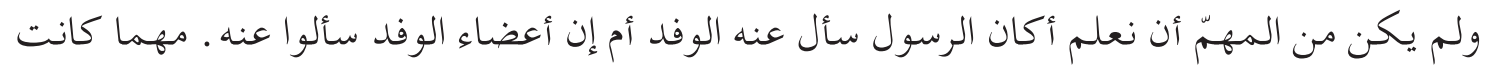

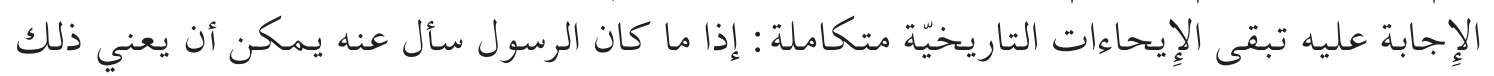

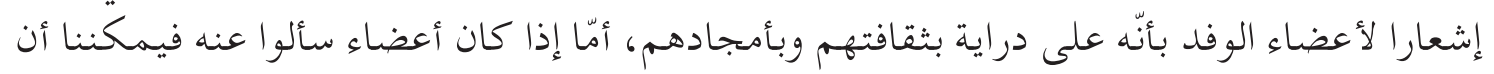

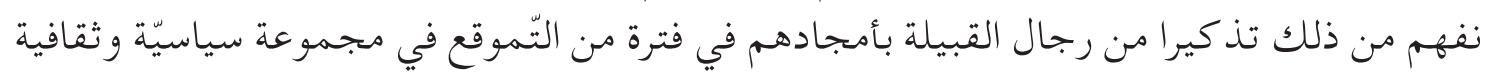

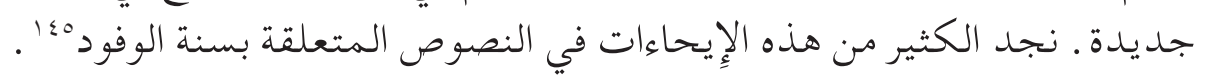

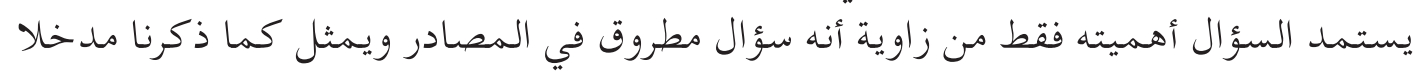

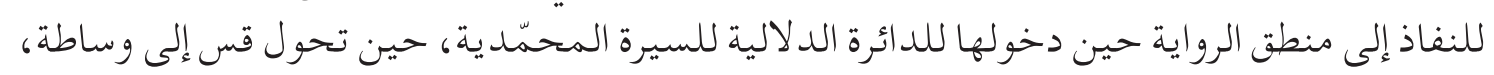

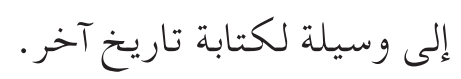
تتشكل في الرواية ثلاث إجابات مختلفة 


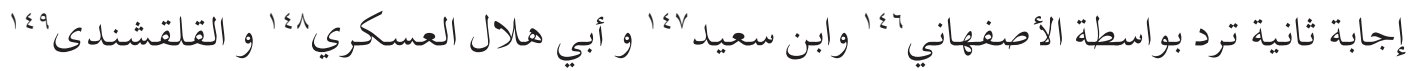

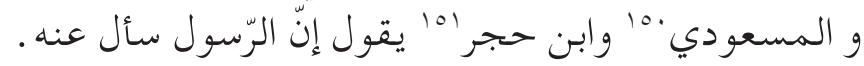

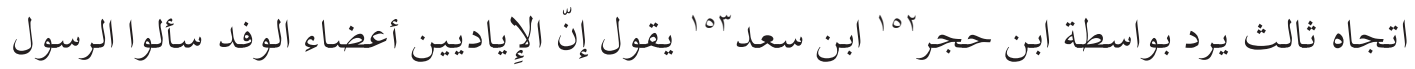
عنه، فقال لهم إنه يعرفه ويذكر كلامه .

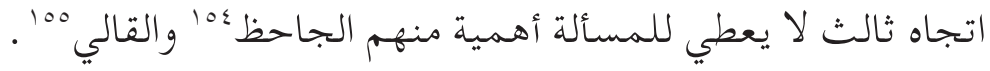

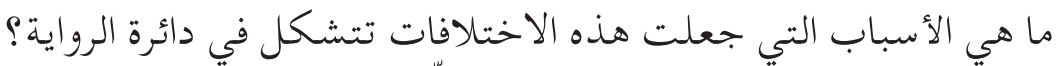

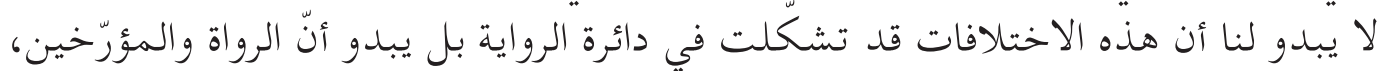

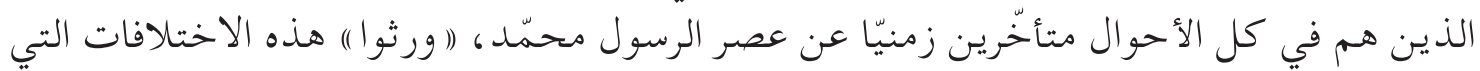

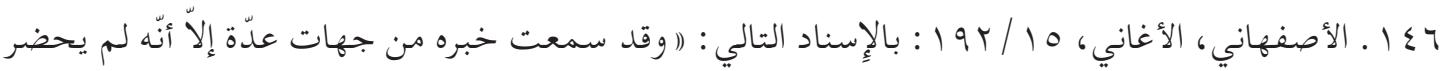

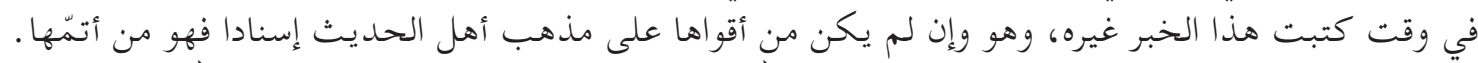

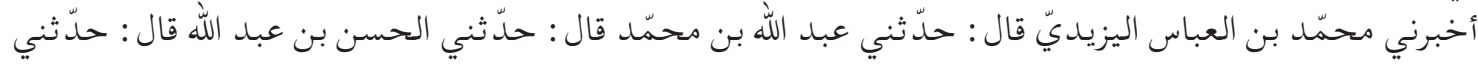

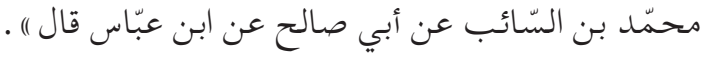
1 \&V

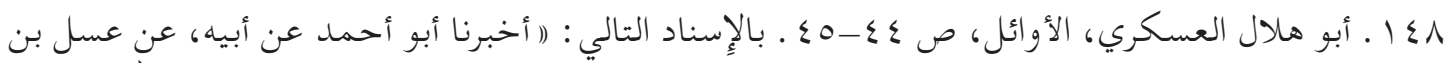

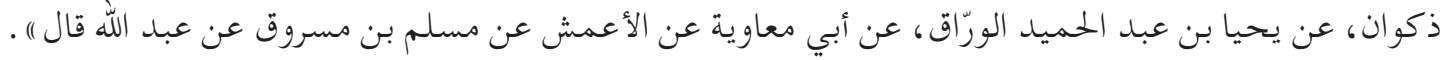

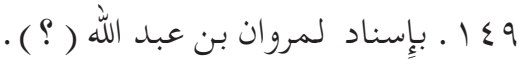

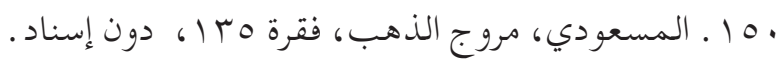

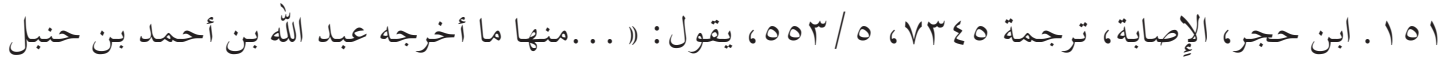

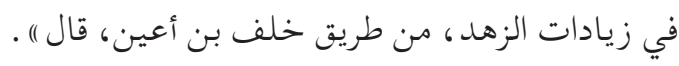

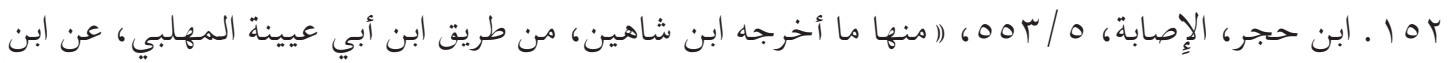

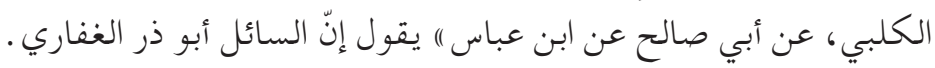

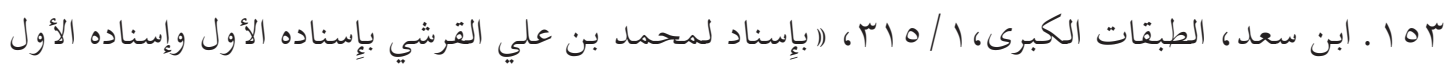

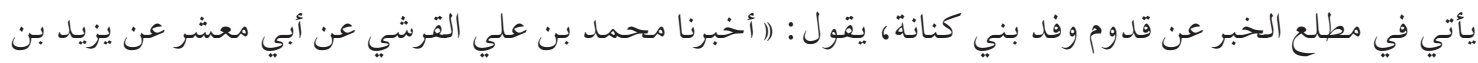

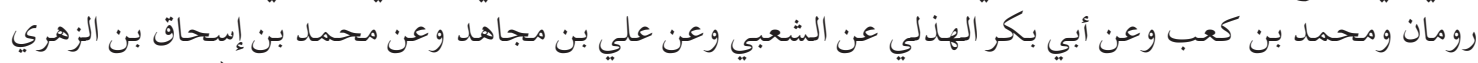

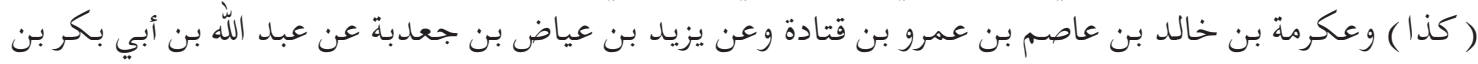

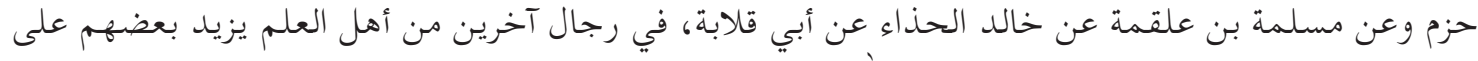

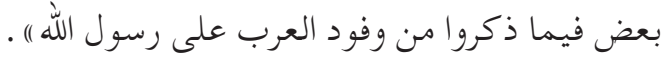

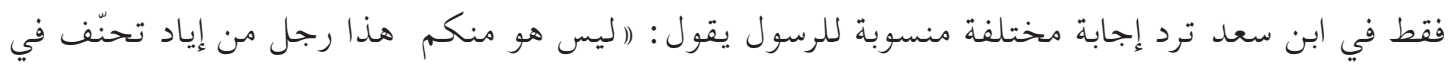

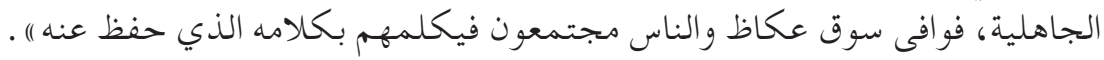

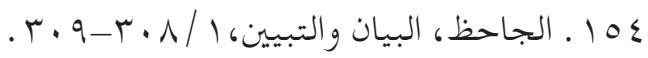
100 100 


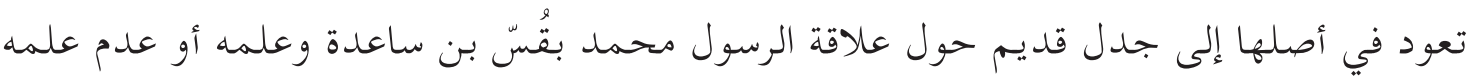

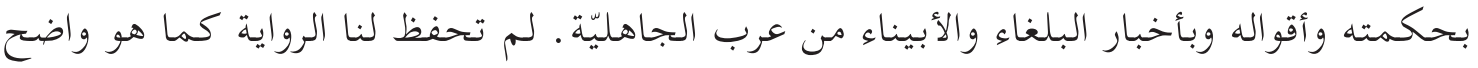

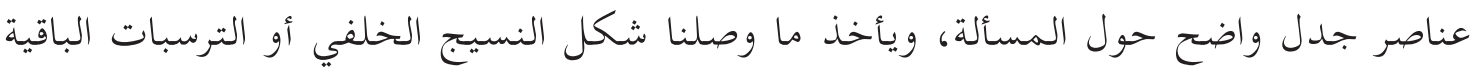

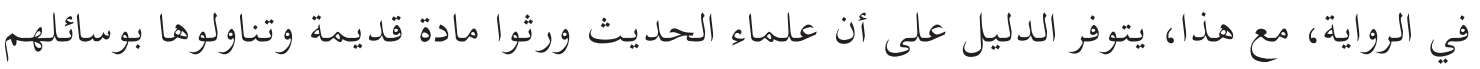

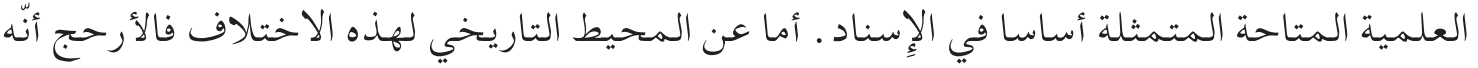

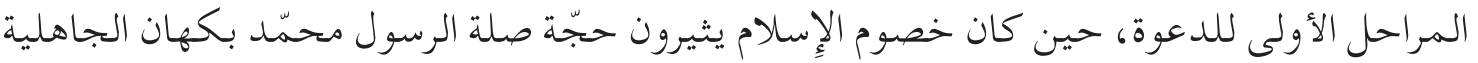

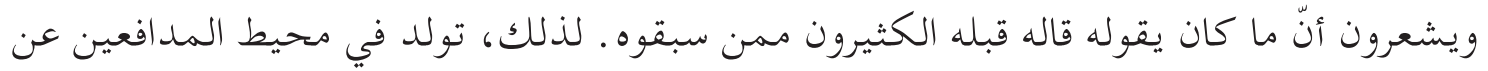

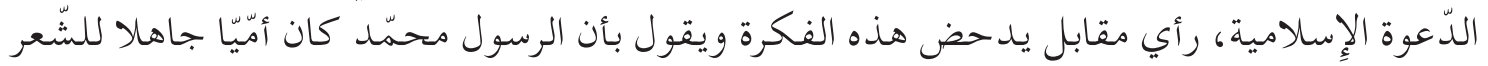
وأصناف القول، ورسخت الفكرة الدفاعية في دائرة العقيدة .

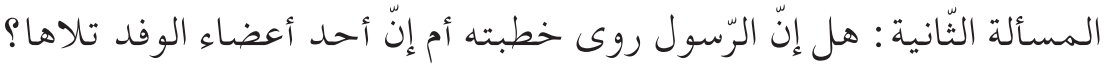

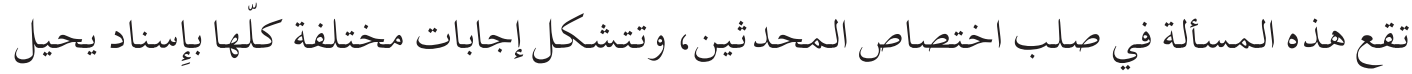
إلى زمن قريب من مرحلة الدعوة.

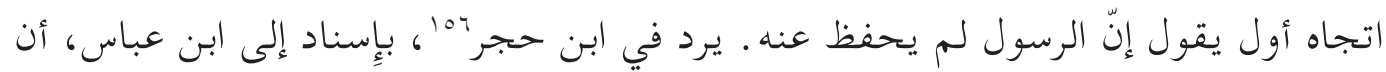

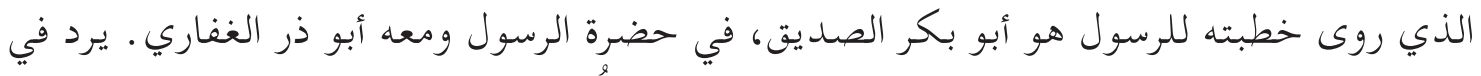

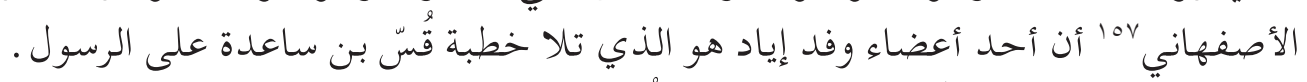

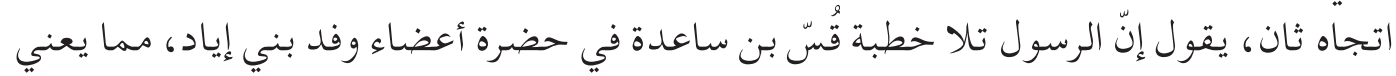

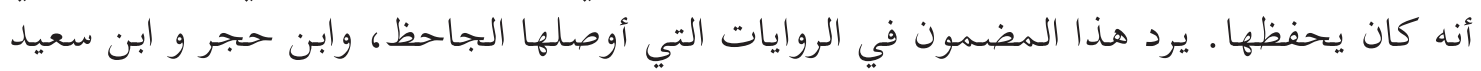

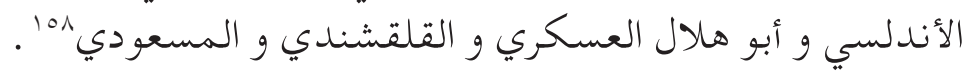

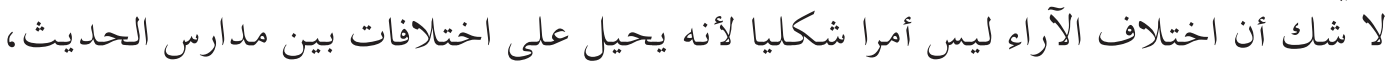

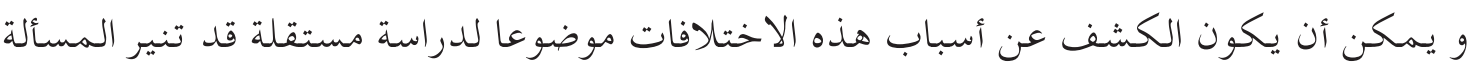

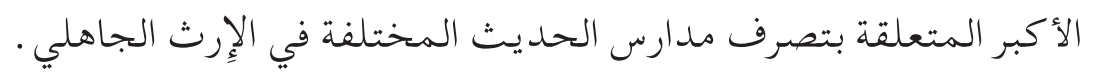

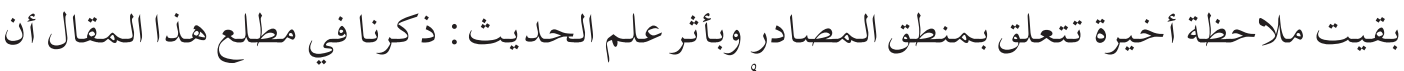

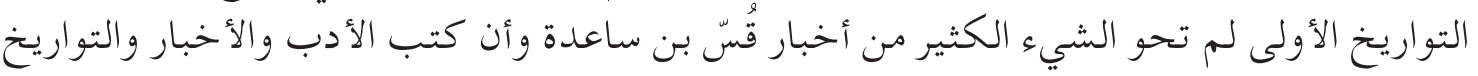

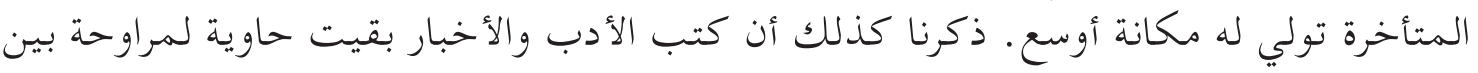

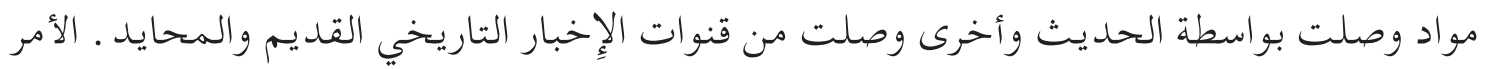

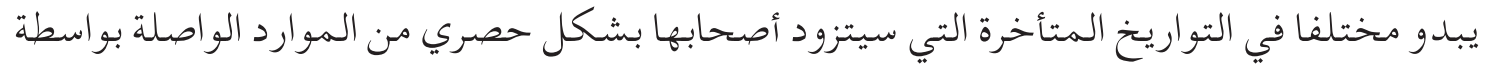

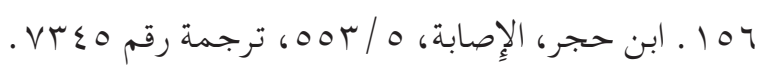

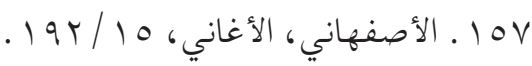

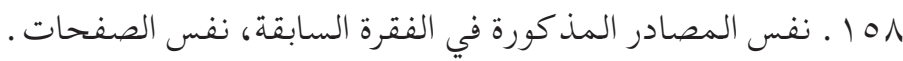




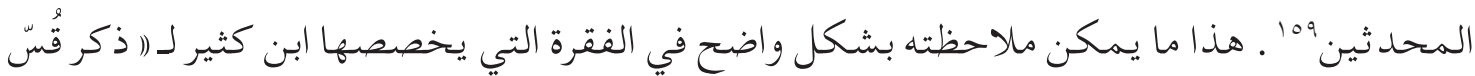

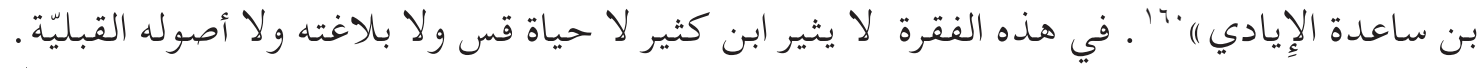

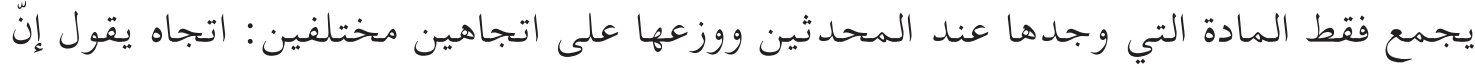

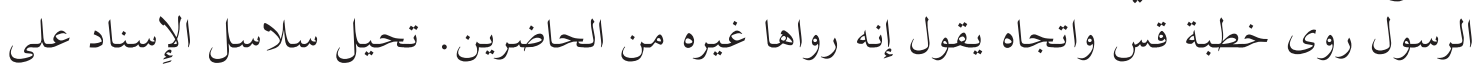

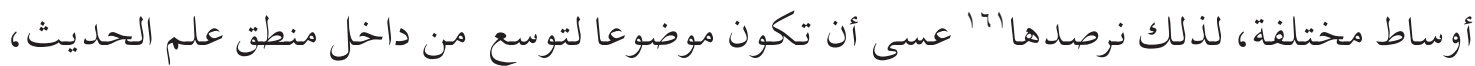

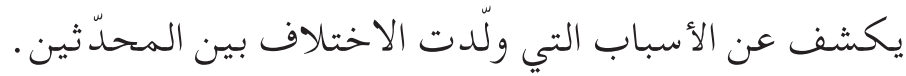

وه 1 ـ عن العلاقة بين التاريخ وعلم الحديث انظر التأملات القيمة لعبد الله العروي في:

. Islam et histoire, Paris, Albin Michel, 1999

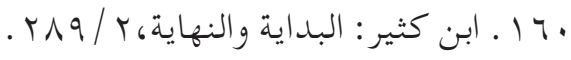

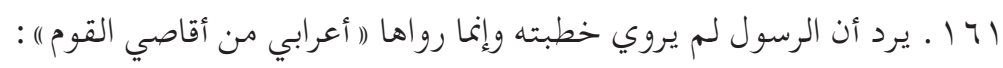

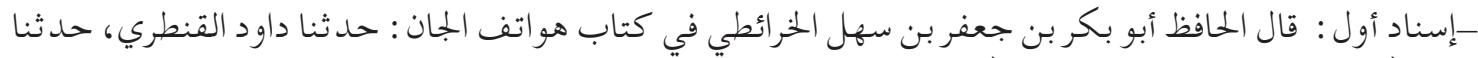

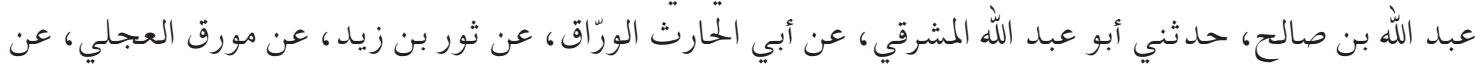

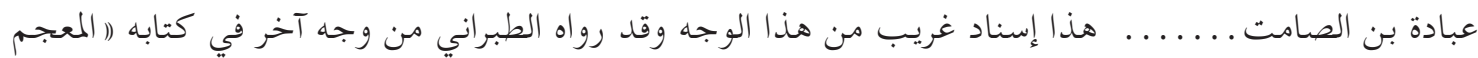
الكبير ")

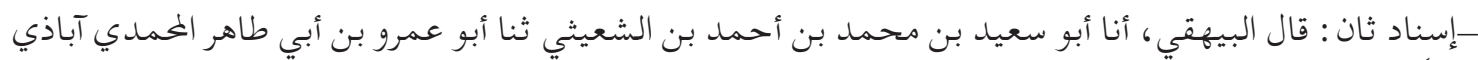

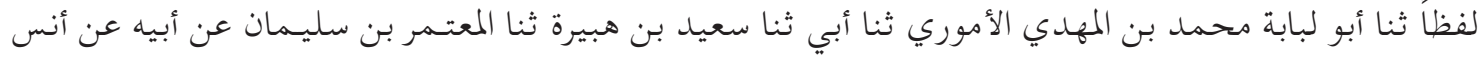

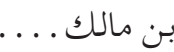

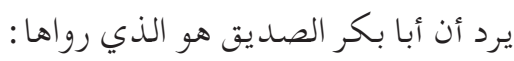

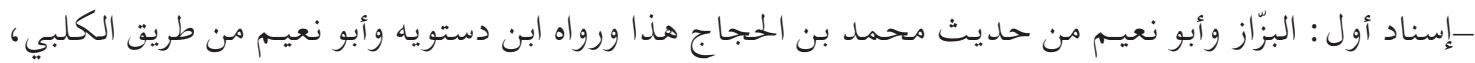

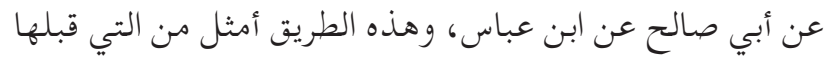

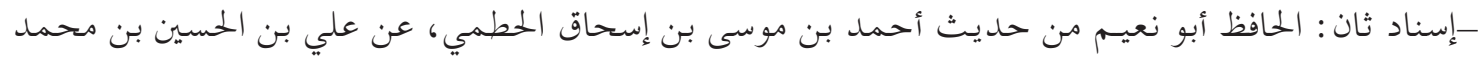

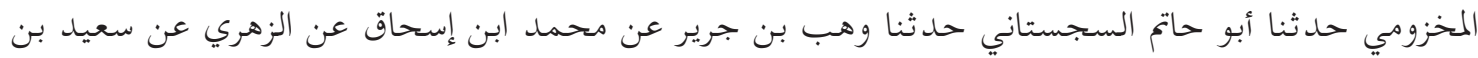
المسيب عن ابن عباس مان.

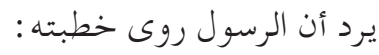

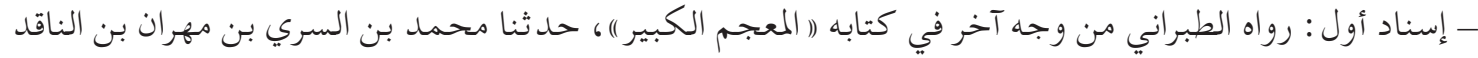

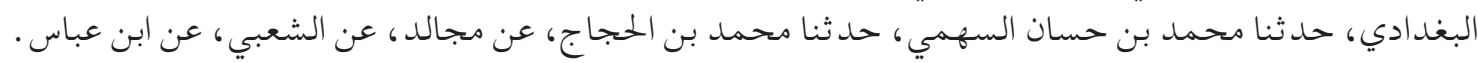

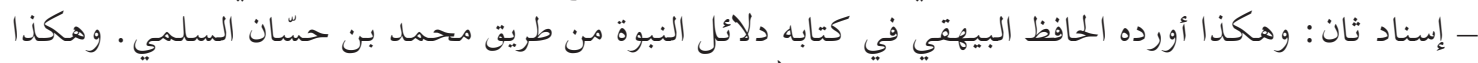

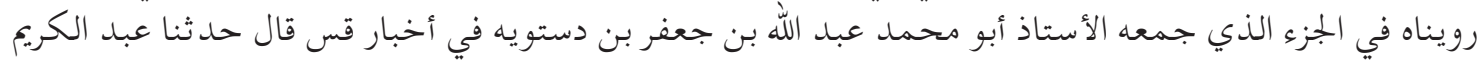

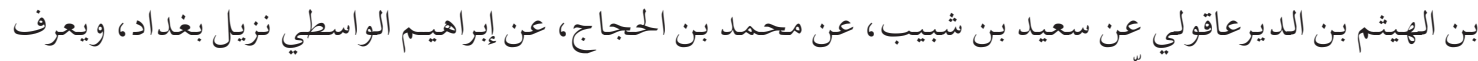

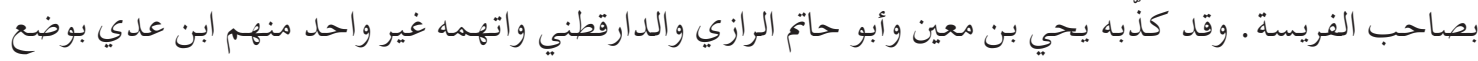




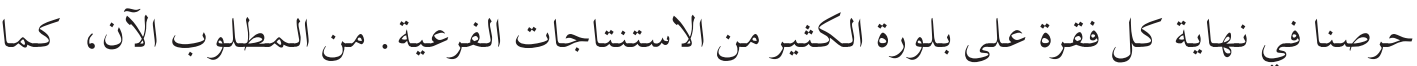

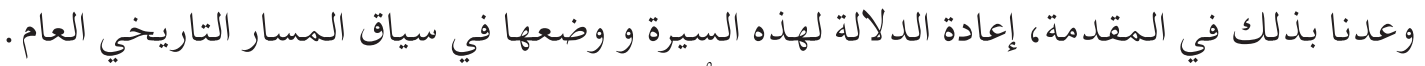

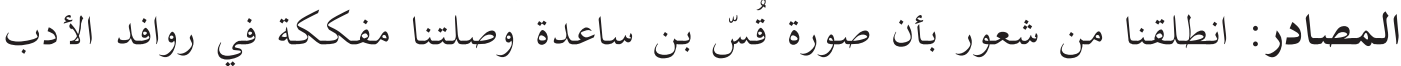

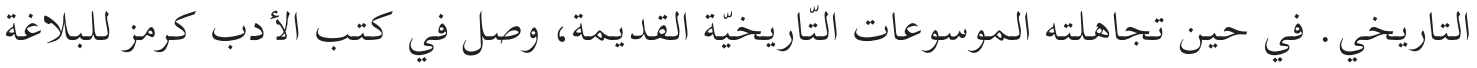

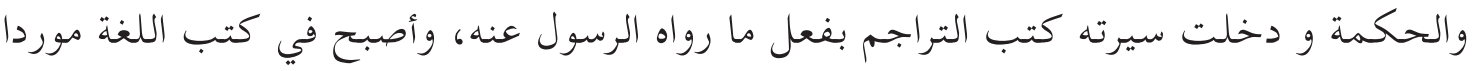

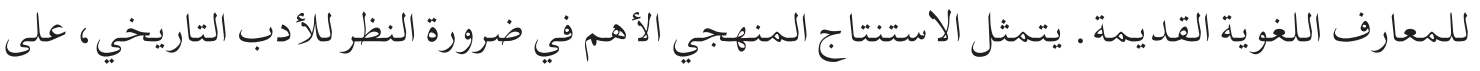

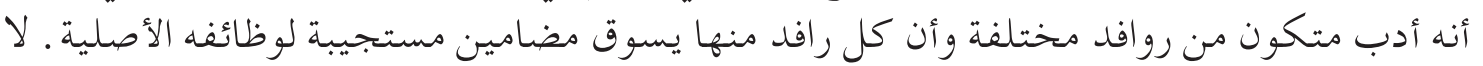

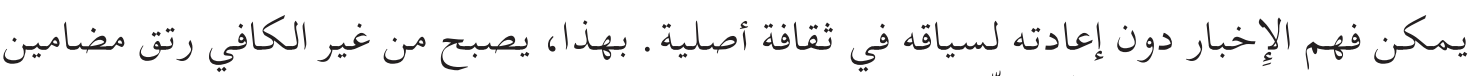

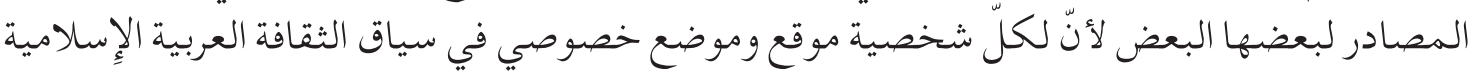

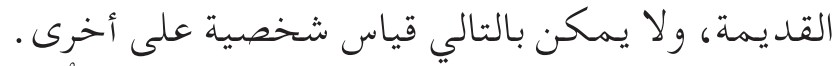

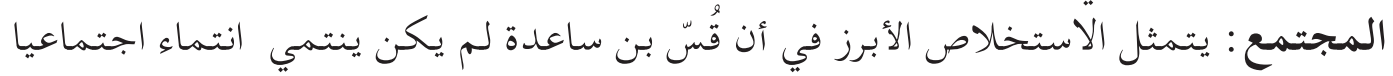

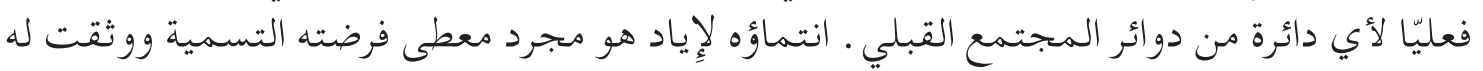

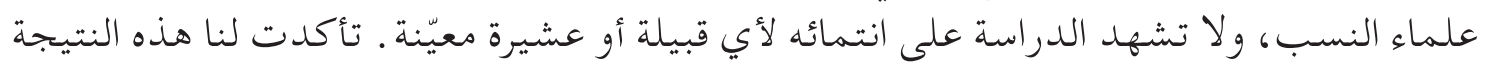

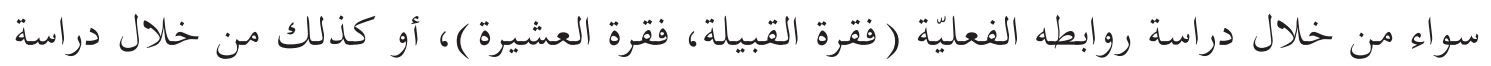

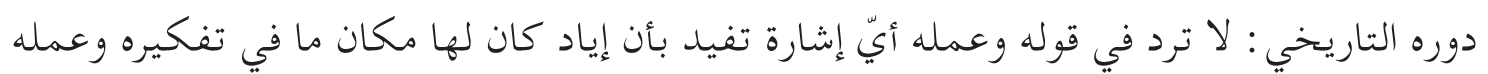

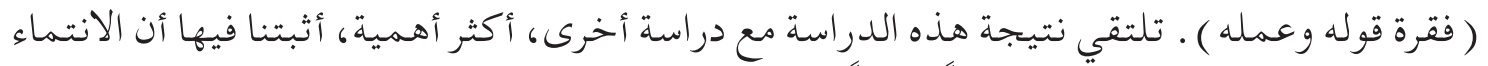

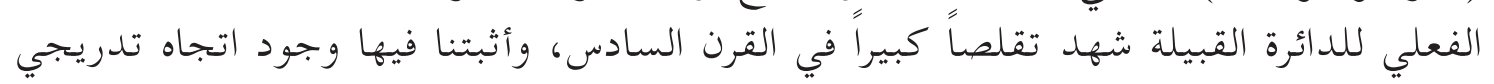

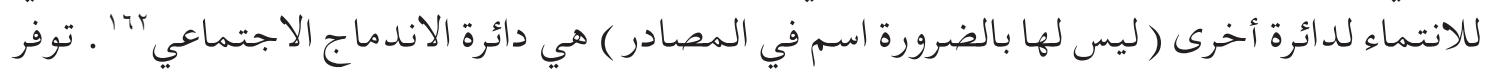

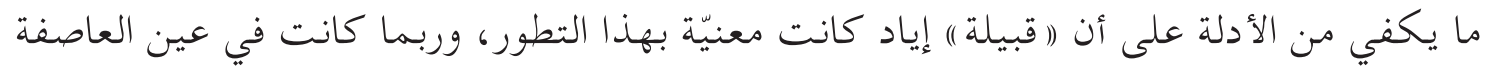

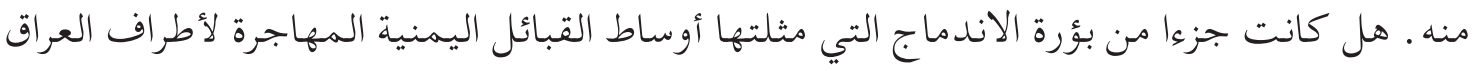

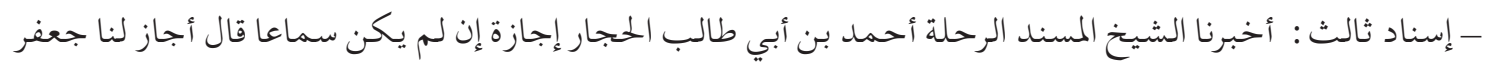

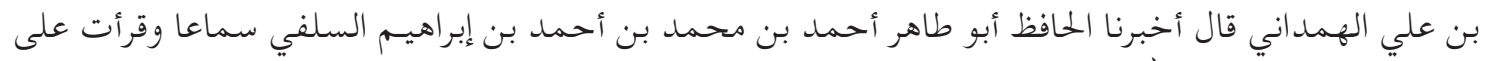

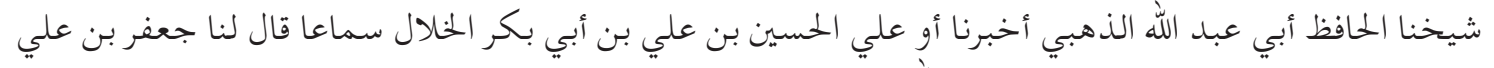

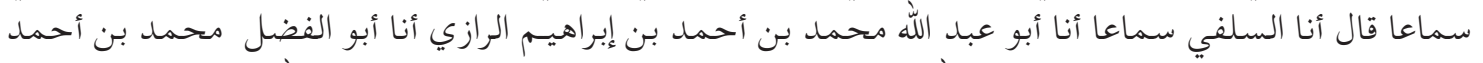

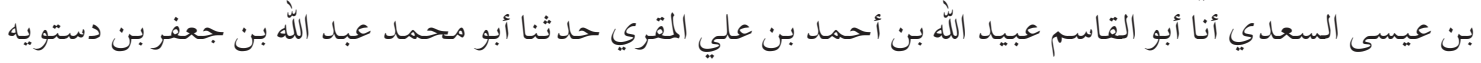

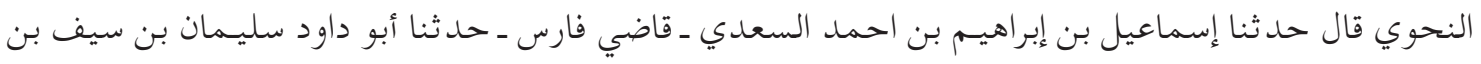

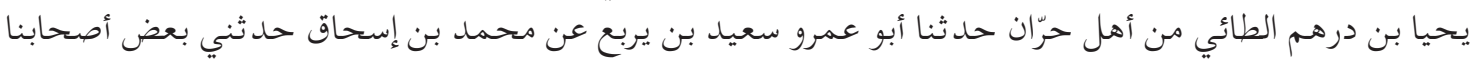

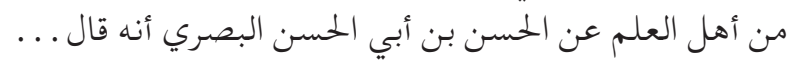
با 1 ـ محمد سعيد، النسب والقرابة، الخلاصة. 
وبلاد الشام؟ أمر محتمل، لأننا نراه جلياً في الاندماج الحادث في يثرب مثلاً، لكن يتطلب إثباته

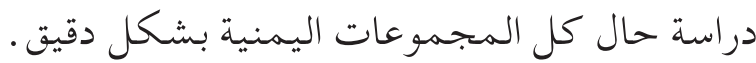

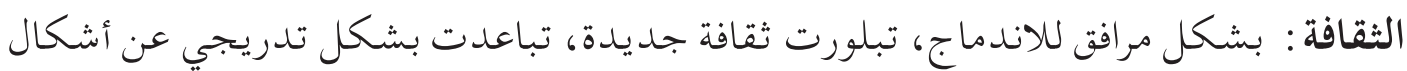

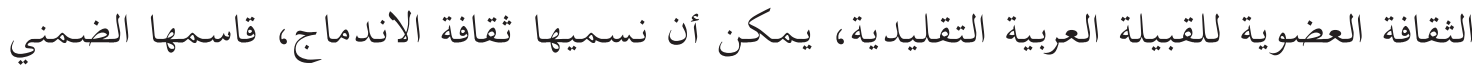

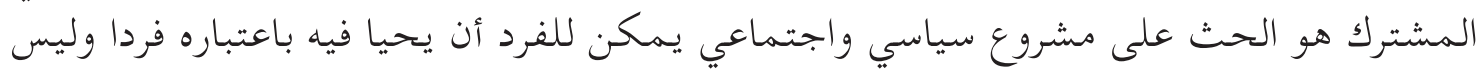

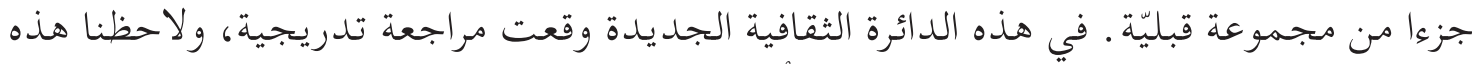

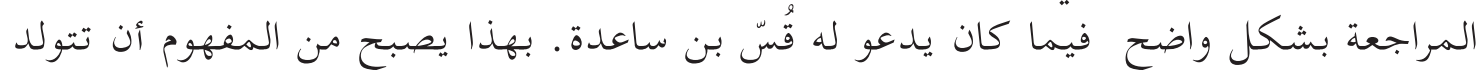

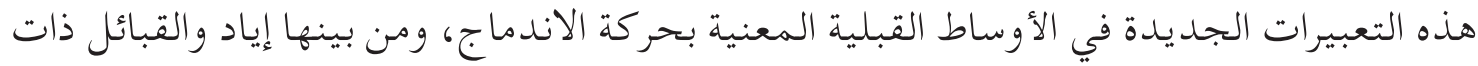

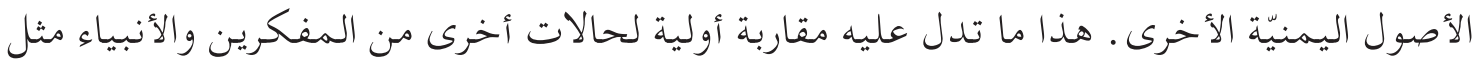

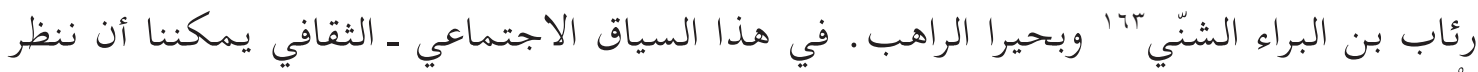

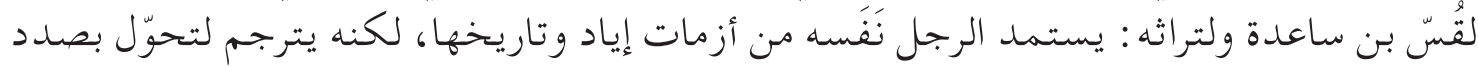

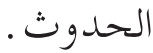

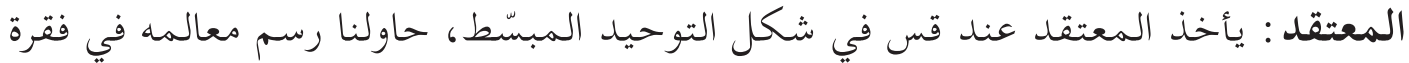

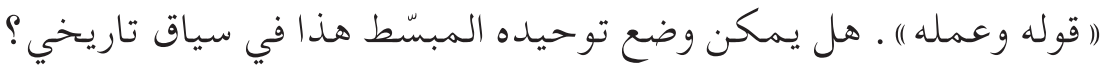

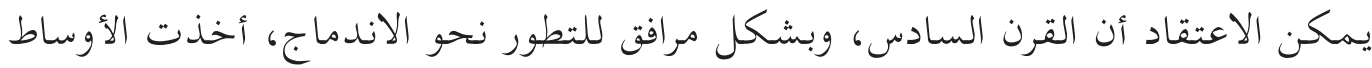

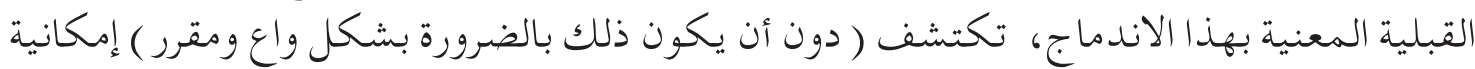

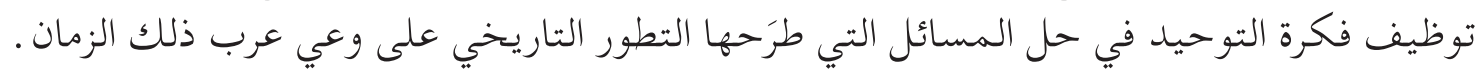

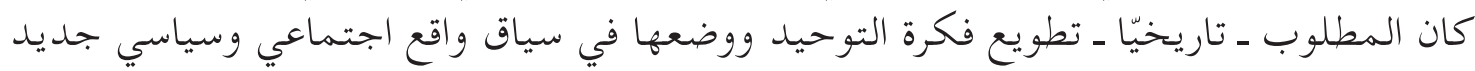

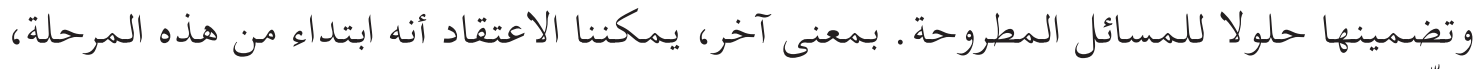

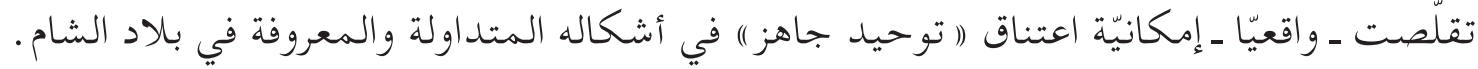

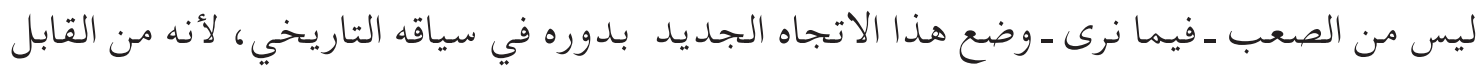

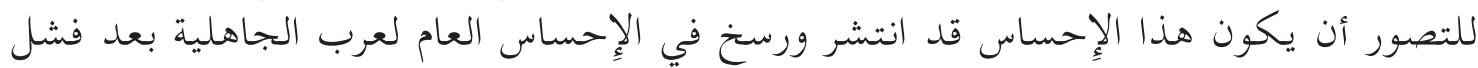

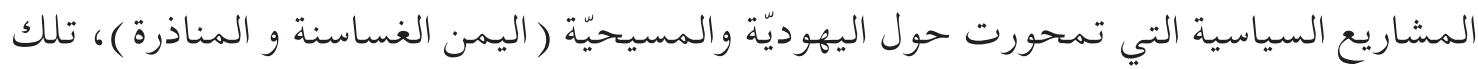

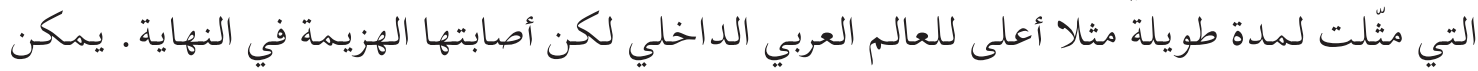

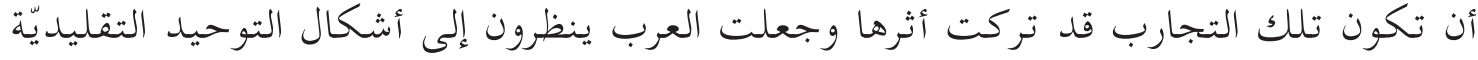

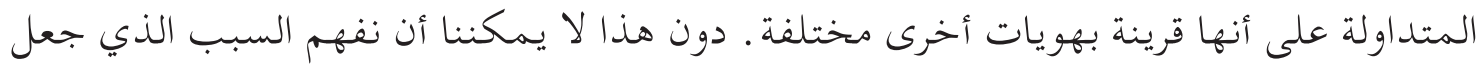

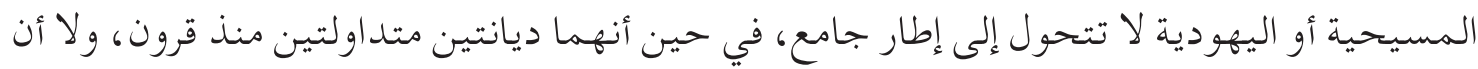

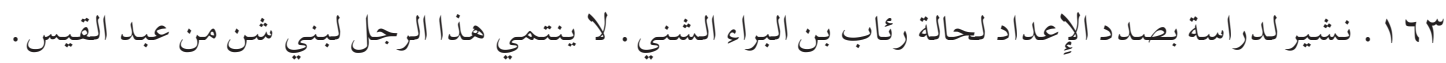

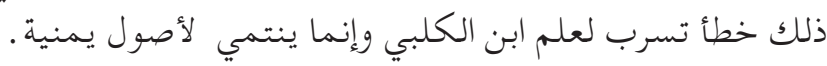


نفهم أسباب نشأة شكل من التوحيد الخصوصي هو الإِسلام، ولا أن نفهم حدوث ذلك في القرن السابع.

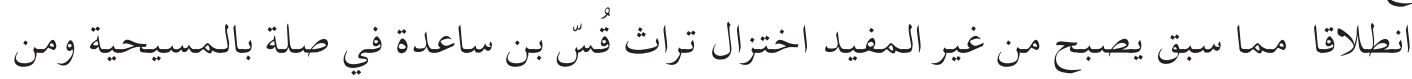

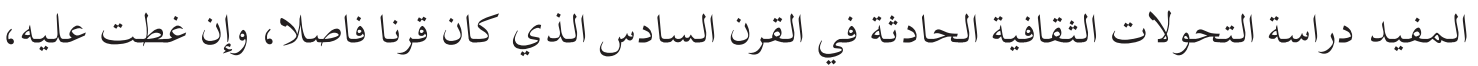

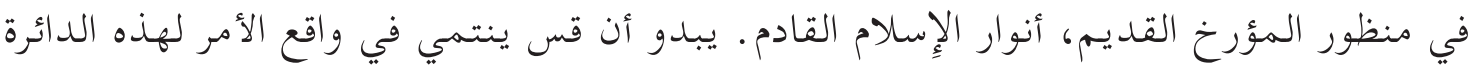

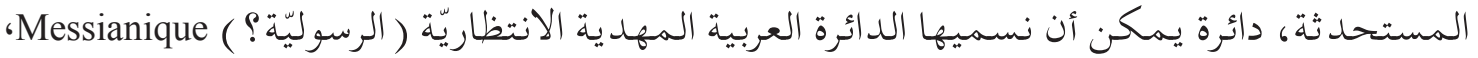

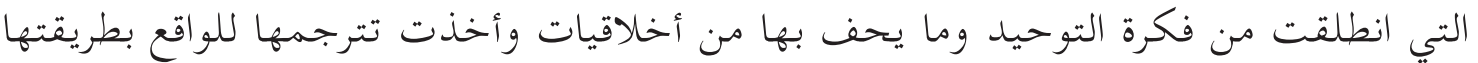

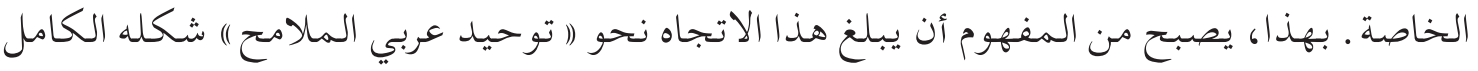

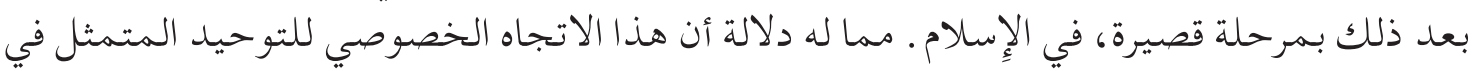

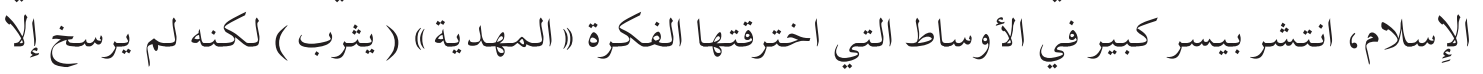

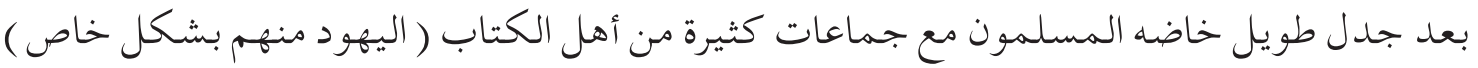

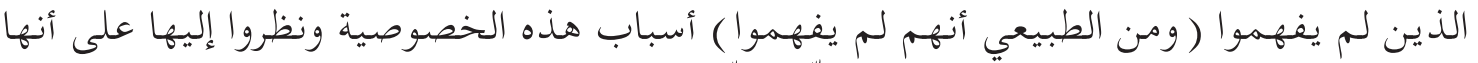

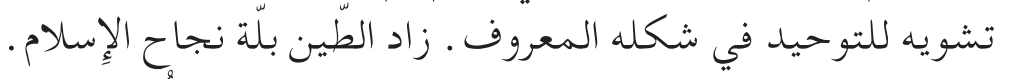

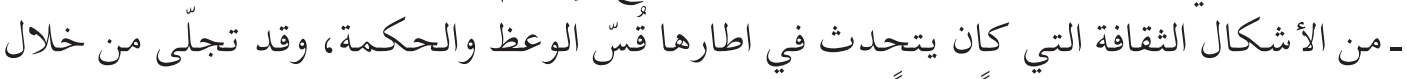

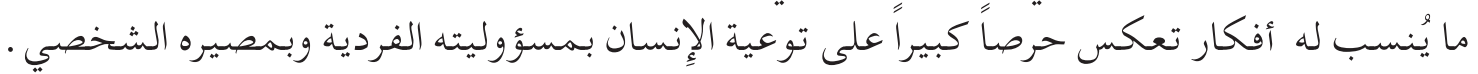

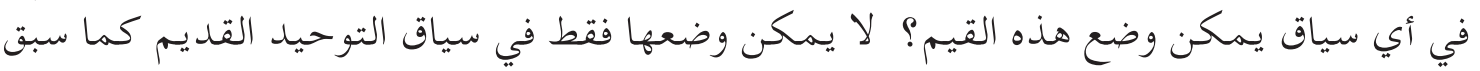

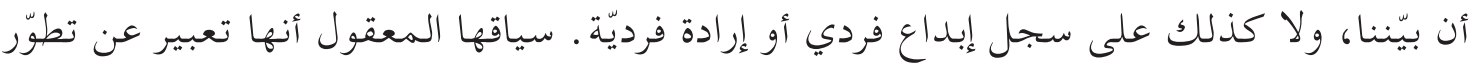

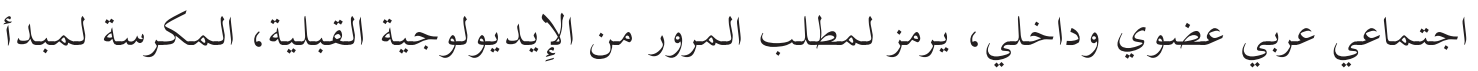

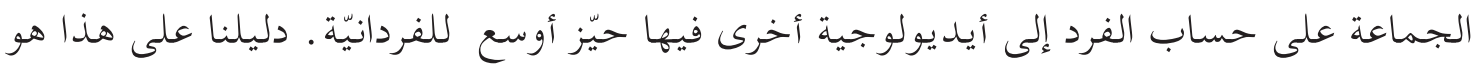

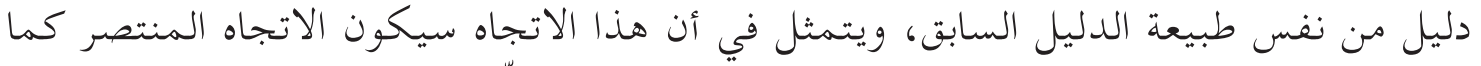

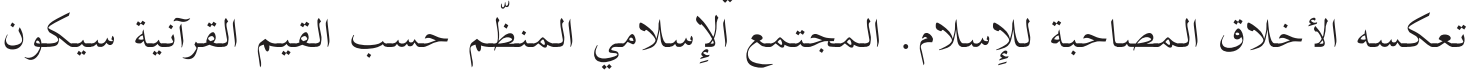

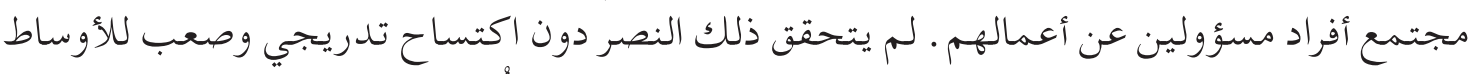

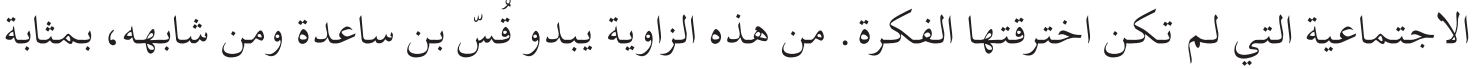

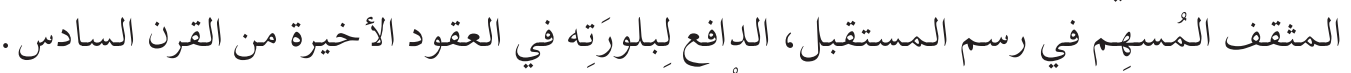

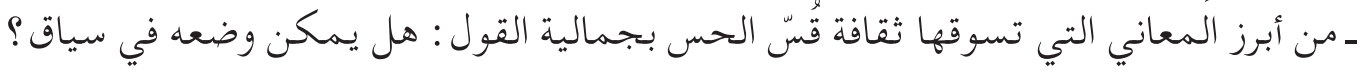

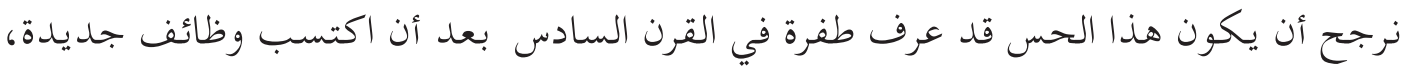

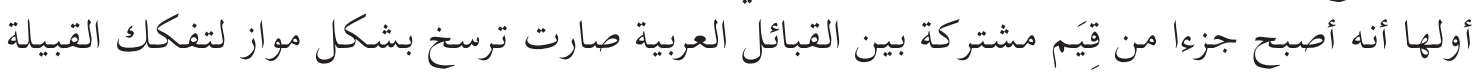

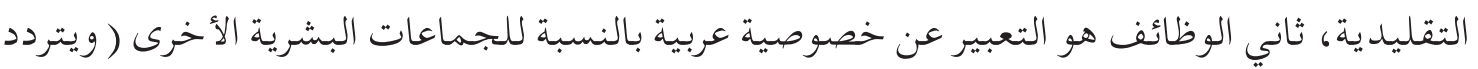

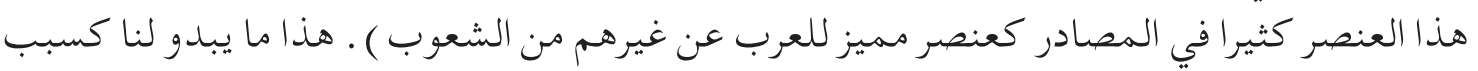

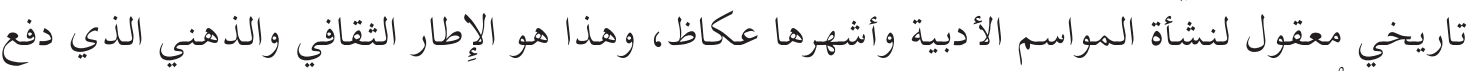

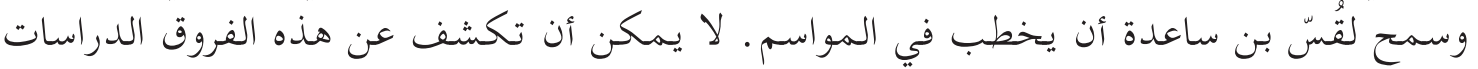




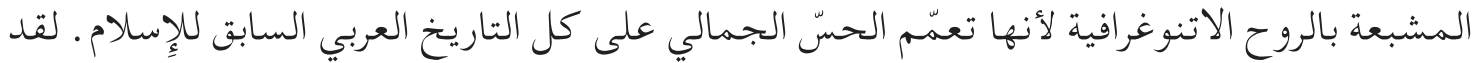

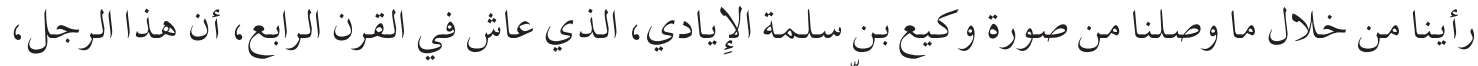

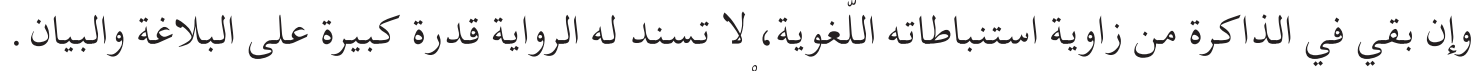

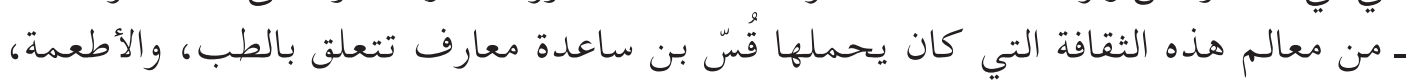

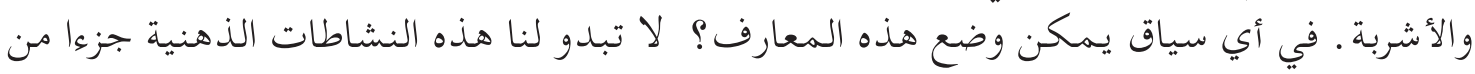

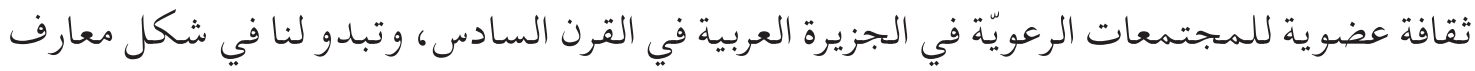

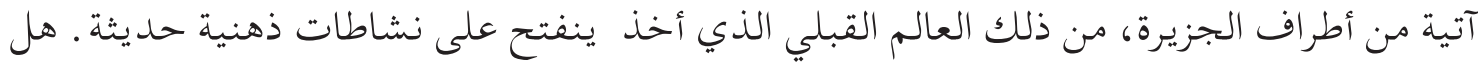

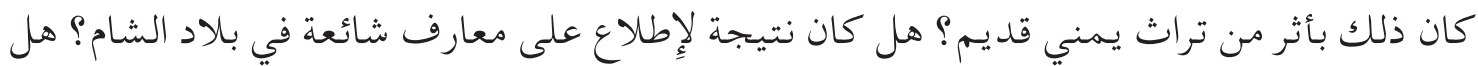

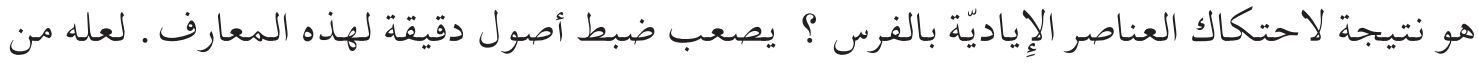

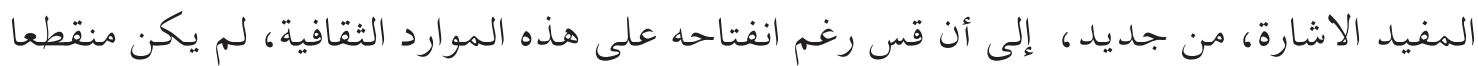

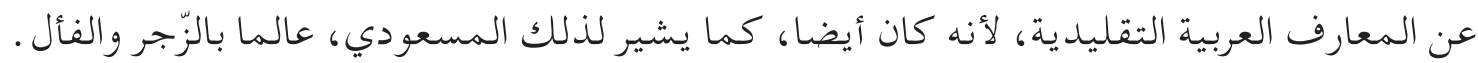
يبدو قس في شكل واسطة ثقافية بين عو الم مختلفة .

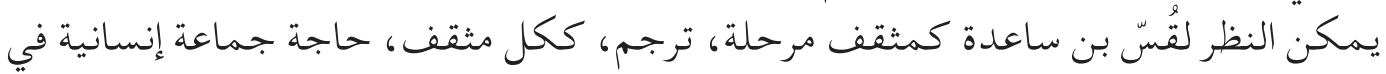

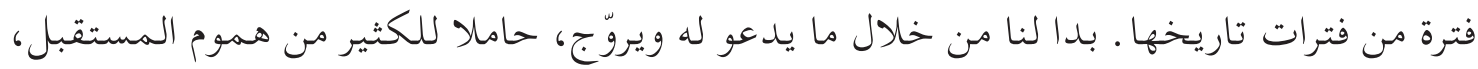

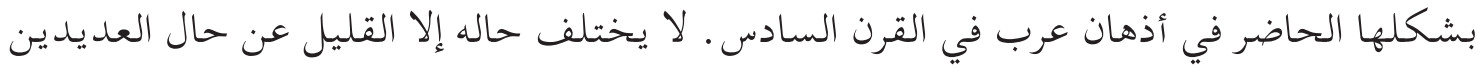

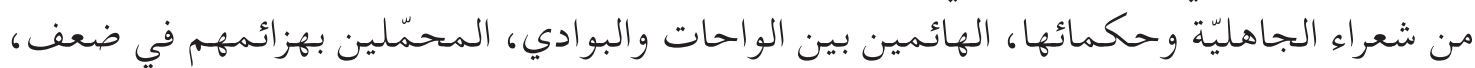

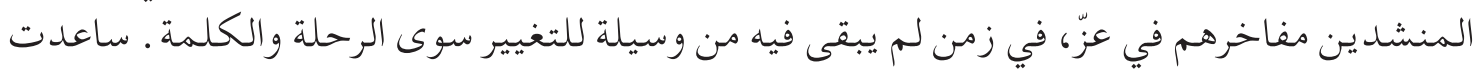

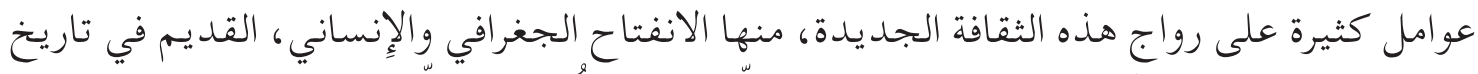

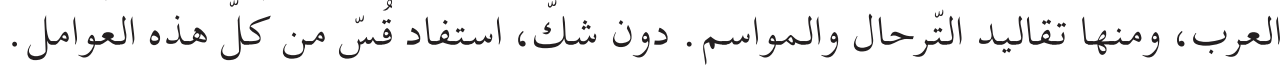

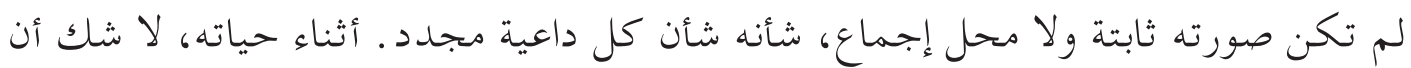

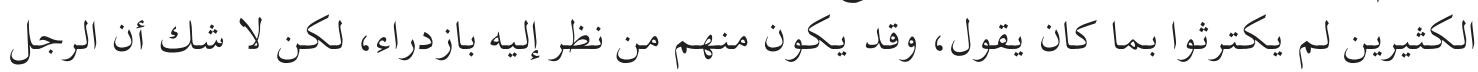

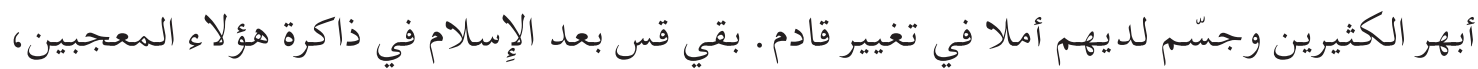

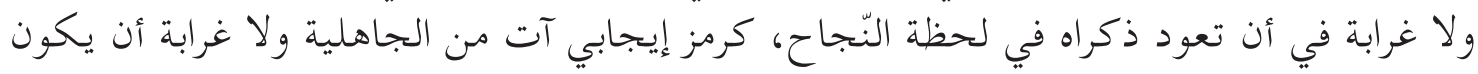
موعودا له بالبعث يوم القيامة، ((أمّة وحلده )) . 